\title{
Interaction between primary alveolar macrophages and primary alveolar type II cells under basal conditions and after lipopolysaccharide or quartz exposure
}

\author{
Rania S. Kanj \\ West Virginia University
}

Follow this and additional works at: https://researchrepository.wvu.edu/etd

\footnotetext{
Recommended Citation

Kanj, Rania S., "Interaction between primary alveolar macrophages and primary alveolar type II cells under basal conditions and after lipopolysaccharide or quartz exposure" (2004). Graduate Theses,

Dissertations, and Problem Reports. 2079.

https://researchrepository.wvu.edu/etd/2079

This Dissertation is protected by copyright and/or related rights. It has been brought to you by the The Research Repository @ WVU with permission from the rights-holder(s). You are free to use this Dissertation in any way that is permitted by the copyright and related rights legislation that applies to your use. For other uses you must obtain permission from the rights-holder(s) directly, unless additional rights are indicated by a Creative Commons license in the record and/ or on the work itself. This Dissertation has been accepted for inclusion in WVU Graduate Theses, Dissertations, and Problem Reports collection by an authorized administrator of The Research Repository @ WVU. For more information, please contact researchrepository@mail.wvu.edu.
} 


\title{
Interaction Between Primary Alveolar Macrophages And Primary Alveolar Type II Cells Under Basal Conditions And After Lipopolysaccharide Or Quartz Exposure
}

\author{
Rania S. Kanj \\ Dissertation submitted to the \\ School of Medicine \\ at West Virginia University \\ in partial fulfillment of the requirements \\ for the degree of \\ Doctor of Philosophy \\ in \\ Physiology and Pharmacology \\ Vincent Castranova, Ph.D., Chair \\ David Frazer, Ph.D. \\ Ping Lee, Ph.D. \\ Robert R. Mercer, Ph.D. \\ Yongyut Rojanasakul, Ph.D. \\ Department of Physiology and Pharmacology \\ Morgantown, West Virginia \\ 2004
}

Keywords: alveolar type II cells (TII), alveolar macrophages, co-culture, lipopolysaccharide (LPS), quartz (or silica), tumor necrosis factor-alpha (TNF- $\alpha$ ), macrophage inflammatory protein-2 (MIP-2), interleukin-1 beta (IL-1 $\beta$ ), interleukin-6 (IL-6), nitric oxide (NO*), surfactant 


\title{
ABSTRACT \\ Interaction Between Primary Alveolar Macrophages And Primary Alveolar Type II Cells Under Basal Conditions And After Lipopolysaccharide Or Quartz Exposure
}

\begin{abstract}
Rania S. Kanj
Evidence suggests that hyperproduction of reactive oxidants and inflammatory mediators plays a critical role in adverse pulmonary responses to silica or lipopolysaccharide (LPS). The main objective of this study was to contribute to advancing the understanding of the role of AM's and type II (TII) cells in the induction of pulmonary inflammation and injury in response to silica and LPS, and improve our understanding of the interaction between AM's and TII cells which would occur in vivo. To reach this objective, three aims were put forth. 1) Determine the relative responsiveness of primary rat AM's, primary rat TII cells and RLE-6TN, a rat TII cell line to silica and LPS under comparable conditions. 2) Determine if AM/TII intercellular interactions exist and under what conditions they can be demonstrated. 3) Attempt to identify the mediator(s) responsible for this interaction. The following findings were made: 1) although AM's were generally found to release more inflammatory mediators than TII cells following LPS or silica exposures, primary TII cells clearly produced significant levels of mediators which could be capable of contributing considerably to lung inflammation and injury. 2) Since the RLE-6TN cell line responses to LPS and silica exposures were generally considerably less intense and required higher doses of stimulant than those measured in primary TII cells, RLE-6TN cells may not be a good substitute for primary TII cells in studying the pulmonary epithelium. 3) LPS was more potent than silica in inducing inflammatory cytokines from the three cell types. However, silica was found to be as potent as LPS or even slightly more potent as an inducer of cellular oxidants, especially from primary TII cells. 4) Surfactant appears to be an inhibitory mediator released from TII cells and acts on AM's. 5) Basal transwell co-culture conditions are better than mixed co-culture conditions to study AM/TII cell interactions since the inhibitory effect of the surfactant in the transwell co-culture is minimized. 6) Oxidants, TNF-alpha, IL-1beta, prostaglandins and leukotrienes, probably do not directly affect the AM/TII intercellular interaction; instead, they (and especially TNF-alpha) appear to indirectly modulate the complex pathways of the AM/TII communication.
\end{abstract}




\section{Acknowledgement}

I am extremely grateful for everyone who helped make my experience as a graduate student very educationally rich, productive, and enjoyable at the same time. The first person I would like to thank is my advisor, Dr. Vincent Castranova who, despite his many other duties and obligations, was extremely generous in providing me with all the time I needed. He is a true mentor. I would also like to thank Dr. Jihee Kang who contributed excellent ideas and feedback to my work. In addition, Mark Barger, Linda Bowman, Dr. Stephen Leonard, Dr. Dale Porter, and Victor Robinson have all been very gracious in helping me throughout my years in graduate school. Also, I will not forget the help of my graduate committee, namely Dr. David Frazer, Dr. Ping Lee, Dr. Robert Mercer, and Dr. Yongyut Rojanasakul, for providing very instructive feedback. In addition, I would not have been able to do it without my friends' help. They were my son's family during my most hectic times. And finally, and most importantly, I can not thank my family enough, my son Sami, my daughter Serene, and especially my husband, Ghassan. Ghassan was the one who patiently listened to my frustrations when the experiments did not work. He never hesitated to give me, or our kids, what little free time he had. 


\section{Table of Contents}

Abstract. ........................ ii

Acknowledgements..............................

List of Tables..................................... $\quad \mathrm{v}$

List of Figures................................ vi

List of Abbreviations............................. $\mathrm{x}$

Introduction..................................... 1

Materials \& Methods................................ 16

Results........................................ 36

Discussion .................................... 100

References.................................... 120 


\section{List of Tables}

No.

$\underline{\text { Page }}$

1 LPS-induced cytotoxicity in primary rat AM's measured by LDH release into the medium and the percentage of cell nuclei stained with trypan blue

2 LPS-induced cytotoxicity in primary rat TII cells measured by LDH release into the medium and the percentage of cell nuclei stained with trypan blue

3 LPS-induced cytotoxicity in RLE-6TN cells measured by LDH release into the medium and the percentage of cell nuclei stained with trypan blue

4 Silica-induced cytotoxicity in primary rat AM's measured by LDH release into the medium and the percentage of cell nuclei with trypan blue

5 Silica-induced cytotoxicity in primary rat TII cells measured by LDH release into the medium and the percentage of cell nuclei stained with trypan blue

6 Silica-induced cytotoxicity in RLE-6TN cells measured by LDH release into the medium and the percentage of cell nuclei stained with trypan blue 


\section{List of Figures}

No.

Page

$1 \quad$ Coulter tracing for AM's 29

2 Coulter tracing for TII cells 30

$3 \quad$ Fluorescent microscopy of TII cells stained with phosphine 3R 31

$4 \quad$ TEM of a TII cell $\quad 32$

$5 \quad$ TEM of a cell sample following TII isolation and purification by adherence 33

$6 \quad$ Micrograph of AM and TII cells in mixed co-culture $\quad 34$

$7 \quad$ A 12-well plate transwell with dimensions 35

$8 \quad$ TPRO from primary rat AM's upon LPS exposure 46

$9 \quad$ TPRO from primary rat TII cells upon LPS exposure $\quad 48$

10 TPRO from RLE-6TN cells upon LPS exposure 50

11 TPRO from primary rat AM's upon silica exposure 52

12 TPRO from primary rat TII cells upon silica exposure $\quad 54$

13 TPRO from RLE-6TN cells upon silica exposure 56

14 Exposure- induced NO release from the 3 cell types upon LPS exposure 57

15 Exposure- induced TNF- $\alpha$ release from the 3 rat alveolar cell types upon 58 LPS exposure

16 Exposure- induced TNF- $\alpha$ release from the 3 rat alveolar cell types upon 59 silica exposure

17 Exposure- induced MIP-2 release from the 3 rat alveolar cell types upon $\quad 60$ LPS exposure

18 Exposure- induced MIP-2 release from the 3 rat alveolar cell types upon $\quad 61$ silica exposure 
19 Exposure- induced IL-1 $\beta$ release from the 3 rat alveolar cell types upon LPS exposure

20 Exposure- induced IL-1 $\beta$ release from the 3 rat alveolar cell types upon silica exposure

21 Exposure- induced IL-6 release from the 3 rat alveolar cell types upon LPS exposure

22 Exposure- induced IL-6 release from the 3 rat alveolar cell types upon silica exposure

23 Exposure- induced $\mathrm{O}_{2}^{-\cdot}$ release from AM's upon silica exposure

24 Exposure- induced $\mathrm{O}_{2}^{-\bullet}$ release from TII cells upon silica exposure

25 Exposure- induced $\mathrm{O}_{2}^{-}$release from RLE-6TN cells upon silica exposure

26 Exposure- induced ROS release from AM's upon LPS exposure

27 Confocal microscopy of AM's with dihydroethydium dye upon LPS exposure

28 Exposure- induced ROS release from the AM's upon silica exposure

29 Confocal microscopy of AM's with dihydroethydium dye upon silica exposure

30 Exposure- induced ROS release from primary rat TII cells upon silica exposure

31 Confocal microscopy of primary rat TII cells with dihydroethydium dye upon silica exposure

32 TNF- $\alpha$ release in mixed AM/TII co-culture, transwell AM/TII co-culture, 75 or AM and TII monocultures

33 TNF- $\alpha$ potentiation (value in the mixed co-culture system minus value of 76 the sum of the separate cell cultures) upon adding fibrinogen to AM/TII basal mixed co-culture

34 MIP-2 release in mixed AM/TII co-culture, transwell AM/TII co-culture, or AM and TII monocultures 
35 MIP-2 potentiation (value in the mixed co-culture system minus value of the sum of the separate cell cultures) upon adding fibrinogen to AM/TII basal mixed co-culture

36 NO release in mixed AM/TII co-culture, transwell AM/TII co-culture, or AM and TII monocultures

37 NO potentiation (value in the mixed co-culture system minus value of the sum of the separate cell cultures) upon adding fibrinogen to AM/TII basal mixed co-culture

38 IL-1 $\beta$ release in mixed AM/TII co-culture, transwell AM/TII co-culture, or AM and TII monocultures

39 IL-1 $\beta$ potentiation (value in the mixed co-culture system minus value of the sum of the separate cell cultures) upon adding fibrinogen to AM/TII basal mixed co-culture

40 IL-6 release in mixed AM/TII co-culture, transwell AM/TII co-culture, or AM and TII monocultures

41 IL-6 potentiation (value in the mixed co-culture system minus value of the sum of the separate cell cultures) upon adding fibrinogen to AM/TII basal mixed co-culture

42 TNF- $\alpha$ and MIP-2 levels from AM's cultured on the transwell insert relative to AM's cultured on the plate surface

43A Diffusion of TNF- $\alpha$ through the transwell

43B Diffusion of survanta through the transwell

44 TNF- $\alpha$ and MIP-2 potentiation upon adding fibrinogen to RAW/TII mixed co-culture

45A Fold difference in TNF- $\alpha$ release upon adding different inhibitors to $\mathrm{AM} / \mathrm{TII}$ basal transwell co-culture versus fold difference without adding any inhibitor

45B Fold difference in MIP-2 release upon adding different inhibitors to $\mathrm{AM} / \mathrm{TII}$ basal transwell co-culture versus fold difference without adding any inhibitor

46A TNF- $\alpha$ levels relative to control upon adding different mediators to AM monocultures 
46B MIP-2 levels relative to control upon adding different mediators to AM's monocultures

47A TNF- $\alpha$ levels relative to control upon adding different mediators to TII monocultures

47B MIP-2 levels relative to control upon adding different mediators to TII monocultures

48 MIP-2 levels relative to control upon adding different mediator combinations 95 to AM monocultures

49 TNF- $\alpha$ and MIP-2 from AM's cultured in normal medium (control) and 96 from AM's cultured in an 18-hour TII-conditioned medium

50 TNF- $\alpha$ and MIP-2 from TII cells cultured in normal medium (control) and from TII cells cultured in an 18-hour AM-conditioned medium

51A MIP-2 from TII cells cultured in normal medium (control) and from TII cells cultured in an 18-hour AM-conditioned medium, and in an 18-hour AM-conditioned medium plus anti-TNF- $\alpha$

51B TNF- $\alpha$ and MIP-2 from TII cells cultured in normal medium (control) and 99 from TII cells cultured in an 18-hour AM-conditioned medium, and in an 18-hour AM-conditioned medium plus anti-IL-1 $\beta$ 


\section{List of Abbreviations}

Alveolar type II: TII

Alveolar macrophage: AM

Polymorphonuclear leukocyte: PMN

Lipopolysaccharide: LPS

Tumor necrosis factor-alpha: TNF- $\alpha$

Macrophage inflammatory protein-2: MIP-2

Interleukin-1-beta: IL1- $\beta$

Interleukin-6: IL-6

Nitric oxide: NO

Inducible nitric oxide synthase: iNOS

Reactive oxygen species: ROS

Superoxide anion: $\mathrm{O}_{2}{ }^{-}$

Bronchoalveolar lavage: BAL

Lactate dehydrogenase: LDH

Total protein: TPRO

Phosphate-buffered saline: PBS

Fetal bovine serum: FBS 


\section{$\underline{\text { Introduction }}$}

The lung can be susceptible to disease because of its direct contact with the outside environment. Alveolar macrophages (AM's) phagocytize and clear inhaled microbes and particles, therefore, playing an important role in lung defense. However, when exposed to high dust burdens, AM's secrete reactive products and cytokines, which can cause lung inflammation and damage. This excessive inflammation is believed to play a critical role in occupational lung diseases, such as silicosis and toxic pneumonitis (Zhang et al., 2000). Recent evidence suggests that alveolar type II epithelial cells (TII) may also contribute to lung inflammation (Blau et al., 1994; Crippen et al., 1995; Finkelstein et al., 1997).

Main objective: Contribute to advancing the understanding of the role of AM's and TII cells in the induction of pulmonary inflammation and injury in response to silica and LPS, and improve our understanding of the interaction between AM's and TII cells which would occur in vivo.

Aim 1: Determine the relative responsiveness of AM's, primary TII cells and a TII cell line to silica and LPS under comparable conditions.

Aim 2: Determine if intercellular interactions exist and under what conditions they can be demonstrated.

Aim 3: Attempt to identify the mediator(s) responsible for this interaction.

The three cell types used in this study are primary rat AM's, primary rat TII cells, and RLE-6TN, a rat TII cell line.

Alveolar macrophages (AM's): 
AM's are the alveolar derivatives of blood monocytes and are located at the air/tissue interface within the surfactant lining of the alveolar region. These cells are the first line of defense against outside contaminants and invaders (Lohmann-Matthes et al., 1994). AM's are the phagocytes of the alveolar region. With the variety of membrane receptors they possess (Johansson et al., 1997), AM's are able to bind a variety of particles and compounds including LPS (Martin, 1999) and silica (Kobzik, 1995; Iyer et al., 1996). Once binding has occurred, AM's engulf inhaled particles and migrate up the mucociliary escalator or enter the lymphatic ducts to be cleared from the lung (Stober and McClellan, 1997). Phagocytizing AM's can produce reactive oxygen species through a respiratory or oxidative burst that directly contributes to killing microorganisms (Johnson, 1978). AM's are also capable of directly killing viruses by producing interferon (Hahon and Castranova, 1989). When incapable of killing foreign organisms by themselves, AM's recruit more phagocytic cells to the area by releasing chemokines, such as macrophageinflammatory protein-2 (MIP-2), which acts to attract polymorphonuclear leukocytes (PMN's), monocytes and other cells from the pulmonary capillaries to the alveolar airspaces (Nielson et al., 1995).

Type II alveolar epithelial cells (TII):

TII cells comprise about $4 \%$ of the alveolar epithelial surface, but they constitute approximately $60 \%$ of the alveolar epithelial cell population in number (Crapo et al., 1983). For a long time, they have been known to synthesize, store and secrete the surfactant material lining the alveoli. Such production and release of surfactant has been demonstrated using both in vivo (Askin and Kuhn, 1971) and in vitro (Mason et al., 1980; Miles et al., 1988) model systems. Surfactant consists mainly of phospholipids (Sanders 
and Longmore, 1975) and proteins, and its role in decreasing surface tension and, thus, decreasing the work required to inflate the lungs was demonstrated by Clements (1957 and 1977). However, other roles have also been attributed to surfactant, such as enhancement of bacterial phagocytosis and killing by AM's (O'Neil et al., 1984) and decreasing the cytotoxicity of inhaled particles by coating their surface (Wallace et al., 1985). TII cells are also an important site for xenobiotic metabolism and are strategically located in close contact with both the pulmonary air and blood phases. In effect, TII cells are capable of detoxifying or toxifying foreign substances, since they're rich in endoplasmic reticulum (ER) which exhibits P-450-dependent monooxygenase activity (Castranova et al., 1988). TII cells have another important role in the lungs, which is to maximize gas exchange. This is accomplished by the transcellular transport of $\mathrm{Na}^{+}$and $\mathrm{H}_{2} \mathrm{O}$, thereby, keeping the alveoli dry and preventing edema (Jones et al., 1983). Indeed, TII monolayers in culture exhibit "Dome" formation as $\mathrm{Na}^{+}$is passively transported into the cell at the luminol side and actively transported to the blood at the basolateral side, and water follows (Mason et al., 1982: Castranova et al., 1988). Regeneration of the alveolar epithelium is another important role played by TII cells in the lungs, where TII cells have the ability to proliferate following injury (Panos et al., 1990) and dedifferentiate into TI cells to repair the alveolar epithelium (Leslie et al., 1985). TII cells also contribute to protecting the lung from oxidant injury since they have specialized pathways for the uptake of antioxidants, such as vitamin $\mathrm{C}$ and taurine (Castranova et al., 1983; Banks et al., 1989), which help in resistance to oxidant damage. Like AM's, TII cells play a major antiviral role by producing interferon upon viral exposure (Hahon and Castranova, 1989). They can also produce NO" ROS and cytokines in response to 
different stimulants (Punjabi et al., 1994) and, thus, contribute to cell recruitment in response to an inflammatory agent and microbial killing (Crippen et al., 1995).

$\underline{\text { Rat lung epithelial-T-antigen negative (RLE-6TN) cells: }}$

Rat lung epithelial-T-antigen negative, or RLE-6TN cells were derived from alveolar TII cells by Kevin Driscoll et al. (1995a). Like primary TII cells, RLE-6TN cells contain lamellar bodies for surfactant storage, and they have the ability to produce cytokines, NO and other ROS when stimulated (Stringer and Kobzik, 1998; Driscoll et al., 2001). Unlike primary TII cells, RLE-6TN cells maintain their morphology and the ability to produce surfactant even after a long time in culture (few days).

Of major importance to lung pathology are two main airborne contaminants: silica and lipopolysaccharide (LPS).

Silica:

Silica or silicon dioxide $\left(\mathrm{SiO}_{2}\right)$, mostly in its quartz crystalline form, is a common mineral found in most rocks around us (Peters, 1986). Being highly fibrogenic and biologically toxic, it can bind to membrane receptors on target cells, including AM's (through their surface scavenger receptors) and TII cells (Kobzik et al., 1995; Iyer et al., 1996). Silica can directly cause cellular toxicity. It can also initiate an inflammatory response that could include increased oxidant production and proinflammatory mediator secretion as a result of nuclear transcription factor- $\kappa \mathrm{B}(\mathrm{NF}-\kappa \mathrm{B})$ activation (Kang et al., 2000; Vallyathan and Shi, 1997) in target and recruited cells. Such events could eventually lead to lung injury and fibrosis (Castranova, 1998 and 2000 a) or even lung cancer (Driscoll et al., 1997). Cleavage of crystalline silica, as in rock drilling, tunneling and sand blasting, results in the generation of the highly toxic silicon-based radicals ( $\mathrm{Si}$. 
and Si-O ). Upon inhalation, these surface radicals can then interact with water molecules, producing the highly toxic hydroxyl radicals $\left(\mathrm{OH}^{*}\right)$ and other radicals (Vallyathan et al., 1988; Castranova, 1994). Many industry-related occupations have a relatively high silica exposures. In fact, among the highest exposure occupations are rock drilling, sandblasting, tunneling, silica flour mill operations, stone grinding, and ceramic making (Castranova and Vallyathan, 2000 b). Through either acute or chronic exposures, silica particles can result in biopersistence in the lung alveolar spaces (Stober and McClellan, 1997), leading to cell damage, release of inflammatory mediators, and in many cases lung fibrosis or silicosis (Donaldson and Tran, 2002). Among the symptoms accompanying acute silicosis are pulmonary edema, interstitial inflammation and alveolitis, alveolar epithelial hypertrophy and hyperplasia, and increased surfactant phospholipid release by alveolar TII cells (Driscoll et al., 1990; Porter et al., 2001). With chronic silicosis, silicotic nodules, characterized by collagen deposited in a spiral pattern, can be recognized mainly in the upper lung lobes (Castranova and Vallyathan, $2000 \mathrm{~b}$ ).

\section{$\underline{\text { LPS: }}$}

LPS is a lipid-carbohydrate component of gram-negative bacterial endotoxin, which is the bacteria's outer cell membrane complex. Endotoxin, including the active LPS component, can be associated with indoor or outdoor organic dust particles, if humidity and temperature conditions are favorable to microbial growth. Endotoxin exposure can occur in agricultural settings, such as silo unloading or poultry processing, as well as in textile industry, wastewater treatment and other occupations (Burrell, 1997).

One of the many ways through which LPS can be recognized by target cells is by binding with an LPS binding protein (LPB) to CD 14 cellular membrane receptors (Martin, 
1999). Other LPS cell membrane receptors are Toll Like Receptors (TLR) (Chen et al., 2002). This recognition is capable of triggering a cell signaling cascade that usually involves modification of $\mathrm{G}$ proteins and activation of protein kinase $\mathrm{C}$ in a calciumdependent fashion. Although recognition and intracellular signaling can differ with target cell and type of receptor LPS binds to, the result of this binding with most target cells is usually the stimulus for an inflammatory response (Blau et al., 1994), which could be associated with many inflammatory lung diseases. The cellular signaling cascade triggered by LPS binding to target cells is thought to induce synthesis of inducible nitric oxide synthase (iNOS), activation of NAD(P) oxidase, activation of cyclooxygenase-2 $(\mathrm{COX}-2)$, and activation of many transcription regulatory factors like NF- $\mathrm{BB}$ (Calvano et

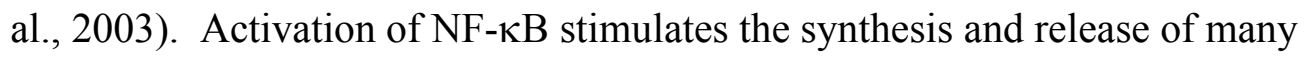
inflammatory mediators, such as the pro-inflammatory cytokines TNF- $\alpha$, IL- $\beta$, and IL-6, ( Chen et al., 1995; Christman et al., 1998). Acute exposure to LPS is associated with diseases such as byssinosis, acute respiratory distress syndrome (ARDS) and sepsis, whereas a chronic exposure is associated with lung diseases, such as asthma, chronic bronchitis, chronic obstructive pulmonary disease (COPD), chronic byssinosis and other serious lung diseases. A typical LPS lung inflammation is usually accompanied by fever, chills, cough, and tightness of chest caused by pulmonary edema. Also, symptoms of chronic LPS exposure are typical for a chronic lung inflammation and include peribronchial and perivascular lymphatic aggregates, alveolar and airway changes including alveolar enlargement, airway wall thickening and mucus cell metaplasia (Vernooy et al., 2002). LPS exposure is also characterized by a elevated PMN number in the bronchoalveolar lavage (BAL) fluid. 
The end-points which were investigated in the present study were reactive oxygen species (ROS), nitric oxide (NO ), tumor necrosis factor- $\alpha(\mathrm{TNF}-\alpha)$, macrophage inflammatory protein-2 (MIP-2), interleukin-1 $\beta$ (IL-1 $\beta$ ), and interleukin-6 (IL-6).

\section{$\underline{\text { Reactive oxygen species (ROS): }}$}

Although oxygen is vital for energy generation by mammalian cells via aerobic oxidative metabolism, some oxygen metabolites can be very toxic to cells if produced excessively. Such oxygen metabolites are termed reactive oxygen species or reactive oxygen intermediates (ROS or ROI) and include the hydroxyl radical $\left(\mathrm{OH}^{\cdot}\right)$, superoxide radical $\left(\mathrm{O}_{2}^{-\cdot}\right)$ and hydrogen peroxide $\left(\mathrm{H}_{2} \mathrm{O}_{2}\right)$ (Castranova, 1998). In resting cells, mitochondrial "leakage" is one of the main sources for ROS, whereby $2-4 \%$ of the oxygen consumed for ATP production is reduced to $\mathrm{O}_{2}^{-{ }^{-}}$rather than water (Chen and Castranova, 2003). This "leakage" could increase upon cellular activation, since cellular respiration increases. Another main site for ROS formation is the membrane-bound multisubunit enzyme complex termed NADPH oxidase. This enzyme is usually dormant in resting cells and is activated upon complexation of cytosolic and membrane subunits as a result of cell binding to a stimulus (Babior, 1999). When cells like AM's and TII bind toxic substances like LPS or silica, high levels of ROS are generated that can overwhelm the cells' antioxidant capacity and cause oxidative stress. ROS are generally very unstable and highly reactive. They can cause direct cell damage by oxidizing lipids (Dalal et al., 1990), proteins, carbohydrates, and DNA which confer to ROS a microbicidal and tumoricidal role (Johnston, 1978). They can also cause indirect cell and /or tissue damage by inducing cellular production of other pro-inflammatory mediators, such as TNF- $\alpha$, MIP-2, IL-1 $\beta$, IL-6 and other mediators regulated by NF- $\kappa B$ and AP-1 nuclear 
transcription factors (Comhair and Erzurum, 2002). The main set of chemical reactions leading to ROS generation include the following (Chen and Castranova, 2004):

$$
\begin{aligned}
& 2 \mathrm{O}_{2}+\mathrm{NADPH}+\mathrm{H}^{+} \underset{\text { oxidase }}{\stackrel{\mathrm{NADPH}}{\rightarrow}} 2 \mathrm{O}_{2}^{-\cdot}+\mathrm{NADP}^{+}+2 \mathrm{H}^{+} \\
& 2 \mathrm{O}_{2}^{-\cdot}+2 \mathrm{H}^{+} \rightarrow \mathrm{H}_{2} \mathrm{O}_{2}+\mathrm{O}_{2} \\
& \mathrm{O}_{2}^{-\cdot}+\mathrm{H}_{2} \mathrm{O}_{2} \rightarrow \mathrm{OH}^{-}+\mathrm{OH}^{-}+\mathrm{O}_{2}
\end{aligned}
$$

Substantial evidence exists that support the ability of AM's and TII cells to release ROS upon stimulation. Indeed macrophage release of ROS upon LPS (Chandel et al., 2000) and silica (Kang et al., 2000) exposure has been suggested to be a mediator in NF- $\mathrm{KB}$ activation and TNF- $\alpha$ and MIP-2 release (Barrett et al., 1999 b). Also, TII cells release of ROS has been detected in a murine TII cell line (MLE-15) upon silica exposure using an oxidant sensitive dye (Barrett et al., 1999 a). ROS production has also been detected in a rat TII cell line (RLE-6TN) (Driscoll et al., 2001).

\section{Nitric oxide (NO):}

Similar to ROS, reactive nitrogen species (RNS), such as nitric oxide (NO ), nitrite $\left(\mathrm{NO}_{2}\right)$ and peroxynitrite $\left(\mathrm{ONOO}^{-}\right)$, are vital for normal cell functioning but can be toxic if produced excessively by stimulated cells. Also similar to ROS, RNS are generally very unstable and highly reactive. They can cause direct or indirect cell and /or tissue damage by inducing both oxidizing and/or nitrating cellular damage (Jorens et al., 1993). RNS may also induce production of other pro-inflammatory mediators, such as TNF- $\alpha$, MIP-2, IL-1 $\beta$, IL-6 and other mediators regulated by activator protein-1 (AP-1) and nuclear

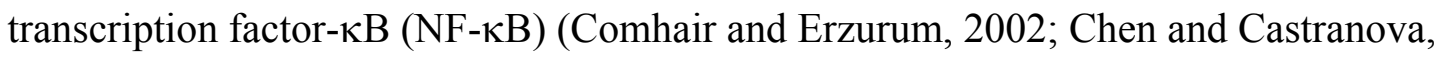
2003). NO gas is released as a by-product of the conversion of L-arginine to L-citruline, 
catalyzed by the enzyme nitric oxide synthase (NOS). Of the three types of the cytosolic NOS enzymes, the calcium independent NOS II (or iNOS), which is the inducible form, has been the one mostly linked with reactive stress caused by overactivation of the enzyme upon its synthesis following cell stimulation (Comhair and Erzurum, 2002; Jorens et al., 1993). The main chemical reactions of NO resulting in the generating of reactive oxidants include (Castranova, 1998):

$\mathrm{NO}+\mathrm{O}_{2}^{-\cdot} \rightarrow \mathrm{OONO}^{-}$

$\mathrm{OONO}^{-}+\mathrm{H}^{+} \rightarrow \mathrm{HOONO} \rightarrow \mathrm{OH}^{\cdot}+\mathrm{NO}_{2}$

NO release from primary AM's following in vivo silica exposure has been shown to increase significantly compared to control. In contrast, NO release from AM's following in vitro silica exposure was not significantly enhanced (Huffman et al., 1998). Also, mRNA for iNOS significantly increased in AM's following intratracheal (IT) instillation of silica (Castranova, 1998). Whereas silica exposure seems to require the intercellular communication found in vivo to induce NO synthesis from AM's, LPS has been shown to induce both NO and iNOS mRNA synthesis in macrophages following both in vivo (Blackford et al., 1994) and in vitro (Punjabi et al., 1994; Rao et al., 1999) LPS exposure. As for TII cells, iNOS enzyme and mRNA release have been reported to be significantly increased following in vivo LPS (Toga et al., 2001) or silica (Porter et al., 2002 b) exposure.

\section{Cytokines and chemokines:}

Cytokines are multifunctional extracellular signaling polypeptide mediators of cell behavior and intercellular communication involved in maintaining a steady-state lung environment under resting conditions, but are also involved in many ways upon tissue 
injury (Kelley, 1990). Cytokines exert their action by binding to their specific surface receptors on target cells ( Christman et al., 1998) and triggering a cascade of intracellular events that could lead to diverse effects through activation of various transcription factors. Similar to ROS, an imbalance between anti and pro- inflammatory cytokines in favor of the latter could result in tissue inflammation and injury (Martin, 1999). Chemokines are chemotactic mediators that help recruit inflammatory cells like PMN's, monocytes, lymphocytes, and macrophages to sites of microbial or particle deposition (Driscoll et al., 1996 a).

Tumor necrosis factor-alpha (TNF- $\alpha$ ): TNF- $\alpha$ is a very important inflammatory cytokine synthesized as an early response mediator in cellular stimulation (Martin, 1999). It's a mediator in the recruitment and activation of inflammatory cells, cell proliferation, and extracellular matrix protein synthesis (Driscoll, 1995 and 1996 b). It can stimulate the production of other pro-inflammatory cytokines, such as MIP-2 (Driscoll et al., 1996 a; Barrett et al., 1999 a) and IL-6 (Crestani et al., 1994), and other mediators such as ROS and NO through the activation of NF-kB (Driscoll et al., 2001; Barrett et al., 1999 a), and/or other cellular components. Primary AM's have been reported to produce increased TNF levels upon exposure to LPS or silica in vitro compared to control (Dubois et al., 1989). Also, TNF- $\alpha$ mRNA and protein has been shown to increase upon LPS or silica exposure compared to control in a murine macrophages cell line (RAW 264. 7) (Chen et al., 1995; Barrett et al., 1999 b). In addition, TII cells' TNF- $\alpha$ levels have been shown to increase following LPS (McRitchie et al., 2000; Haddad et al., 2002) or silica (Finkelstein et al., 1997) exposure. 
Interleukin-1beta (IL-1 $\beta$ ): IL-1 $\beta$ is an early response pro-inflammatory cytokine with many similar effects as TNF- $\alpha$, such as recruitment and activation of inflammatory cells, cell proliferation, extracellular matrix protein synthesis and induction of other proinflammatory cytokines. IL-1 secretion from AM's has been shown to increase following both in vivo and in vitro LPS exposures (Castranova et al., 2001), and following silica exposure (Driscoll et al., 1990). Also, TII cells have been shown to increase their IL-1 $\beta$ production following LPS (Haddad et al., 2002) or silica (Finkelstein et al., 1997) exposure.

Interleukin-6 (IL-6): IL-6 is a pro-inflammatory cytokine associated with fibrogenic activity (Lohmann-Matthes et al., 1994). IL-6 is produced by AM's following in vivo LPS exposure (Finkelstein et al., 1997). It is also produced by fetal alveolar TII cells following LPS exposure (Haddad et al., 2002) and by hyperplastic TII cells in the fibrotic human lung (Crestani et al., 1994). IL-6 synthesis can be mediated by other cytokines, such as TNF- $\alpha$ and IL-1 $\beta$ (Kelley, 1990; Crestani et al., 1994).

Macrophage inflammatory protein-2 (MIP-2): MIP-2 is a pro-inflammatory cytokine with chemotactic activity. It is involved in the recruitment of inflammatory cells (especially PMN's) to the site of tissue damage. MIP-2 also has a role in stimulating production of other inflammatory mediators, such as IL-1 $\beta$, TNF- $\alpha$ and histamine (Driscoll, 1994), and it has been reported to enhance bacterial phagocytosis and killing by AM's and PMN's (Standiford et al., 1996). MIP-2 secretion has been shown to increase in AM's following LPS (Shi et al., 1999) and silica (Driscoll et al., 1996 a; Barrett et al., 1999 b) exposures. In addition, MIP-2 mRNA and protein increased in TII cells after LPS or silica exposures in vivo and in vitro (Driscoll et al., 1996 a; Barrett et al., 1998 and 1999 a). 
Leukotrienes and prostaglandins: They are products of the breakdown of arachidonic acid (cell membrane component) by lipoxygenase (LO) and cyclo-oxygenase (CO) enzymes, respectively. Leukotrienes and prostaglandins are associated with increased inflammation, including chemotaxis and inflammatory cytokine production (Dubois et al., 1989). They have been shown to be released from AM's and macrophage cell lines upon both LPS and silica exposures (Dubois et al., 1989; Lohmann-Matthes et al., 1994; Chen et al., 1995).

Although there has been some studies looking at mediator release from AM's, TII and RLE-6TN cells individually upon LPS and silica exposures (Bissonnette et al., 1990, McRitchie et al., 2000 and Driscoll et al., 1996 a), there have been no studies, as far as we know, comparing the responses of the 3 cell types side-by-side, and only few studies looking at the interaction between primary AM's and primary TII cells in a co-culture system.

Importance of AM/TII intercellular interaction: Many studies have reported different results between in vitro and in vivo settings. For instance, Huffman et al. (1998) saw an increase in NO' released from AM's following an in vivo silica exposure but could not detect this increase upon exposing AM's to silica in vitro. Also, conditioned medium from BAL fluid (which includes mediators released from other alveolar cells including TII cells and polymorphonuclear leukocytes (PMN's)) following in vivo silica exposure was effective in making naïve AM's responsive to silica exposure in vitro. Hence, it is clear that intercellular interactions play a major role in cellular responses, such as $\mathrm{NO}$ production. Many more studies contribute to the evidence of the importance of AM/TII intercellular interactions. Those include a study by Miles et al. (1999) that has shown 
that surfactant (released from TII cells) inhibits LPS-induced NO production from AM's. And along the same lines, Rao et al. (2000) have reported that surfactant decreases LPS-induced TNF- $\alpha$ and IL-1 $\beta$ release from AM's. In addition, Blau et al. (1994) have shown that SP-A, an important surfactant protein, increases the production of colony stimulating factor (CSF) from primary AM's in vitro. Also, Leslie et al. (1985) have reported that AM's stimulate DNA synthesis in TII cells in vitro, and Standiford et al. (1990) have shown that conditioned media from LPS-stimulated AM's increased IL-8 mRNA in a human pulmonary TII-like epithelial cell line (A549). One more study that stresses the importance of intercellular interactions in cellular responses is by Crestani et al. (1994) who have shown that AM-conditioned media increases IL-6 production by TII in vitro under basal conditions.

As discussed above, evidence suggests that hyperproduction of reactive oxidants and inflammatory mediators plays a role in adverse pulmonary responses to silica or LPS. It is also clear that AM's and TII cells are involved in the production of these reactive and inflammatory products. However, no data were found that compared the release of several inflammatory mediators from AM's and TII cells under the same culture conditions, same exposures, and same cell concentrations. Also, no literature was found that compared the responsiveness of a type II cell line to primary TII cells under the same culture conditions and following exposure to LPS and silica. In addition, although $\mathrm{AM} / \mathrm{TII}$ cell interactions have been suggested to be very important in cellular responses, this interaction has not been studied in parallel under different interaction conditions (transwell and mixed co-culture) or different exposure conditions (basally, upon LPS exposure, or following silica exposure). And finally, there haven't been any studies that 
attempted different approaches to try to find specific mediators important in AM/TII intercellular communication.

Thus, the following questions remain unresolved:

1) What is the relative contribution of AM's and TII cells to the production of oxidants, chemokines, and cytokines in the lungs in response to LPS and silica? The answer to this question could help in revealing which cell type contributes more inflammatory mediators following lung injury caused by LPS or silica. It could also help reveal which agent is more potent at stimulating inflammatory mediators release and hence inducing more severe lung injury.

2) Is the responsiveness of RLE-6TN cell lines and primary TII cells similar? The answer to this question could determine if RLE-6TN cell line could be used in research in place of primary TII cells (since the TII isolation technique consumes animals, material, and time and is thus costly).

3) Does intercellular communication between AM's and TII cells alter the activity of AM's and/or TII cells? If so, what mediator(s) is/are involved in this intercellular communication? The answer to this question could help in designing in vitro experiments which more closely mimic in vivo situations.

To address these questions, this dissertation has the following objective and aims.

Main objective: Contribute to advancing the understanding of the role of AM's and TII cells in the induction of pulmonary inflammation and injury in response to silica and LPS, and improve our understanding of the interaction between AM's and TII cells which would occur in vivo. 
Aim 1: Determine the relative responsiveness of AM's, primary TII cells and RLE-6TN, a TII cell line to silica and LPS under comparable conditions.

Aim 2: Determine if intercellular interactions exist and under what conditions they can be demonstrated.

Aim 3: Attempt to identify the mediator(s) responsible for this interaction. 


\section{Materials and Methods}

Animal Model: All primary cells were collected from naive male Sprague-Dawley rats 250-300 g in weight (Hilltop Laboratory Animals, Scottsdale, PA). The animals were housed at the National Institute for Occupational Safety and Health animal facility, which is approved by AAALAC. Rats were housed under temperature and humidity controlled conditions under a 12 hour light/12 hour dark cycle and were allowed a week of acclimation before use in any experiment. They had free access to food and water at all times.

AM Isolation by BAL: Rats were anesthetized intraperitoneally with sodium pentobarbital ( $65 \mathrm{mg} / \mathrm{kg}$ body weight). The abdomen was cut vertically, the intestines pushed aside, and the renal artery cut to exsanguinate the animals. The diaphragm was carefully pierced to allow intrathoracic massaging of the lungs during the lavage procedure. The trachea was then exposed and a tiny whole was cut in it to allow an 18 gauge needle coated with plastic tubing (inside diameter $=0.040$ ") to be inserted inside, after which the trachea was tied with surgical thread to prevent any movement of the needle during the lavage procedure. While massaging the lungs, a solution of ice-cold calcium and magnesium-free phosphate buffered saline (PBS, 1x, $150 \mathrm{mM} \mathrm{NaCl}, 1.9$ mM KH${ }_{2} \mathrm{PO}_{4}, 9.35 \mathrm{mM} \mathrm{Na}_{2} \mathrm{PO}_{4}, \mathrm{pH}$ 7. 3-7. 5) was repetitively introduced and sucked back out of the lungs through a $10 \mathrm{ml}$ syringe attached to the tracheal canula. The first lavage consisted of only $2 \mathrm{ml} / 100 \mathrm{~g}$ body weight to allow any trapped air in the lungs to escape and prevent overinflation of the lungs. Subsequent lavage volumes were $8 \mathrm{ml}$ each, and the total volume of BAL fluid collected during this procedure was approximately $80 \mathrm{ml}$. This fluid was then centrifuged at $1000 \mathrm{~g}$ for 10 minutes, and after 
discarding the supernatant, the pellet was resuspended in 1 ml HAM's F-12 medium (pH 7. 07-7. 40)supplemented with $1 \mathrm{mM}$ glutamine, $100 \mathrm{U} / \mathrm{ml}$ of penicillin-streptomycin, and $10 \%$ FBS.

AM's were counted using an electronic cell counter (Coulter Multisizer II, Coulter Electronics, Hialeah, FL) equipped with a 256 channel cell sizer that counts cells according to their diameter. AM's were identified as having a diameter of $9-18 \mu \mathrm{m}$ (Castranova et al., 1990). The AM yield was $12 \pm 4$ million cells/rat (Figure 1: Coulter tracing), the purity obtained by BAL was $90-98 \%$ as verified microscopically (Porter et al., 2002). Cell viability measured by LDH release, trypan blue exclusion and total protein (TPRO) was $89 \pm 5 \%$ (see methods below).

TII Isolation and Purification by Panning: TII isolation was performed according to Jones et al. (1982). Rats were anesthetized intraperitoneally with sodium pentobarbital ( $65 \mathrm{mg} / \mathrm{kg}$ body weight). The abdomen was cut vertically, the intestines pushed aside, and the renal artery cut to exsanguinate the animals. The diaphragm was carefully pierced to deflate the lungs, and the chest cavity was cut open along the midrib line. The heart and lungs were removed en bloc after cutting the trachea above the lungs and the esophagus below the lungs. The lungs were perfused by instilling approximately $20 \mathrm{ml}$ of calcium and magnesium-free PBS through the right ventricle (thin-walled) into the pulmonary artery. Perfusion was completed by instilling approximately $10 \mathrm{ml}$ of the PBS solution through the left ventricle (thick-walled) into each of the pulmonary veins until the lungs were white. Next, an 18 gauge needle coated with plastic tubing (inside diameter $=0.040$ ") was inserted in the trachea. The canula was tied with surgical thread to prevent any movement of the needle during the procedure. While the lungs are being 
massaged, a solution of ice-cold EGTA $(0.2 \mathrm{mM})$ in PBS was repetitively introduced and sucked back out of the lungs through a $10 \mathrm{ml}$ syringe attached to the canula. The first lavage consisted of only $2 \mathrm{ml} / 100 \mathrm{~g}$ body weight to allow any trapped air in the lungs to escape and prevent overinflation of the lungs. Subsequent lavage volumes were $8 \mathrm{mls}$ each, and the total volume of BAL fluid collected during this procedure was approximately $50 \mathrm{ml}$. This fluid, which consisted mainly of AM's, was then discarded. The lungs were subsequently twice lavaged with $8 \mathrm{ml}$ of a digestion solution consisting of $40 \mathrm{U} / \mathrm{ml}$ type I porcine elastase, twice crystallized (ICN Biomedicals Inc., Aurora, $\mathrm{OH}$ ) and $0.018 \%$ DNase from bovine pancreas (USB Corporation, Cleveland, $\mathrm{OH}$ ) in PBS. The rinsed lung was then filled with digestion solution and left to digest for a total of 30 minutes in a $37^{\circ} \mathrm{C}$ water bath. Following digestion, the trachea and the main bronchi were dissected away and discarded. The lungs were chopped with a tissue chopper set at a cut thickness of $0.5 \mathrm{~mm}$. Digestion was then stopped by suspending the minced lung tissue in an elastase inhibitor solution (25\% FBS and 0. 018\% DNase in PBS), and the resultant suspension was successively filtered through 3 nylon mesh sheets of smaller pore sizes $\left(150,330\right.$, and $440 \mathrm{mesh} / \mathrm{cm}^{2}$, New York Stencil, New York, NY). The filtrate was centrifuged at $1000 \mathrm{~g}$ for 10 minutes. The pellet containing unpurified TII cells was then resuspended in $1 \mathrm{ml}$ PBS. The cells were then counted and added to the panning plate for TII purification. The panning plate was prepared according to Dobbs et al. (1986) whereby a $100 \mathrm{~mm}$ tissue culture dish was coated with approximately $2 \mathrm{mg}$ of rat IgG ( Sigma, St Louis, MO) in $4 \mathrm{ml}$ TRIS-base (50mM, pH 9. 5) for 3 hours at room temperature. After this coating period the IgG-treated plate was washed 5 times with $10 \mathrm{ml} \mathrm{PBS}$, and 1 time with $10 \mathrm{ml}$ culture medium (HAM's F-12 
medium supplemented with $1 \mathrm{mM}$ glutamine, $100 \mathrm{U} / \mathrm{ml}$ of penicillin-streptomycin, and $10 \% \mathrm{FBS})$.

The cells were added at a concentration of 20-30 million cells/10 ml culture medium/ IgG-coated culture dish, and incubated for 1 hour at $37^{\circ} \mathrm{C}$, after which the plate was gently rocked and the supernatant which contained the purified TII cells (unlike phagocytes, TII cells are a lung cell type that does not have Fc receptors for IgG and thus would not adhere to the IgG coated plate) was collected and centrifuged. The pellet obtained from the centrifugation was resuspended in $1 \mathrm{ml}$ culture medium, and the cells were counted using an electronic cell counter (Coulter Multisizer II, Coulter Electronics, Hialeah, FL) equipped with a 256 channel cell sizer that counts cells according to their size. TII cells were identified as having a diameter of $7-12 \mu \mathrm{m}$ (Jones et al., 1982), the yield was $25 \pm 8$ million cells/rat (Figure2: Coulter tracing) and the viability was $89.6 \pm$ 2. 4\%. TII cells were incubated overnight before using them in any exposure in order to let them recover from the isolation procedure.

\section{TII Identification and Purity Measurements:}

Fluorescent microscopy:TII cells were identified by fluorescent microscopy upon phosphine 3R (Roboz Surgical Instrument, Washington, DC) staining whereby the lipophylic dye concentrates in the lamellar bodies which store the surfactant to give a yellow-green fluorescence (Mason and Williams, 1976). Phosphine 3R solution in PBS was added to the TII cell suspension at a final concentration of $0.002 \%$. Two minutes later, the stained cells were viewed under a fluorescent microscope (Olympus AX70 photomicroscope equipped with a Sony 3CCD color video camera DXC 9000) at an 
absorption peak of $477 \mathrm{~nm}$ and an emission peak of $512 \mathrm{~nm}$ (Jones et al., 1982).

Phosphine 3R staining of the isolated TII cell preparation is shown in figure 3.

Transmission electron microscopy:TEM was also used to identify TII and estimate their purity. In TEM, the cells were pelleted and fixed overnight in Karnovsky's fixative (2. $5 \%$ gluteraldehyde and 3\% paraformaldehyde in $0.1 \mathrm{M}$ sodium cacodylic buffer $\mathrm{pH} 7$. 4). The pellet was post-fixed in $1 \%$ osmium tetroxide for 60 minutes, rinsed and placed in $1 \%$ tannic acid $(\mathrm{pH} 7.0)$ for 60 minutes, and rinsed and placed in $0.5 \%$ uranyl acetate for 45 minutes, all in a $8 \%$ sucrose and $0.9 \%$ sodium chloride solution. The sample was then dehydrated in an ethanol series and embedded in epon (LX,112, Ladd). The blocks were thin sectioned on a Leica Ultracut and stained with $4 \%$ uranyl acetate for 15 minutes and Reynolds lead citrate for 20 minutes. The sections were viewed on a JOEL 1220 TEM at $80 \mathrm{kev}$. TII cells were identified as having lamellar bodies with swirls of surfactant inside. TII cell purity was $91 \pm 5 \%$ (Fig 4,5$)$.

Rat lung epithelial-T-antigen negative, or RLE-6TN cells were derived from alveolar TII cells by Kevin Driscoll et al. (1995a). Like primary TII cells, RLE-6TN cells contain lamellar bodies for surfactant storage, and they have the ability to produce cytokines, NO and other ROS when stimulated (Stringer and Kobzik, 1998 and Driscoll et al., 2001). Unlike primary TII cells, RLE-6TN cells maintain their morphology and the ability to produce surfactant even after a long time in culture (few days). RLE-6TN cells were obtained commercially (American type culture collection, Manassas, VA).

\section{Cell Viability Measurements:}


Cell viability and number were monitored during cell culture to assure that cell treatments did not cause excessive cellular toxicity or decrease the number of cells surviving in culture.

Lactate dehydrogenase (LDH) activity: LDH was used as an indicator of cell cytotoxicity as this enzyme which is usually in the cell cytoplasm can leak into the medium upon membrane injury and disruption. To measure LDH activity, the exposure plates were spun at $1000 \mathrm{~g}$ for 10 minutes after which the supernatant was collected and part of it was used for LDH measurement. A Cobas Mira Plus analyzer (Roche Diagnostics Systems, Branchburg, NJ) was used to measure LDH release based on the increase in absorbance at $340 \mathrm{~nm}$ during the oxidation of lactate to pyruvate, a reaction catalyzed by LDH. Viability was determined as LDH released into the supernatant under control and test conditions compared to LDH released by the same concentration of lysed cells. Total cellular protein (TPRO): TPRO was used as an indicator of number of cells attached to the culture plate. To measure TPRO, cells were sonicated using a Branson Sonifier 450 (VWR Scientific, Columbus, $\mathrm{OH}$ ) for 30 seconds at a duty cycle of $30 \%$ and an output control of 3, and then centrifuged for 10 minutes at $1000 \mathrm{~g}$. TPRO was measured from the supernatant using a Cobas Mira Plus analyzer (Roche Diagnostics Systems, Branchburg, NJ) based on a colorimetric reaction (absorbance maximum at 540 $\mathrm{nm})$.

Trypan blue exclusion: Trypan blue (Sigma, St Louis, MO) dye exclusion technique was used as an indicator of cell cytotoxicity (Miles et al., 1988); since the dye can only enter the cell when membrane integrity is lost. Trypan blue solution was added to the cell culture wells at a final concentration of $0.04 \%$. After 4 minutes on ice, the cells were 
fixed with $10 \%$ formalin and observed under a light microscope. The percentage of cells excluding dye was taken as the percent viability.

$\mathrm{O}_{2}$ consumption: Mitochondrial function measured by $\mathrm{O}_{2}$ consumption was also an indicator of cell viability and cellular function. To measure oxygen consumption, a Gilson 5/6 oxygraph (Gilson Medical electronics, Middleton, WI), equilibrated with a Clark electrode was used. A baseline was established before adding $3 \times 10^{6}$ cells in $1.5 \mathrm{ml}$ of calcium and magnesium supplemented (1 $\mathrm{mM}$ each) $\mathrm{PBS}$ into a preheated $37^{\circ} \mathrm{C}$ chamber equipped with a stirrer. $\mathrm{O}_{2}$ consumed by the cells was measured over 10 minutes using a standard curve constructed by equilibrating the Clark electrode with solutions bubbled with gases of various $\mathrm{O}_{2}$ concentrations.

Cell Culture: Cell culture medium used for all cell types was HAM's F-12 medium (Biowhittaker, Walkersville, MD) supplemented with $1 \mathrm{mM}$ glutamine, $100 \mathrm{U} / \mathrm{ml}$ of penicillin-streptomycin, and 10\% FBS. For RLE-6TN, the culture medium was supplemented with pituitary extract (bovine, $10 \mu \mathrm{g} / \mathrm{ml}$ ) (Sigma, St Louis, MO), insulin (bovine, $5 \mu \mathrm{g} / \mathrm{ml}$ ) (Sigma, St Louis, MO), IGF-1(human, recombinant,2. $5 \mathrm{ng} / \mathrm{ml}$ ) (Boehringer Mannheim, Indiannapolis, IN) and holo-transferrin (bovine, $25 \mu \mathrm{g} / \mathrm{ml}$ ) (Sigma, St Louis, MO).

All exposures were done in vitro using 12-well culture plates (Fisher, Pittsburgh, PA). Silica exposures used Min-U-Sil 5 ( $99 \%$ of silica particles $<5 \mu \mathrm{m}$ in diameter; purity $=98$. 5\% crystalline silica) obtained from U. S. Silica Corporation (Berkeley Springs, WV), at concentrations $0-100 \mu \mathrm{g} / \mathrm{ml}$ for 18 hour exposures, and $0-600 \mu \mathrm{g} / \mathrm{ml}$ for 30 minute exposures. LPS (Sigma, St Louis, MI) exposures were at concentrations of $0-10 \mu \mathrm{g} / \mathrm{ml}$ for AM's and TII cells' 18 hour exposures, and 0-100 $\mu \mathrm{g} / \mathrm{ml}$ for RLE-6TN cells' 18 hour 
exposures. LPS exposure concentrations for the three cell types for all 30 minute exposures were $0-600 \mu \mathrm{g} / \mathrm{ml}$. When added to the culture, the TNF- $\alpha$ (Biosource, Camarillo,CA), IL-1 $\beta$ (Biosource, Camarillo,CA), prostaglandin E2 (PGE2) and leukotriene B4 (LTB4) (Sigma, St Louis, MO) final concentration used was 50ng/ml, and $\mathrm{H}_{2} \mathrm{O}_{2}$ (Sigma, St Louis, MO) was added at a final concentration of $50 \mu \mathrm{M}$. The tissue culture plates were centrifuged following exposures at $1000 \mathrm{~g}$ for 10 minutes before collecting the medium. While some of the post-exposure medium was used right away for $\mathrm{LDH}$ and TPRO measurement, the rest of it was stored in a $-70^{\circ} \mathrm{C}$ freezer for future TNF- $\alpha$, MIP-2, IL-1 $\beta$, IL-6 and NO measurement. As for the cells attached to the bottom of the wells, they were used to measure cellular viability. In all experiments, exposure time for NO , TNF- $\alpha$, MIP-2, IL-1 $\beta$ and IL-6 studies was 18 hours. Exposure time for ROS and $\mathrm{O}_{2}{ }^{-}$studies was 30 minutes. All exposures were performed in a $37{ }^{\circ} \mathrm{C}$ $10 \% \mathrm{CO}_{2}$ incubator.

\section{Co-culture Systems:}

Mixed co-culture: In a 12-well plate, TII and AM cells were cultured in the same well at a concentration of $0.25 \times 10^{6}$ cell $/ \mathrm{ml}$ for each cell type. Silica exposures used Min-U-Sil 5 (silica particles $<5 \mu \mathrm{m}$ ) obtained from U. S. Silica Corporation (Berkeley Springs, WV), at a final concentration of $100 \mu \mathrm{g} / \mathrm{ml}$ for 18 hour exposures. LPS (Sigma, St Louis, MI) exposures were at a final concentration of $10 \mu \mathrm{g} / \mathrm{ml}$. When fibrinogen (Sigma, St Louis, MO) was used to inhibit surfactant, it was initially dissolved in warm saline and then added to the co-culture at a final concentration of $0.8 \mathrm{mg} / \mathrm{ml}$. All exposures were performed in a $37{ }^{\circ} \mathrm{C} 10 \% \mathrm{CO}_{2}$ incubator. Figure 6 shows a micrograph of the cells in the mixed co-culture plate showing close contact. 
Transwell co-culture: In a 12-well plate, AM and TII cells were separated by $0.4 \mu \mathrm{m}$ pore size inserts (Fisher, Pittsburgh, PA) which are placed in the main wells. While TII cells were on the bottom of the plate submerged in a total volume of $1500 \mu \mathrm{l}$ (medium plus or minus stimulant plus or minus inhibitor). AM's were lying on the insert surface submerged in a total volume of $500 \mu \mathrm{l}$ (medium plus or minus stimulant plus or minus inhibitor). Figure 7 is a diagram of a 12 -well plate transwell with dimensions. Either one of the compartments can be exposed to the stimulant or just PBS. Cell concentration used for both cell types was $0.25 \times 10^{6}$ cells $/ \mathrm{ml}$. Exposure time for LDH, NO , and cytokines measurement was 18 hours. Fluid from both compartments was pooled after exposure to measure cell mediators. Inhibitors were dissolved in PBS prior to their addition into the co-culture medium with different final concentrations used for different inhibitors. N-acetyl cysteine (NAC) (Sigma, St Louis, MO) was used as a non-specific antioxidant at $1 \mathrm{mM}$; vitamin $\mathrm{C}($ Sigma, St Louis, MO) was used as another non-specific antioxidant at $250 \mu \mathrm{M}$; superoxide dismutase (SOD) (Sigma, St Louis, MO) was used as a superoxide inhibitor at $250 \mathrm{U} / \mathrm{ml}$; catalase (Sigma, St Louis, MO) was used as a hydrogen peroxide inhibitor at $5000 \mathrm{U} / \mathrm{ml}$; nordihydroguaiaretic acid (NDGA) (Sigma St Louis, MO) was used as a lipooxygenase inhibitor at $1 \mu \mathrm{M}$; indomethacin (Sigma St Louis, MO) was used as a cyclooxygenase inhibitor at $1 \mu \mathrm{M}$; anti-TNF- $\alpha$ (R\&D systems, Minneapolis, MN) was used as a TNF- $\alpha$ neutralizing antibody at $0.5 \mu \mathrm{g} / \mathrm{ml}$; and anti-IL$1 \beta(\mathrm{R} \& \mathrm{D}$, Minneapolis, MN) was used as an IL-1 $\beta$ neutralizing antibody at $0.2 \mu \mathrm{g} / \mathrm{ml}$. Exposure time for NO , TNF- $\alpha$, MIP-2, IL-1 $\beta$ and IL-6 measurement was 18 hours. All exposures were performed in a $37^{\circ} \mathrm{C} 10 \% \mathrm{CO}_{2}$ incubator.

\section{Conditioned medium cell culture:}


In a 12-well plate, AM and TII cells were cultured separately and without any exposure at a concentration of $0.25 \times 10^{6}$ cells $/ \mathrm{ml}$. TII-conditioned culture medium and AMconditioned culture medium were respectively transferred to AM's and TII cells 18 hours later.

\section{Superoxide Anion $\left(\mathrm{O}_{2}^{-}\right)$Measurement by Cytochrome C Reduction:}

Measurment of $\mathrm{O}_{2}^{-}$release using cytochrome $\mathrm{C}$ spectrophotometry relies on the change in absorbance of cytochrome $\mathrm{C}(550 \mathrm{~nm})$ following its reduction by $\mathrm{O}^{-\cdot}$ (Miles et al., 1978). Cytochrome C (Sigma, St Louis, MO) dissolved in Hepes-buffered medium (10mM Hepes, $145 \mathrm{mM} \mathrm{NaCl}, 5 \mathrm{mM} \mathrm{KCl}, 1 \mathrm{mM} \mathrm{CaCl}_{2}$ and $5.5 \mathrm{mM}$ D-glucose; $\mathrm{pH}=7$. 4) was added to all wells at a final concentration of $0.12 \mathrm{mM}$. $2 \times 10^{6}$ cells / $\mathrm{ml}$ in $96-$ well microplates were exposed to $0-600 \mu \mathrm{g} / \mathrm{ml}$ LPS or $0-600 \mu \mathrm{g} / \mathrm{ml}$ silica for 30 minutes at $37^{\circ} \mathrm{C}$. Cytochrome $\mathrm{C}$ reduction was measured before and after exposure using a SpectraMax 250 spectrophotometer. Conversion from $\Delta \mathrm{OD}$ units to $\mathrm{O}_{2}^{-}$. concentration was performed using the following formula: $\mathrm{CL}=\Delta \mathrm{OD} / \mathrm{e}$ where $\mathrm{C}$ is the $\mathrm{O}_{2}{ }^{\circ}$ concentration expressed in $\mathrm{mM}, \mathrm{L}$ is the path length in $\mathrm{cm}, \Delta \mathrm{OD}$ is the change in cytochrome $\mathrm{C}$ absorbance and e is the $\mathrm{O}_{2}^{-\cdot}$ extinction coefficient of $18.7 \mathrm{mM}^{-1} \mathrm{~cm}^{-1}$.

\section{ROS Measurement:}

Luminol-dependent chemiluminescence(CL): Measurment of ROS using luminol (5amino-2,3-dihydro-1,4-phthalazinedion)-amplified chemiluminescence relies on the oxidation of luminol by $\mathrm{H}_{2} \mathrm{O}_{2}$ /peroxidase system to form a luminol radical that produces chemiluminescence (Li et al., 1999). A 22mM luminol stock solution was made by dissolving $4 \mathrm{mg}$ luminol (Sigma, St Louis, MO) in $100 \mu \mathrm{l}$ DMSO and then adding $900 \mu \mathrm{l}$ of Hepes-buffered medium to the DMSO-dissolved luminol. The 96-well plate with a 
cell concentration of $2 \times 10^{6}$ cells $/ \mathrm{ml}$ in Hepes-buffered medium (10mM Hepes, $145 \mathrm{mM}$ $\mathrm{NaCl}, 5 \mathrm{mM} \mathrm{KCl}, 1 \mathrm{mM} \mathrm{CaCl}_{2}$ and $5.5 \mathrm{mM}$ D-glucose; $\mathrm{pH}=7.4$ ) was placed in the $37^{\circ} \mathrm{C}$ preheated measurement chamber where $1 \mathrm{mM}$ luminol (final concentration) was added to each well at time 0 . PBS, LPS $(0-600 \mu \mathrm{g} / \mathrm{ml})$ or silica $(0-600 \mu \mathrm{g} / \mathrm{ml})$ were then injected into specified wells, and ROS measured for 30 minutes with emission at $460 \mathrm{~nm}$ on the LB96P microplate luminometer. Chemiluminescence (CL) was expressed as relative light units (RLU) per $2 \times 10^{6}$ cells per 30 minutes.

Confocal microscopy: Two different fluorescent dyes were used to microscopically detect ROS; Dichlorodihydrofluorescein (DCFH), or dihydroethydium. To prepare the stained cell slides, $0.1-1 \times 10^{6}$ cells were placed in $24-$ well plates with coverslips (pretreated with serum) inside the wells. Two hours later, the wells with cells inside were gently washed with warm $\left(37^{\circ} \mathrm{C}\right)$ glucose solution $(5 \mathrm{mM}$ glucose in PBS), and either DCFH (dissolved in $5 \mathrm{mM}$ glucose solution and added at a final concentration of $25 \mu \mathrm{M}$ ) or dihydroethydium (dissolved in 5mM glucose solution and added at a final concentration of $10 \mu \mathrm{M})$ dye was added in the dark. The cells were then exposed to PBS, LPS (0$600 \mu \mathrm{g} / \mathrm{ml})$ or silica $(0-600 \mu \mathrm{g} / \mathrm{ml})$ for 30 minutes in a $37{ }^{\circ} \mathrm{C} 10 \% \mathrm{CO}_{2}$ incubator, and subsequently gently washed with the same glucose solution used earlier. The cells were then fixed with $10 \%$ phosphate-buffered formalin solution for 10 minutes, after which the wells were gently washed once with PBS and the coverslips placed on glass slides and left to dry overnight. To view the stained cells, an LSM 510 Axiovert 200M confocal microscope (Carl Zeiss, Inc., Thornwood, NY) was used; DCFH dye gave off green fluorescence at $488 \mathrm{~nm}$ when it reacted with released ROS, whereas dihydroethydium gave off red fluorescence at $543 \mathrm{~nm}$ upon its reaction with ROS. 
NO Measurement: Frozen post-exposure supernatants were thawed and used for NO measurement. Since NO is a very unstable gas, the only way to chemically measure its release is by measuring its oxidation products, nitrate $\left(\mathrm{NO}_{3}\right)$ and nitrite $\left(\mathrm{NO}_{2}\right)$, collectively referred to as total $\mathrm{NO}$. A total $\mathrm{NO}$ assay kit obtained from Assay Designs, Inc (Ann Arbor, MI) was used to measure NO in 96-well microplates. The kit included a nitrate reductase to convert $\mathrm{NO}_{3}$ to $\mathrm{NO}_{2}$. It also included Greiss reagents that interact with $\mathrm{NO}_{2}$ in a colorimetric reaction the products of which absorb light at $540 \mathrm{~nm}$. A series of $\mathrm{NO}_{2}$ standards were run in parallel with the samples, and this standard curve was used to convert light absorbance units into NO concentrations. A SpectraMax 250 spectrophotometer was used to read the microplate absorbances and convert them to total NO concentrations.

Cytokine Measurement: Frozen post-exposure supernatants were thawed and used for cytokine measurements. TNF- $\alpha$, MIP-2, IL-1 $\beta$ and IL- 6 cytokine concentrations were measured using cytokine-specific ELISA (enzyme-linked immunosorbent assay) kits obtained from Biosource International (Camarillo, CA). The kits included 96-well microtiter plates with cytokine-specific antibody coated wells. The assay involved a sandwich ELISA where cytokines in the samples attach to their specific antibody in the well and are detected colorimetrically upon binding to another added antibody. A series of cytokine standards were run in parallel with the samples, and this standard curve was used to convert light absorbances into cytokine concentrations. A SpectraMax 250 spectrophotometer was used to read the microplate absorbances and convert them to cytokine concentrations.

\section{Diffusion Through the Transwell:}


To measure how well mediators and surfactant can cross the transwell insert, TNF$\alpha(5 \mathrm{ng} / \mathrm{ml})$ (Sigma, St Louis,MO) and artificial surfactant, Survanta (2mg/ml) (Abbott Laboratories, Columbus, $\mathrm{OH}$ ) were added to the bottom of the well, and they were measured 18 hours later both from the bottom of the well and from the insert.

\section{Surfactant Phospholipids Measured by Phosphorus Content:}

Tissue culture medium phospholipid was measured according to Porter et al. (2001).

Briefly, $0.5 \mathrm{ml}$ fluid sample was mixed with $10 \mathrm{ml} \mathrm{CHCl}_{3}: \mathrm{MeOH}(2: 1, \mathrm{v} / \mathrm{v})$ followed by incubation for 1.5 hours at room temperature to extract the lipid. A $2 \mathrm{ml}$ aliquot of icecold $0.1 \mathrm{M} \mathrm{KCl}$ was then added, and the samples were mixed by inversion and then centrifuged for 5 minutes at $2500 \mathrm{rpm}$. The top layer was then aspirated away and the bottom layer washed 3 times by addition and aspiration of $\mathrm{CHCl}_{3}: \mathrm{MeOH}: \mathrm{H}_{2} \mathrm{O}(3: 48: 47$, $\mathrm{v} / \mathrm{v} / \mathrm{v})$, then dried. . The samples were then heated overnight at $150-160^{\circ} \mathrm{C}$ after addition of $0.5 \mathrm{ml}$ of water and $0.5 \mathrm{ml}$ of $10 \mathrm{~N} \mathrm{H}_{2} \mathrm{SO}_{4}$. A $100 \mu$ aliquot of $30 \% \mathrm{H}_{2} \mathrm{O}_{2}$ were then added to the samples before they were heated for another 1.5 hours. Inorganic phosphate was determined colorimetrically at $830 \mathrm{~nm}$ using a UV-2401 spectrophotometer (Shimadzu; Columbia, MD), and a series of phosphate standards were run in parallel to the samples.

Statistics: All data are means \pm SEM of at least 3 trials. A Student " $t$ " test was used for mean comparison. $\mathrm{p}<0.05$ was considered statistically significant. 
Figure 1: Coulter tracing for AM's ( diameter 9-18 $\mu \mathrm{m}$ ). AM's were isolated by BAL of rat lungs. Particles smaller than $9 \mu \mathrm{m}$ on this graph are mostly debris.

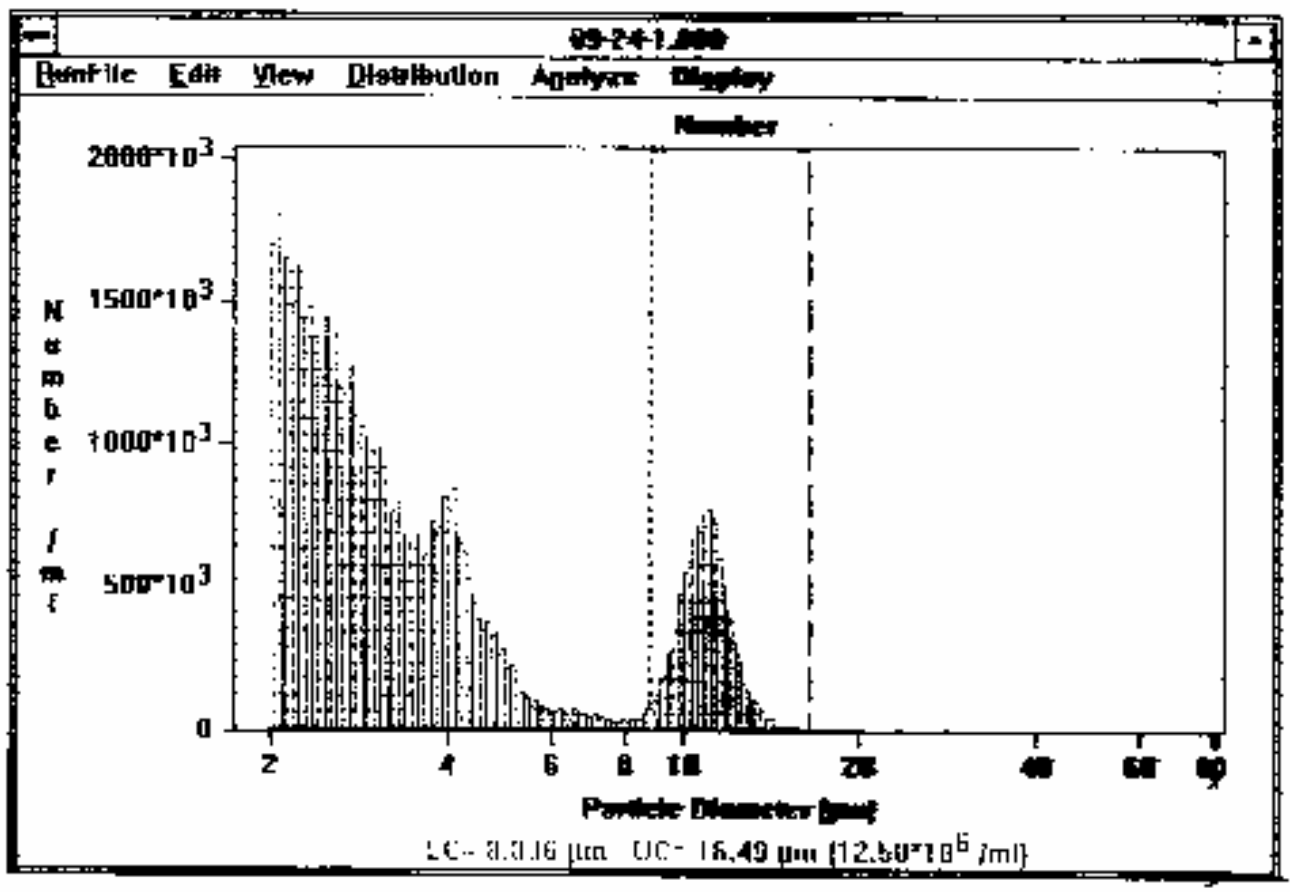


Figure 2: Coulter tracing for TII cells (7-12 $\mu \mathrm{m}$ in diameter) isolated by elastase digestion of the lung and purified by differential adherence to IgG-coated surface. TII, being a lung cell type not possessing $\mathrm{Fc}$ receptors for $\mathrm{IgG}$, are purified in the supernatant after adherence of the other cells. a- Before adherence; b- After adherence

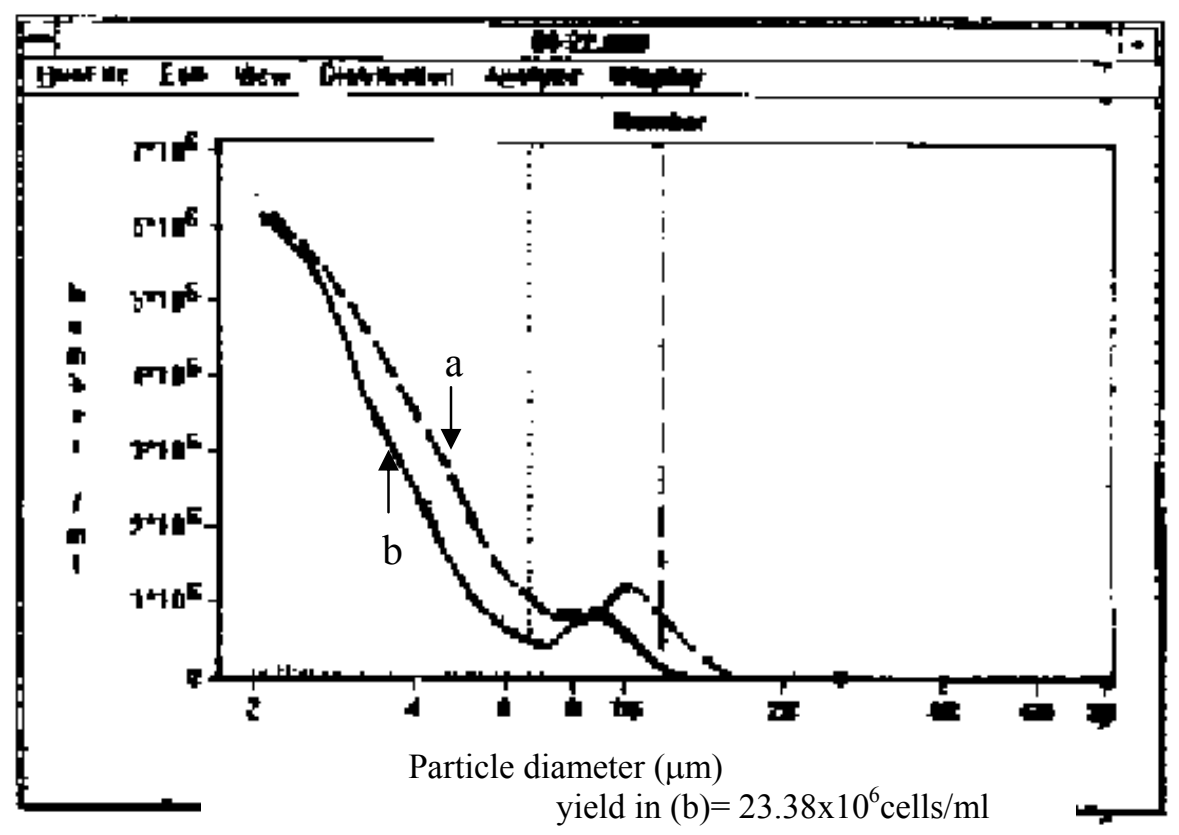


Figure 3A: Fluorescent microscopy of TII cells stained with phosphine 3R. The globular inclusions emitting fluorescence are the lamellar bodies which contain surfactant and concentrate the lipophylic dye. 3B: Focusing on a single TII cell staining positively with phosphine 3R

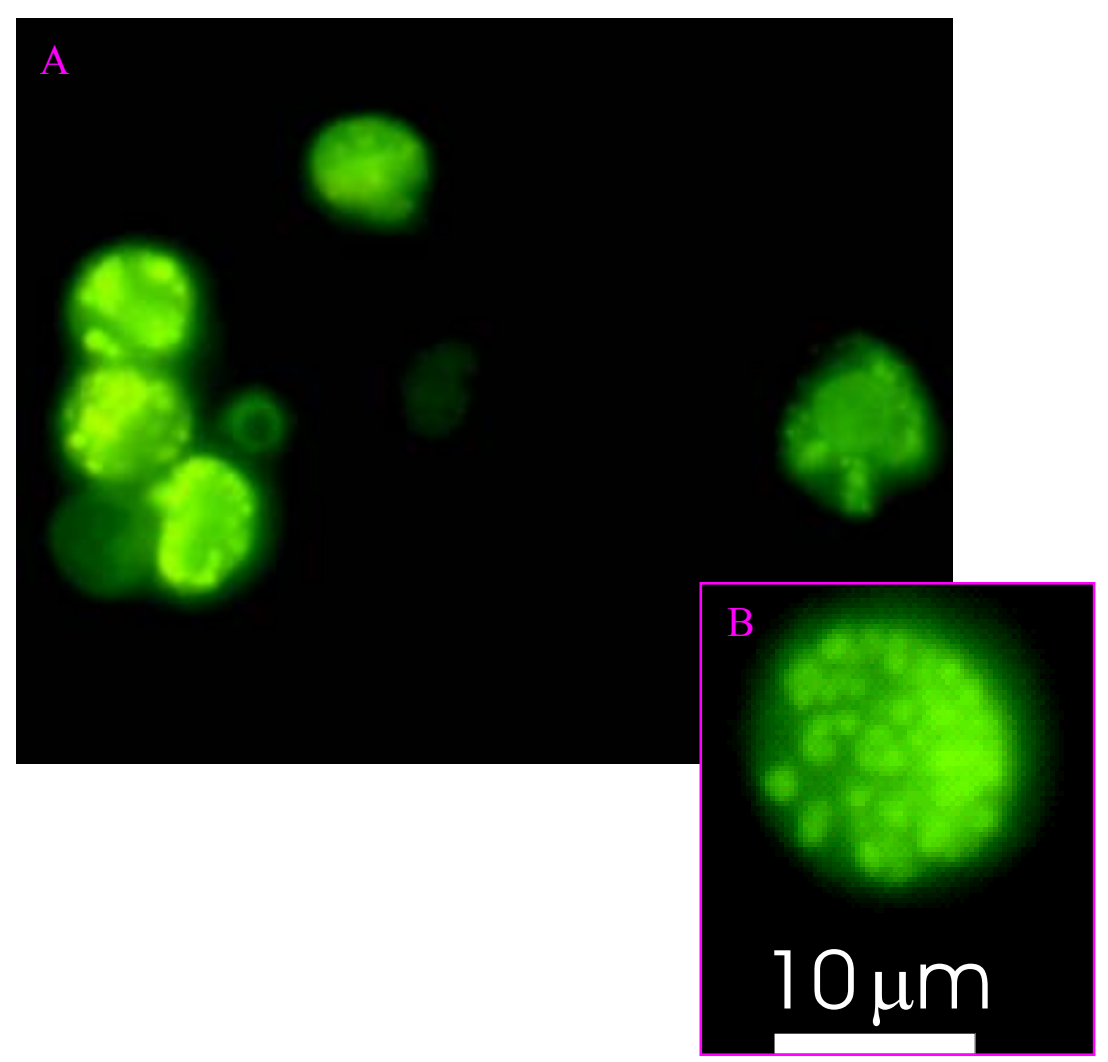


Figure 4: TEM of a TII cell $(\mathrm{x} 22,000)$. The stained swirls consist of phospholipids surfactant in the lamellar bodies.

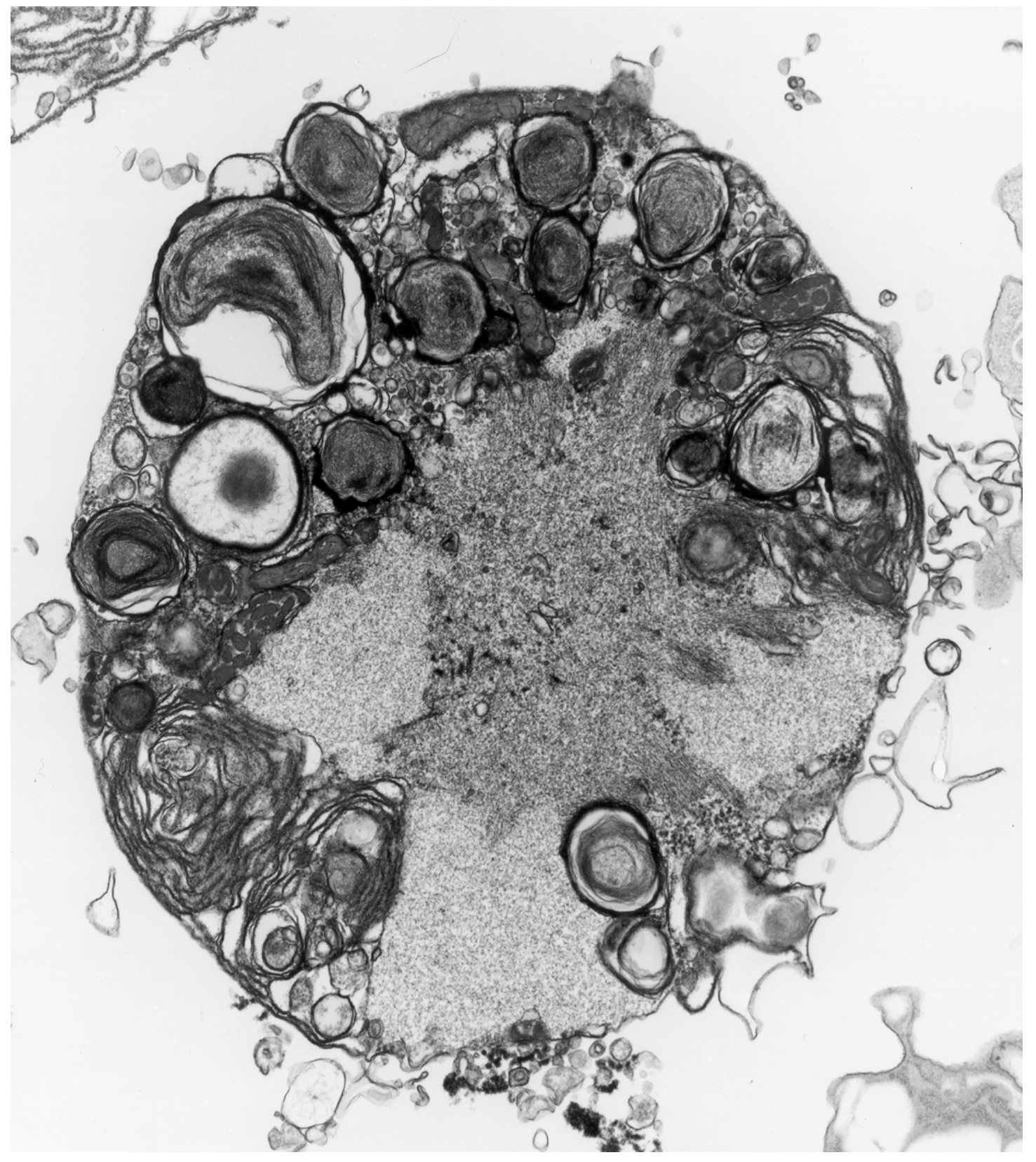


Figure 5: TEM of a cell sample following TII isolation and purification by adherance. TII cells are identified by swirls of surfactant inside them. Marked cells are TII.

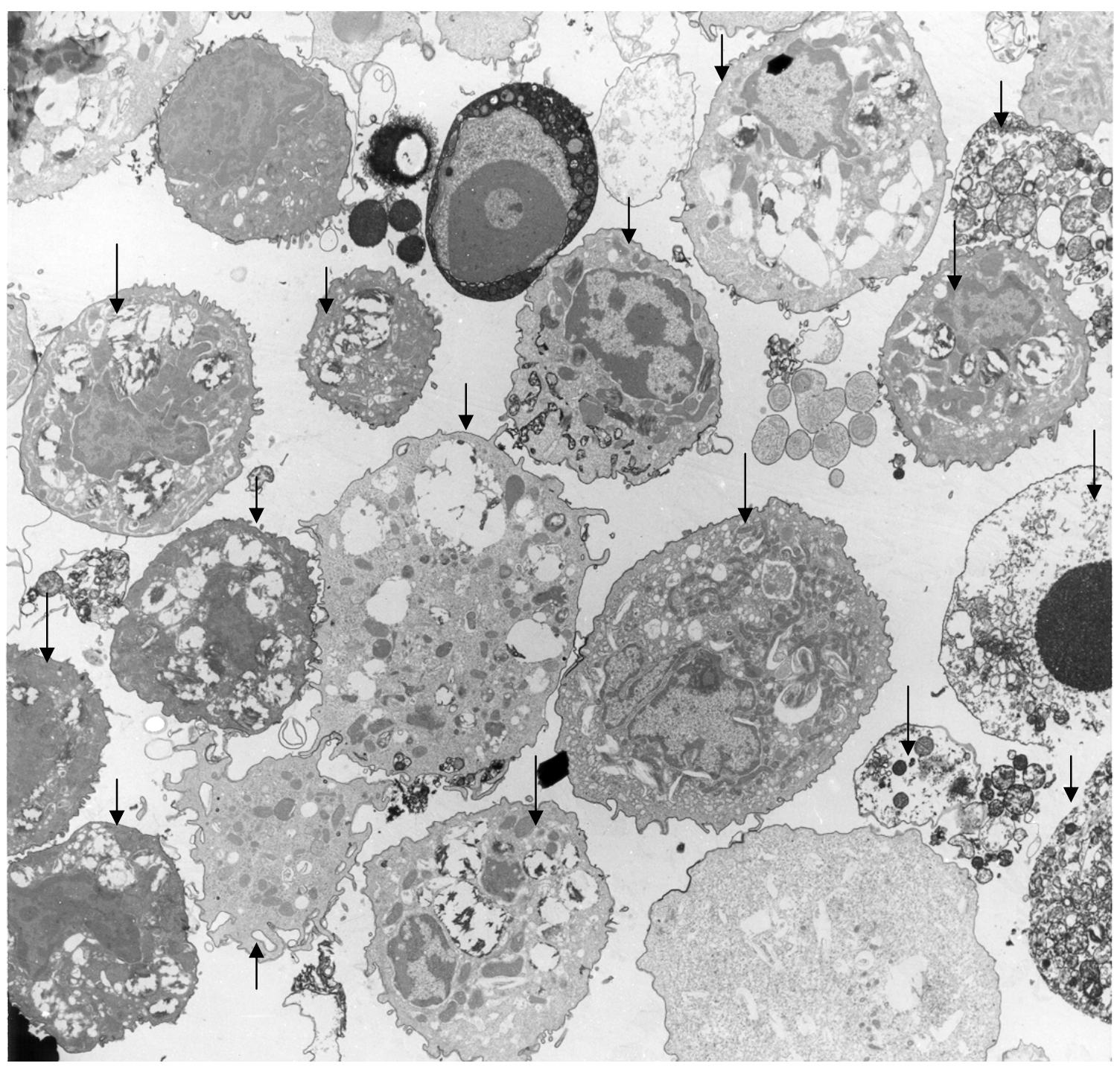


Figure 6: Micrograph of AM and TII cells in mixed co-culture. $0.5 \times 10^{6}$ AM's and 0. $5 \times 10^{6} \mathrm{TII}$ cells are co-cultured together in a 12-well tissue culture plate in a total volume of $2 \mathrm{ml}$. Note how the cells are in close contact.

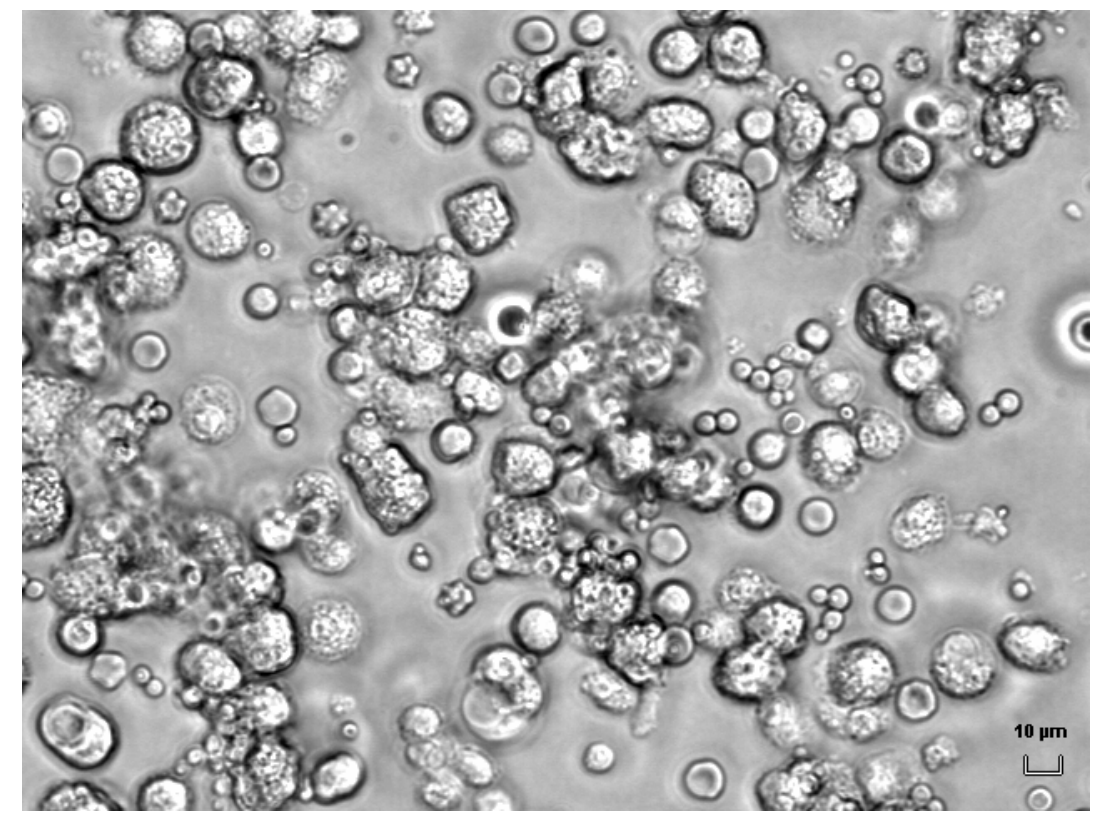


Figure 7: A 12-well plate transwell with dimensions. AM's $\left(0.25 \times 10^{6}\right.$ cells $\left./ \mathrm{ml}\right)$ were placed in the insert, while $0.5 \times 10^{6} \mathrm{TII}$ cells were in the bottom of the well. The media from both compartments were in contact. The transwell insert has a pore size of $0.4 \mu \mathrm{m}$.

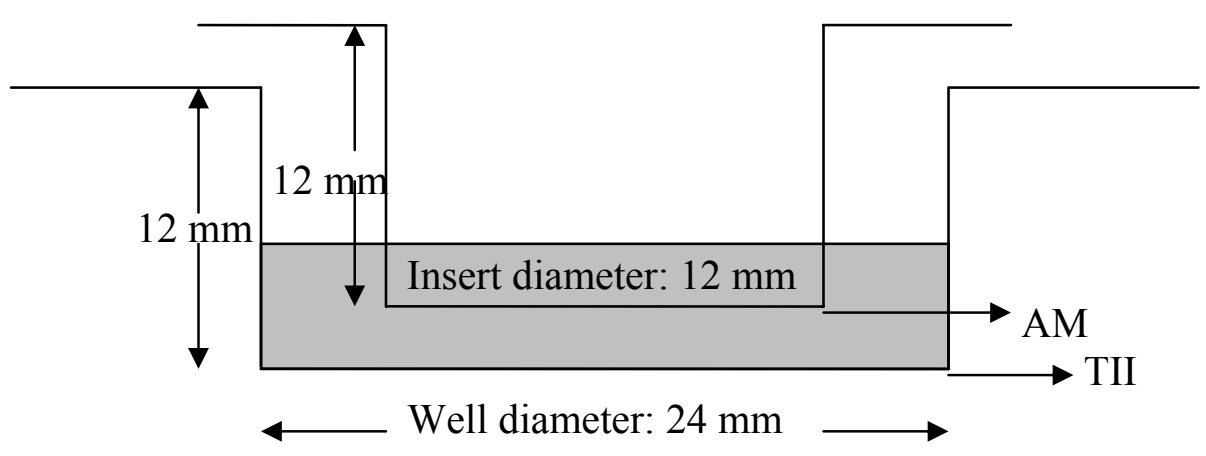




\section{$\underline{\text { Results }}$}

Objective: To advance the understanding of the role of AM and TII in the induction of pulmonary inflammation and injury in response to silica and LPS.

Aim 1: Determine the relative responsiveness of AM, primary TII and a TII cell line to silica and LPS under comparable conditions by comparing the mediator release by primary rat AM's, primary rat TII, and a rat TII cell line (RLE-6TN) upon stimulation with LPS or silica.

$\underline{\text { Results for aim 1: }}$

Cell cytotoxicity following LPS and silica exposures: Cell cytotoxicity was measured to check for any cell death that might have been caused by LPS or silica exposure, and the number of cells was measured to check if the cell concentration remained constant throughout the 18 hour exposure period.

LPS did not cause substantial cytotoxicity or cell disintegration at the doses used in these cultures over the 18-hour exposure period in AM's (Table 1 and Figure 8), TII cells (Table 2 and Figure 9), or RLE-6TN cells (Table 3 and Figure 10). Also, silica did not cause substantial cytotoxicity or cell disintegration below $50 \mu \mathrm{g} / \mathrm{ml}$ in AM's (Table 4 and Figure 11), TII cells (Table 5 and Figure 12), or RLE-6TN cells (Table 6 and Figure 13). However, some cytotoxicity was noted at the $100 \mu \mathrm{g} / \mathrm{ml}$ silica exposure for some assays. NO release upon LPS and silica exposure: LPS dose-responsively increased NO production from the three cell types (Figure 14). Primary AM's produced considerably more NO in response to LPS than primary TII cells, which in turn were more active than RLE-6TN cells in response to LPS exposure. Silica exposure in vitro did not result in any detectable NO production from the 3 cell types. In contrast, silica is a potent 
inducer of NO production from BAL cells after in vivo exposure, and a potent inducer of iNOS in AM's and TII cells (Porter et al., 2002 b). Huffman and colleagues have shown that silica induction of iNOS in AM's requires communication between different types of alveolar cells (Huffman et al., 1998). Such cross-talk is absent in this in vitro study. TNF- $\alpha$ release upon LPS and silica exposure: Both LPS and silica dose-responsively increased TNF- $\alpha$ production from primary AM's and primary TII cells, but not from RLE-6TN cells (Figures 15 and 16). Also, primary AM's were more responsive to both LPS and silica in TNF- $\alpha$ release than primary TII cells, which in turn were more active than RLE-6TN cells. LPS induced far greater production of TNF- $\alpha$ from AM's and primary TII cells than silica did.

MIP-2 release upon LPS and silica exposure: Both LPS and silica dose-responsively increased MIP-2 production from primary AM's, primary TII and RLE-6TN cells (Figures 17 and 18). Primary AM's were more active in inducing MIP-2 release than primary TII cells, which in turn were more active than RLE-6TN cells. LPS induced far greater production of MIP-2 from the 3 cell types than silica did.

IL-1 $\beta$ release upon LPS and silica exposure: LPS and silica dose-responsively increased IL-1 $\beta$ production from primary AM's and primary TII cells, but not from RLE-6TN cells (Figures 19 and 20). Primary AM's were more active in inducing IL-1 $\beta$ release than primary TII cells, which in turn were more active than RLE-6TN cells. Unlike the production of NO , TNF- $\alpha$ and MIP-2 where LPS was more potent than silica, both agents induced comparable production of IL- $1 \beta$ from the 3 cell types.

IL-6 release upon LPS and silica exposure: LPS and silica dose-responsively increased IL-6 production from primary AM's, primary TII and RLE-6TN cells (Figures 21 and 22). 
Upon LPS exposure, the 3 cell types had somewhat comparable abilities to produce IL-6, although RLE-6TN cells were not responsive to low $(<0.1 \mu \mathrm{g} / \mathrm{ml})$ concentrations of LPS. Upon silica exposure, primary AM's were less active in inducing IL-6 release than primary TII cells, which in turn were less active than RLE-6TN cells. LPS induced a greater production of IL- 6 from the 3 cell types than silica did.

$\mathrm{O}_{2}^{-}$release with LPS and silica exposure: Silica dose-responsively increased $\mathrm{O}_{2}{ }^{-}$ production from primary AM's, primary TII and RLE-6TN cells (figures 23, 24 and 25). Upon silica exposure, primary AM's and TII cells had comparable ability to produce $\mathrm{O}_{2}{ }_{2}^{-}$, and that was greater than RLE-6TN ability. Silica induced a greater production of $\mathrm{O}_{2}^{-}$ from the 3 cell types than did LPS, since no $\mathrm{O}_{2}{ }^{-}$release from the 3 cell types was noted with LPS exposure.

ROS release with LPS and silica exposure: LPS dose-responsively increased ROS production from primary AM's measured externally as CL and internally with ROSsensitive dyes (figures 26 and 27). However, LPS failed to stimulate ROS from primary TII or RLE-6TN cells. Silica dose-responsively increased ROS production from primary AM's (figures 28 and 29) and TII cells (figures 30 and 31), but not from RLE-6TN. Upon silica exposure, AM's and TII cells had comparable abilities to produce ROS. Silica induced a greater production of ROS from AM's and TII cells than LPS did since LPS didn't induce any detectable ROS in TII.

Aim 2: Determine if intercellular interactions exist and under what conditions they can be demonstrated by evaluating the effect of rat AM mediator release on the physiological functions of primary rat alveolar TII cells and visa versa under basal conditions, or upon LPS or silica exposure. For this step, 2 types of co-culture systems were developed, a 
transwell co-culture system and a mixed co-culture system. Also, to evaluate the role of surfactant in AM/TII interaction, fibrinogen, a surfactant inhibitor (Seeger et al., 1993;

Gupta et al., 2000), was added in some mixed co-culture experiments.

\section{$\underline{\text { Results for aim 2: }}$}

TNF- $\alpha$ release in the co-culture systems: Figure 32 shows that in the transwell co-culture system, there was considerable potentiation of TNF- $\alpha$ release compared to the sum of mediator release from the 2 cell types cultured separately under basal conditions. Similar potentiation was also observed upon silica exposure. Upon LPS stimulation, transwell co-culture of the 2 cell types resulted in simply an additive (no interaction) TNF- $\alpha$ release. In the mixed co-culture system, the potentiation seen under basal conditions and upon silica exposure was removed, and there was an inhibition upon LPS stimulation of the mixed co-culture system compared to the sum of TNF- $\alpha$ productions by AM and TII cells cultured separately. Miles et al. (1999) have reported that surfactant can inhibit LPS-induced NO production by AM's. We have shown that in the mixed co-culture system AM's and TII cells are in close contact (Figure 6). Therefore, we speculated that TII cells could release surfactant which would down regulate cytokine production by AM's. This inhibiton might not be seen in the transwell system where AM's and TII cells are separated by a considerable distance. To test this hypothesis, the effects of fibrinogen, a surfactant inhibitor, were monitored for AM plus TII in mixed culture under basal conditions. Upon adding fibrinogen, the potentiation of TNF- $\alpha$ release in the mixed co-culture system was significantly increased, i. e., the inhibitory effect of close cell contact was removed (Figure 33). 
MIP-2 release in the co-culture systems: As Figure 34 shows, in the transwell co-culture system, MIP-2 release was considerably potentiated compared to the sum of mediator release from the 2 cell types cultured separately under basal conditions and upon silica exposure. Upon LPS stimulation, the 2 cell types did not alter each others' MIP-2 release, i. e., the MIP-2 release was additive. In the mixed co-culture system, the potentiation seen under basal conditions and upon silica exposure was removed, and there was an inhibition upon LPS stimulation of the mixed co-culture system compared to the sum of MIP-2 release from AM's and TII cells cultured separately. Upon adding fibrinogen, the inhibition of MIP-2 release in the mixed co-culture system under unstimulated conditions was significantly reversed, i. e., potentiation of basal MIP-2 release was observed in the mixed co-culture upon treatment with fibrinogen (Figure 35). $\mathrm{NO}$ release in the co-culture systems: In the transwell co-culture system, NO production was considerably potentiated compared to the sum of mediator release from the 2 cell types cultured separately under basal conditions. Upon LPS or silica stimulation, the 2 cell types did not alter each others' NO release, i. e., additive NO production was seen. In the mixed co-culture system, the potentiation seen in the transwell system under basal conditions was reversed into an inhibiton, and there was an inhibition upon LPS and silica stimulation of the mixed co-culture system below the additive production (Figure 36). Upon adding fibrinogen, the inhibition of NO release by the mixed co-culture system under unstimulated conditions was significantly attenuated (Figure 37). IL-1 $\beta$ release in the co-culture systems: In the transwell co-culture system: no significant potentiation of IL- $1 \beta$ release was noted compared to the sum of mediator release from the 
2 cell types cultured separately under basal conditions or upon LPS stimulation. Upon silica exposure, considerable potentiation of IL-1 $\beta$ release was seen. In the mixed coculture system, there was no change in the basal IL- $1 \beta$ release compared to the transwell co-culture system. However, the potentiation seen upon silica exposure was removed, and there was an inhibition upon LPS stimulation of the mixed co-culture system (Figure $38)$.

Upon adding fibrinogen to the mixed co-culture system under basal conditions, there was a significant increase in IL-1 $\beta$ release compared to the mixed cells with no fibrinogen under unstimulated conditions; i. e., potentiation became evident (Figure 39). IL-6 release in the co-culture system: In the transwell co-culture system, considerable potentiation of IL-6 release was noted compared to the sum of mediator release from the 2 cell types cultured separately under basal conditions and upon LPS and silica stimulation. In the mixed co-culture system, there was no change in the IL-6 release compared to the transwell co-culture system under unstimulated conditions, but the potentiation seen upon LPS or silica exposure was removed (Figure 40). Upon adding fibrinogen to the mixed culture system, there was no change in IL-6 release compared to the mixed cells with no fibrinogen under basal conditions (Figure 41).

Filter effect on AM's: The question arised as to whether the filter of the transwell insert itself could have a stimulatory effect on AM's. TNF- $\alpha$ and MIP-2 were measured from 0. $25 \times 10^{6}$ AM's grown for 18 hours either on a plate or in the transwell insert. Figure 42 shows that in fact the filter has a slight inhibitory effect on AM's. Therefore, the potentiation of mediator release observed under transwell co-culture conditions cannot be accounted for by the filter effect. 
Mediators and surfactant diffusion through the transwell filter: TNF- $\alpha(5 \mathrm{ng} / \mathrm{ml})$ or Survanta $(2 \mathrm{mg} / \mathrm{ml})$ were placed in the bottom compartment of the transwell and they were measured 18 hours later in both the bottom compartment and the insert to check if they diffused freely through the insert or if they were blocked partially or totally by the filter. Figure 43A shows that TNF- $\alpha$ levels were not significantly different in the separate compartments, and thus TNF- $\alpha$ can freely diffuse through the transwell filter. As for Survanta, according to Figure $43 \mathrm{~B}$, only about $20 \%$ diffused from the plate bottom into the insert through the transwell, which means that the transwell filter significantly inhibits surfactant diffusion between the two compartements. Fibrinogen as a surfactant inhibitor: Unlike the situation for AM's, surfactant does not inhibit LPS-stimulated mediator production by RAW cells (Rao et al., FASEB J. 1999). Therefore, RAW cells were mixed co-cultured with TII cells in the presence or absence of fibrinogen, and TNF- $\alpha$ and MIP-2 were measured in both cases (Figure 44). No change in the TII/RAW co-culture response was observed with or without fibrinogen, which suggests that the increase in AM/TII mixed co-culture potentiation upon adding fibrinogen was not a nonspecific fibrinogen effect.

Aim 3: Attempt to identify the mediator(s) responsible for the AM/TII intercellular interaction by trying to identify which mediator(s) contribute significantly to the interaction of AM's and TII cells in a transwell system under basal conditions. For this step, different mediator inhibitors were added to unstimulated transwell co-culture plates. $\mathrm{N}$-acetyl cysteine (NAC) (Sigma, St Louis, MO) was used as a non-specific antioxidant at $1 \mathrm{mM}$; vitamin C (Sigma, St Louis, MO) was used as another non-specific antioxidant at $250 \mu \mathrm{M}$; superoxide dismutase (SOD) (Sigma, St Louis, MO) was used as a 
superoxide inhibitor at $250 \mathrm{U} / \mathrm{ml}$; catalase (Sigma, St Louis, MO) was used as a hydrogen peroxide inhibitor at $5000 \mathrm{U} / \mathrm{ml}$; nordihydroguaiaretic acid (NDGA) (Sigma St Louis, MO) was used as a lipooxygenase inhibitor at $1 \mu \mathrm{M}$; indomethacin (Sigma St Louis, MO) was used as a cyclooxygenase inhibitor at $1 \mu \mathrm{M}$; anti-TNF- $\alpha$ (R\&D systems, Minneapolis, MN) was used as a TNF- $\alpha$ neutralizing antibody at $0.5 \mu \mathrm{g} / \mathrm{ml}$; and anti-IL$1 \beta(\mathrm{R} \& \mathrm{D}$, Minneapolis, MN) was used as an IL-1 $\beta$ neutralizing antibody at $0.2 \mu \mathrm{g} / \mathrm{ml}$. $\underline{\text { Results for Aim 3: }}$

Results from addition of inhibitors: No cytotoxicity was noted upon addition of any inhibitor in the study. However, all inhibitors used significantly decreased TNF- $\alpha$ potentiation in AM/TII transwell co-cultures under basal conditions (Figures $45 \mathrm{~A}$ ); also, all inhibitors except anti-IL-1 $\beta$ significantly decreased MIP-2 potentiation (Figures 45 B). These results suggest that oxidants, lipooxygenase and cyclooxygenase products (leukotrienes and prostaglandins), TNF- $\alpha$, and IL-1 $\beta$ could all be involved in AM/TII intercellular communication.

Results from addition of mediators: In addition to adding inhibitors to attempt to identify mediator(s) that contribute to the interaction of AM and TII cells in a transwell system under basal conditions, different mediators and/or their combinations were added to either AM or TII cultures. Mediators added were hydrogen peroxide $\left(\mathrm{H}_{2} \mathrm{O}_{2}\right)(50 \mu \mathrm{M})$ which is an oxidant product, TNF- $\alpha$ protein used at $50 \mathrm{ng} / \mathrm{ml}, \mathrm{IL}-1 \beta$ protein used at 50 $\mathrm{ng} / \mathrm{ml}$, prostaglandin E2 (PGE2) at $50 \mathrm{ng} / \mathrm{ml}$ which is a product of cyclooxygenase, and leukotriene B4 (LTB4) $(50 \mathrm{ng} / \mathrm{ml})$ which is a lipooxygenase product. None of the mediators or their combinations caused cytotoxicity in AM's or TII cells. However, in general addition of mediators to AM or TII cultures did not affect release of 
TNF- $\alpha$ or MIP-2 (Figures 46 A, 47 A and 47 B). The only exception was a significant stimulatory action of TNF- $\alpha$ on MIP-2 production by AM's (Figure $46 \mathrm{~B}$ ). Addition of other mediators in combination to TNF- $\alpha$ to AM's did not augment the stimulatory effect of TNF- $\alpha$ alone (Figure 48).

Conditioned media results: A third way of trying to identify mediators for the AM/TII communication was to expose AM's to TII-conditioned medium or expose TII cells to AM-conditioned medium. AM's cultured in TII-conditioned medium did not release more TNF- $\alpha$ or MIP-2 than control AM's (Figure 49). However, TII cells cultured in an 18-hour AM-conditioned medium released significantly more TNF- $\alpha$ and MIP-2 than control TII cells (Figure 50). These results suggest that some mediator(s) released from AM's basally is/are able to potentiate TII basal response. To check if this/these mediators include TNF- $\alpha$ or IL- $1 \beta$, an anti-TNF- $\alpha$ or anti-IL-1 $\beta$ neutralizing antibody was added to the TII culture when adding the 18-hour AM-conditioned medium to it. Neither the anti-TNF- $\alpha$ nor the anti-IL-1 $\beta$ decreased the potentiation conferred to TII cells by adding the AM-conditioned medium to them (Figures $51 \mathrm{~A}$ and $\mathrm{B}$ ). These results suggest that neither TNF- $\alpha$ nor IL- $1 \beta$ is a main mediator released from AM's basally which potentiates TII cells. 
Table 1: LPS-induced cytotoxicity in primary rat AM's measured by LDH release into the medium and the percentage of cell nuclei stained with trypan blue. $10^{6}$ cells $/ \mathrm{ml}$ were exposed to increasing LPS concentrations for 18 hours. Values are presented as change from control (means $\pm \mathrm{SE}$ of 5 experiments). Note that the total LDH release for $1 \times 10^{6}$ sonicated AM's $\sim 115 \mathrm{U} / \mathrm{L}$.

\begin{tabular}{|c|c|c|}
\hline LPS Dose $(\mu \mathrm{g} / \mathrm{ml})$ & $\begin{array}{c}\text { Exposure-Induced } \\
\text { LDH Release (U/L) }\end{array}$ & $\begin{array}{c}\text { Exposure-Induced } \\
\text { Cell Nuclei with } \\
\text { Trypan Blue (\%) }\end{array}$ \\
\hline 0 & $0 \pm 0$ & $0.0 \pm 0.0$ \\
\hline 0.025 & $6.8 \pm 5.6$ & $1.8 \pm 1.2$ \\
\hline 0.05 & $5.8 \pm 5.8$ & $3.5 \pm 2.2$ \\
\hline 0.1 & $1.6 \pm 1.6$ & $1.3 \pm 1.3$ \\
\hline 1 & $2.4 \pm 2.4$ & $2.8 \pm 2.4$ \\
\hline 5 & $5.2 \pm 3.6$ & $2.0 \pm 1.2$ \\
\hline
\end{tabular}


Figure 8: TPRO from primary rat AM's upon LPS exposure. $10^{6}$ cells $/ \mathrm{ml}$ were exposed to increasing LPS concentrations for 18 hours. Values are means \pm SE of 4 experiments. Note that TPRO is an indicator of cell number.

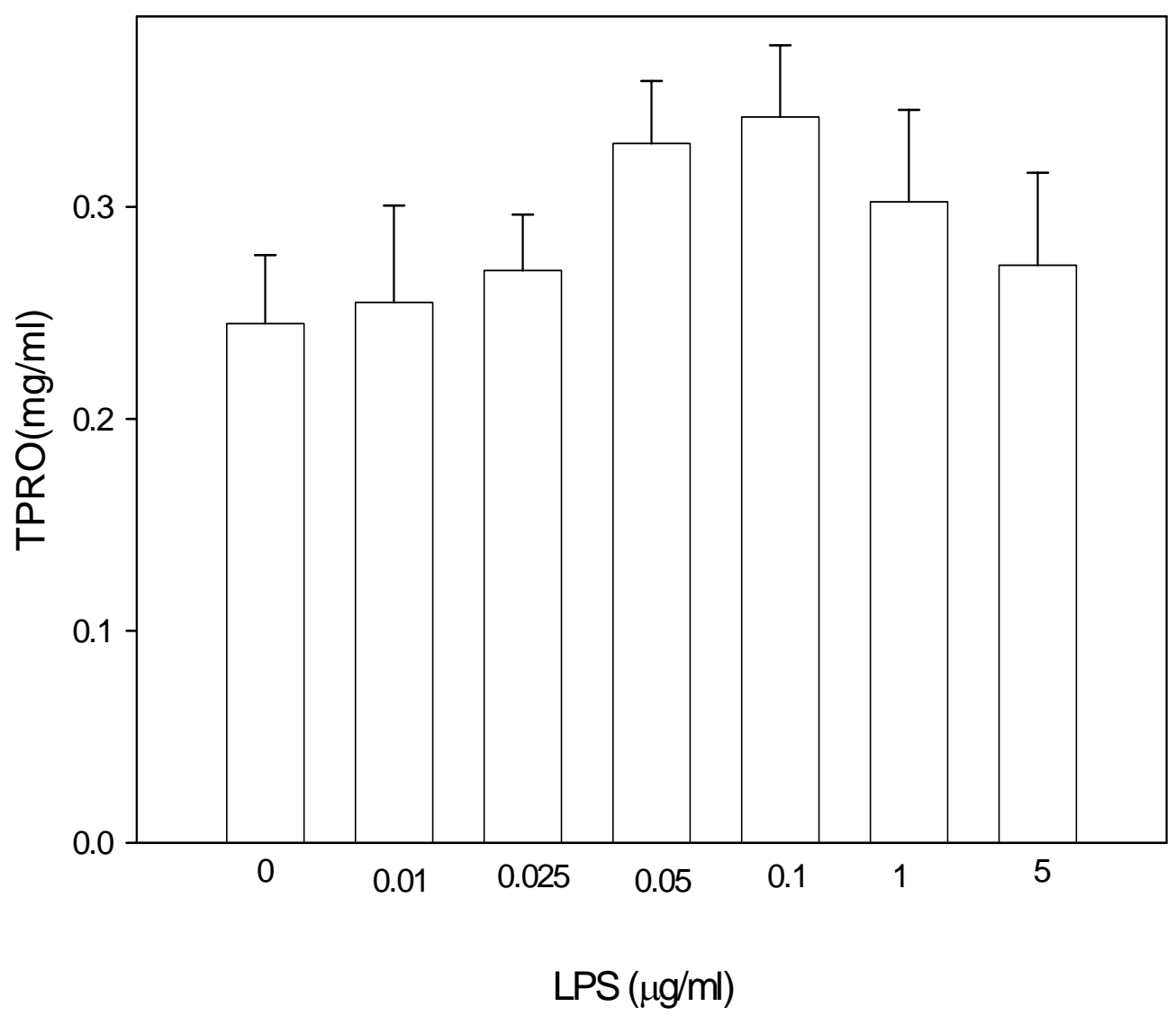


Table 2: LPS-induced cytotoxicity in primary rat TII cells measured by LDH release into the medium and the percentage of cell nuclei stained with trypan blue. $10^{6}$ cells $/ \mathrm{ml}$ were exposed to increasing LPS concentrations for 18 hours. Values are presented as change from control (means $\pm \mathrm{SE}$ of 4 experiments). Note that the total LDH release for $1 \times 10^{6}$ sonicated TII cells $\sim 170 \mathrm{U} / \mathrm{L}$.

\begin{tabular}{|l|l|l|}
\hline LPS Dose $(\mu \mathrm{g} / \mathrm{ml})$ & $\begin{array}{l}\text { Exposure-Induced } \\
\text { LDH Release(U/L) }\end{array}$ & $\begin{array}{l}\text { Exposure-Induced } \\
\text { Cell Nuclei with } \\
\text { Trypan Blue (\%) }\end{array}$ \\
\hline 0 & $0 \pm 0$ & $0.0 \pm 0.0$ \\
\hline 0.025 & $0 \pm 0$ & $0.75 \pm 0.75$ \\
\hline 0.05 & $0 \pm 0$ & $3.25 \pm 1.89$ \\
\hline 0.1 & $0 \pm 0$ & $1.0 \pm 1.0$ \\
\hline 1 & $0.75 \pm 0.75$ & $2.25 \pm 1.65$ \\
\hline 5 & $0.75 \pm 0.48$ & $2.75 \pm 1.89$ \\
\hline
\end{tabular}


Figure 9: TPRO from primary rat TII cells upon LPS exposure. $10^{6}$ cells $/ \mathrm{ml}$ were exposed to increasing LPS concentrations for 18 hours. Values are means \pm SE of 4 experiments. Note that TPRO is an indicator of cell number.

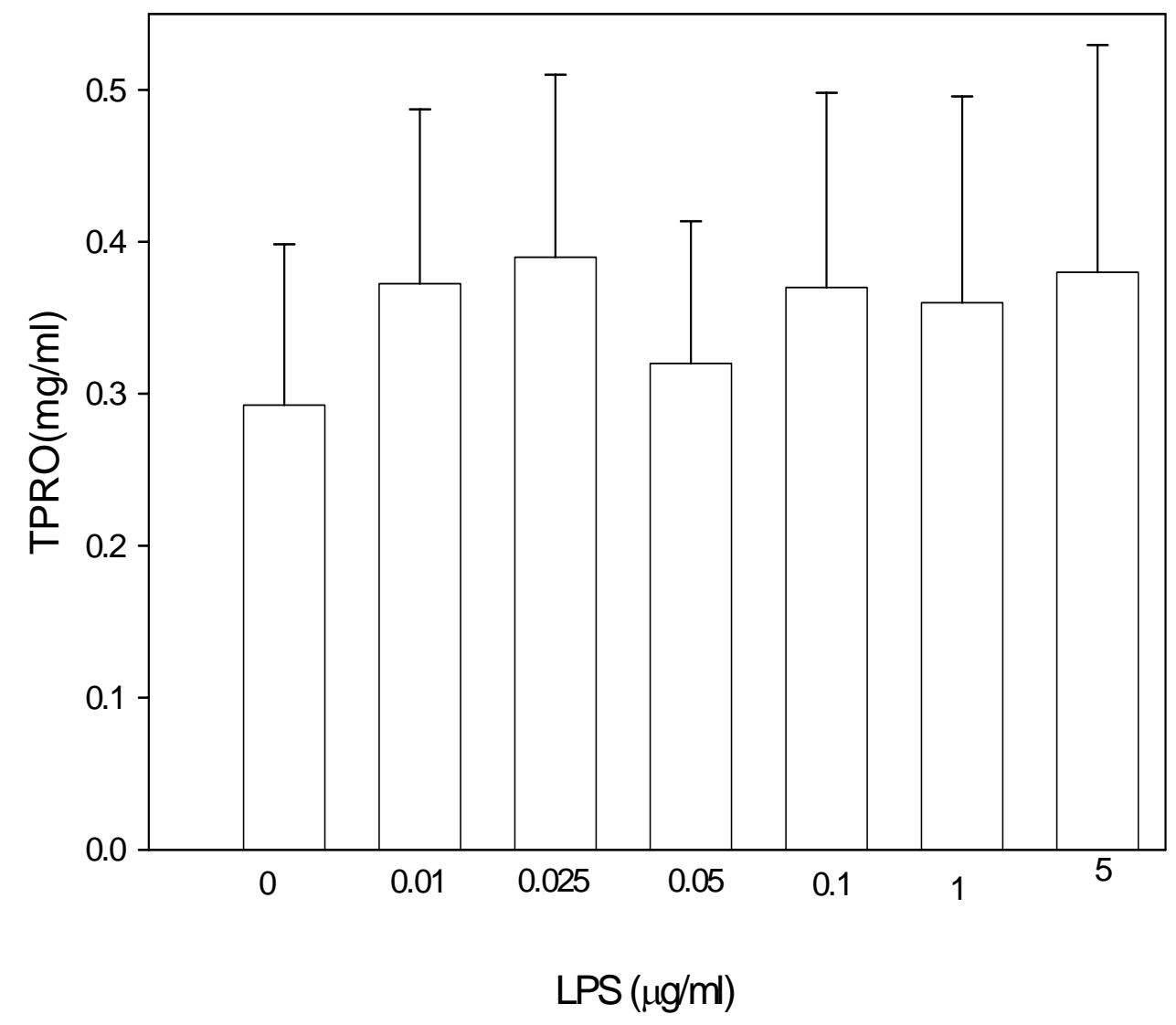


Table 3: LPS-induced cytotoxicity in RLE-6TN cells measured by LDH release into the medium and the percentage of cell nuclei stained with trypan blue. $10^{6}$ cells $/ \mathrm{ml}$ were exposed to increasing LPS concentrations for 18 hours. Values are presented as change from control (means \pm SE of 4 experiments). Note that the total LDH release for $1 \times 10^{6}$ sonicated RLE-6TN $~ 505 \mathrm{U} / \mathrm{L}$.

\begin{tabular}{|l|l|l|}
\hline LPS Dose $(\mu \mathrm{g} / \mathrm{ml})$ & $\begin{array}{l}\text { Exposure-Induced } \\
\text { LDH Release (U/L) }\end{array}$ & $\begin{array}{l}\text { Exposure-Induced } \\
\text { Cell Nuclei with } \\
\text { Trypan Blue (\%) }\end{array}$ \\
\hline 0 & $0 \pm 0$ & $0.0 \pm 0.0$ \\
\hline 10 & $3.5 \pm 2.6$ & $1.4 \pm 1.4$ \\
\hline 25 & $13.8 \pm 3.8$ & $3.6 \pm 2.54$ \\
\hline 50 & $6.5 \pm 4.3$ & $1.0 \pm 1.0$ \\
\hline 75 & $2 \pm 2$ & $0.40 \pm 0.40$ \\
\hline 100 & $3 \pm 3$ & $1.6 \pm 1.6$ \\
\hline
\end{tabular}


Figure 10: TPRO from RLE-6TN cells upon LPS exposure. $10^{6}$ cells $/ \mathrm{ml}$ were exposed to increasing LPS concentrations for 18 hours. Values are means $\pm \mathrm{SE}$ of 4 experiments. Note that TPRO is an indicator of cell number.

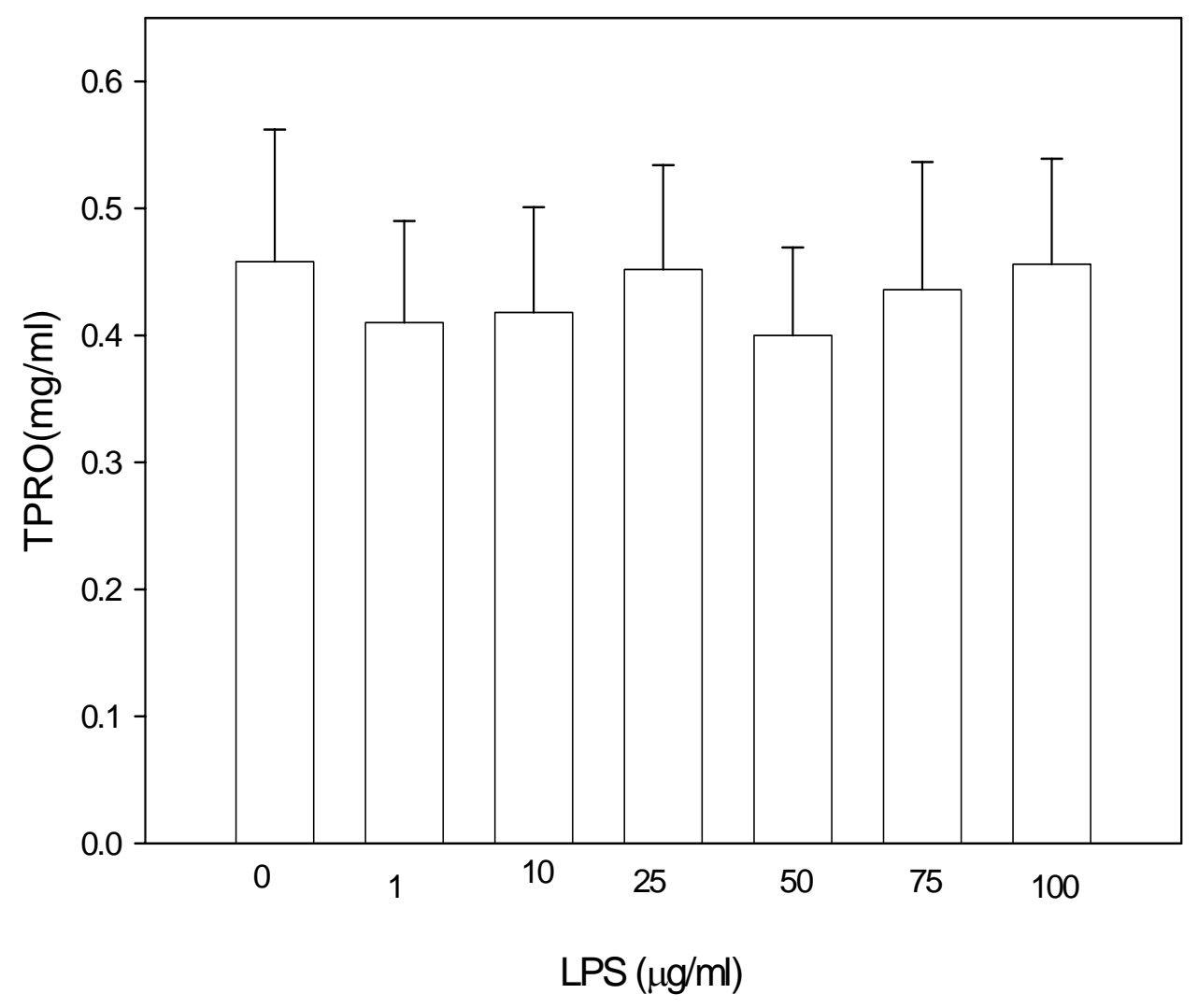


Table 4: Silica-induced cytotoxicity in primary rat AM's measured by LDH release into the medium and the percentage of cell nuclei with trypan blue. $10^{6}$ cells $/ \mathrm{ml}$ were exposed to increasing silica concentrations for 18 hours. Values are presented as change from control (means $\pm \mathrm{SE}$ of 4 experiments). Note that the total LDH release for $1 \times 10^{6}$ sonicated AM's $\sim 115 \mathrm{U} / \mathrm{L}$.

\begin{tabular}{|l|l|l|}
\hline Silica Dose $(\mu \mathrm{g} / \mathrm{ml})$ & $\begin{array}{l}\text { Exposure-Induced } \\
\text { LDH Release (U/L) }\end{array}$ & $\begin{array}{l}\text { Exposure-Induced } \\
\text { Cell Nuclei with } \\
\text { Trypan Blue (\%) } \\
0.0 \pm 0.0\end{array}$ \\
\hline 0 & $0.0 \pm 0.0$ & $0.75 \pm 0.75$ \\
\hline 5 & $16.7 \pm 13.3$ & $3.0 \pm 1.78$ \\
\hline 50 & $11.0 \pm 6.6$ & $5.25 \pm 2.56$ \\
\hline 50 & $27.0 \pm 12$ & $6.5 \pm 2.72$ \\
\hline 100 & $52.0 \pm 4.8$ & \\
\hline
\end{tabular}


Figure 11: TPRO from primary rat AM's upon silica exposure. $10^{6}$ cells $/ \mathrm{ml}$ were exposed to increasing silica concentrations for 18 hours. Values are means \pm SE of 4 experiments. Note that TPRO is an indicator of cell number.

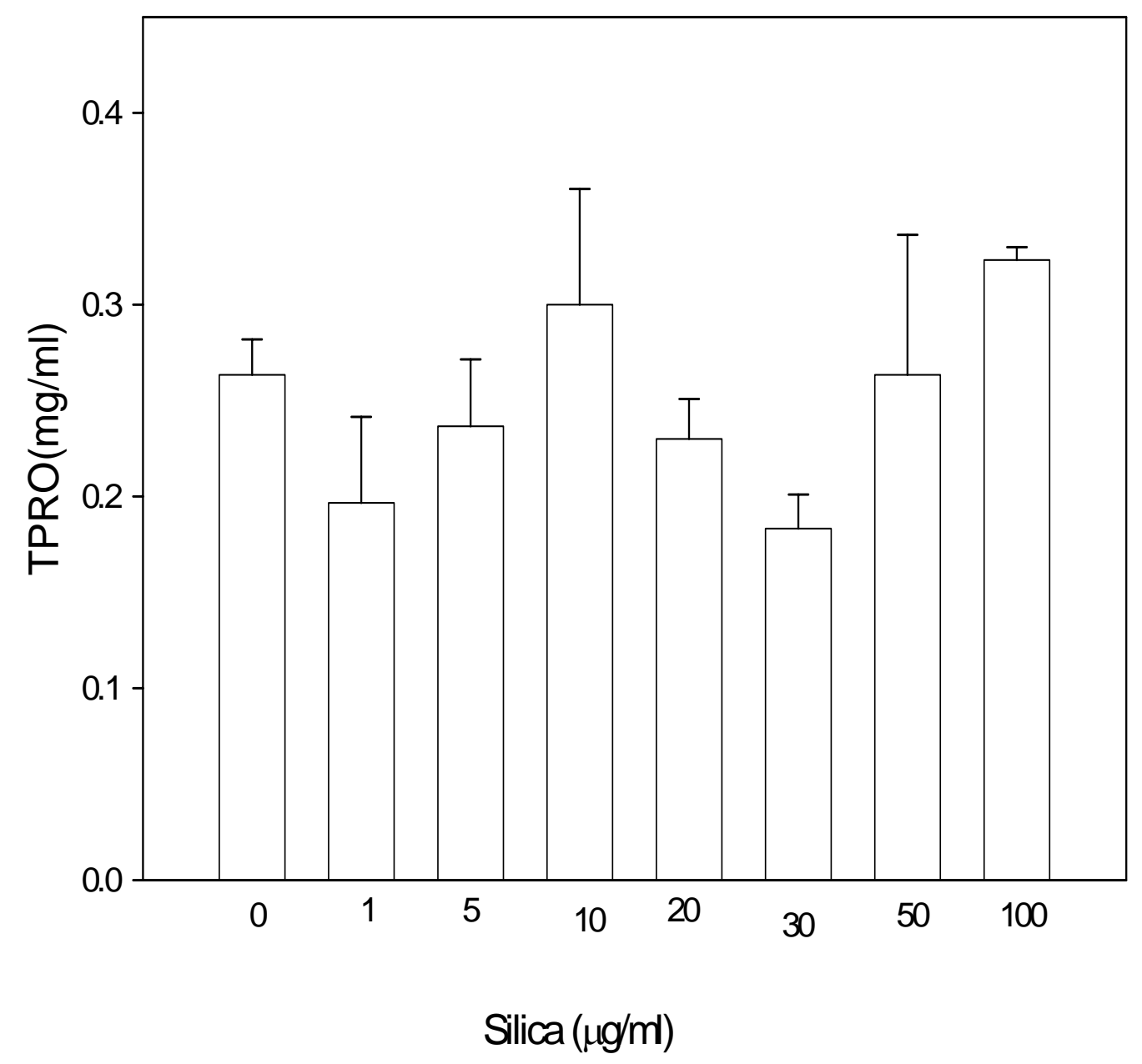


Table 5: Silica-induced cytotoxicity in primary rat TII cells measured by LDH release into the medium and the percentage of cell nuclei stained with trypan blue. $10^{6}$ cells $/ \mathrm{ml}$ were exposed to increasing silica concentrations for 18 hours. Values are presented as change from control (means $\pm \mathrm{SE}$ of 4 experiments). Note that the total LDH release for $1 \times 10^{6}$ sonicated TII cells $\sim 170 \mathrm{U} / \mathrm{L}$.

\begin{tabular}{|l|l|l|}
\hline Silica Dose $(\mu \mathrm{g} / \mathrm{ml})$ & $\begin{array}{l}\text { Exposure-Induced } \\
\text { LDH Release(U/L) }\end{array}$ & $\begin{array}{l}\text { Exposure-Induced } \\
\text { Cell Nuclei with } \\
\text { Trypan Blue (\%) } \\
0.0 \pm 0.0\end{array}$ \\
\hline 0 & $0.0 \pm 0.0$ & $0.75 \pm 0.75$ \\
\hline 5 & $0.0 \pm 0.0$ & $3.0 \pm 1.78$ \\
\hline 25 & $0.25 \pm 0.25$ & $5.25 \pm 2.56$ \\
\hline 50 & $1.0 \pm 0.71$ & $6.5 \pm 2.72$ \\
\hline 100 & $13.5 \pm 5.78$ & \\
\hline
\end{tabular}


Figure 12: TPRO from primary rat TII cells upon silica exposure. $10^{6}$ cells $/ \mathrm{ml}$ were exposed to increasing silica concentrations for 18 hours. Values are means \pm SE of 4 experiments. Note that TPRO is an indicator of cell number.

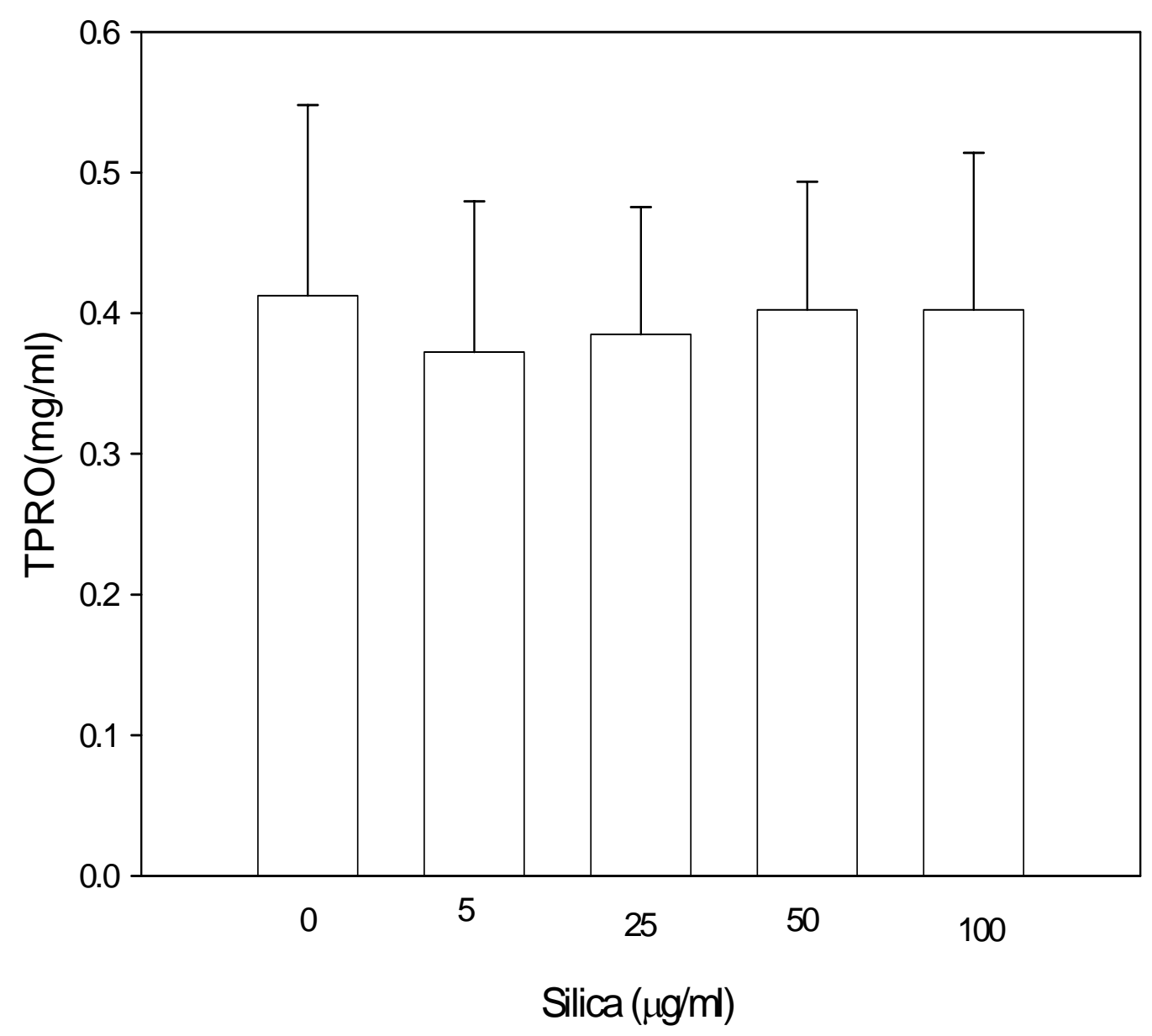


Table 6: Silica-induced cytotoxicity in RLE-6TN cells measured by LDH release into the medium and the percentage of cell nuclei stained with trypan blue. $10^{6}$ cells $/ \mathrm{ml}$ were exposed to increasing silica concentrations for 18 hours. Values are presented as change from control (means \pm SE of 4 experiments). Note that the total LDH release for $1 \times 10^{6}$ sonicated RLE-6TN $\sim 505 \mathrm{U} / \mathrm{L}$.

\begin{tabular}{|l|l|l|}
\hline Silica Dose $(\mu \mathrm{g} / \mathrm{ml})$ & $\begin{array}{l}\text { Exposure-Induced } \\
\text { LDH Release(U/L) }\end{array}$ & $\begin{array}{l}\text { Exposure-Induced } \\
\text { Cell Nuclei with } \\
\text { Trypan Blue (\%) }\end{array}$ \\
\hline 0 & $0.0 \pm 0.0$ & $0.0 \pm 0.0$ \\
\hline 5 & $13.0 \pm 13.0$ & $3.4 \pm 1.5$ \\
\hline 20 & $24.5 \pm 24.5$ & $2.8 \pm 1.8$ \\
\hline 50 & $46.8 \pm 46.8$ & $3.8 \pm 2.0$ \\
\hline 100 & $84.3 \pm 28.6$ & $7.4 \pm 1.6$ \\
\hline
\end{tabular}


Figure 13: TPRO from RLE-6TN cells upon silica exposure. $10^{6}$ cells/ml were exposed to increasing silica concentrations for 18 hours. Values are means $\pm \mathrm{SE}$ of 4 experiments. Note that TPRO is an indicator of cell number.

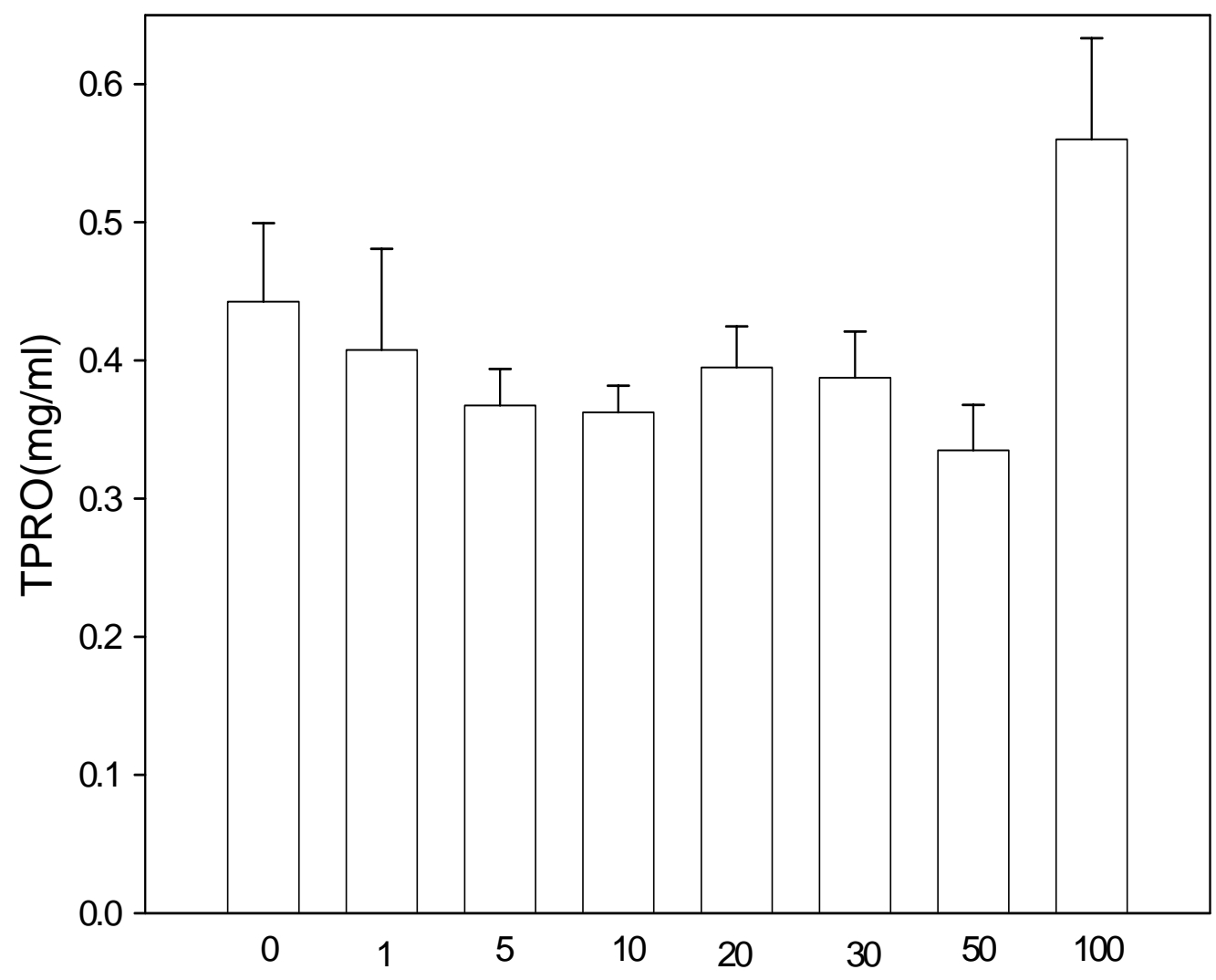

Silica $(\mu \mathrm{g} / \mathrm{ml})$ 
Figure 14: Exposure- induced NO release from the 3 cell types upon LPS exposure. $1 \times 10^{6}$ cells $/ \mathrm{ml}$ were exposed to increasing concentrations of LPS for 18 hours. Values are means $\pm \mathrm{SE}$ of 4 experiments. Note the break in the $\mathrm{x}$-axis. * indicates a significant difference $(p<0.05)$ from control (0 LPS) for each cell type.

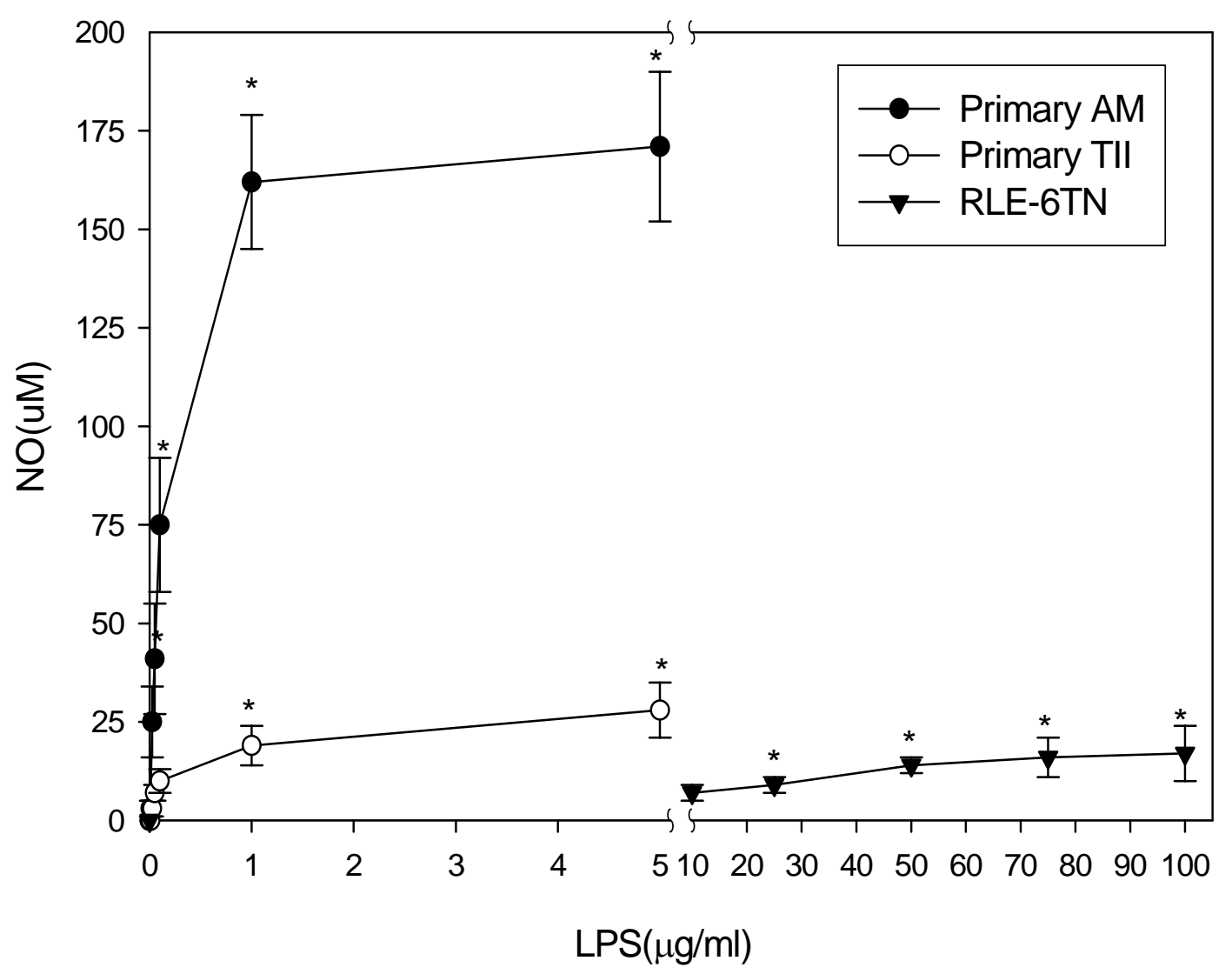


Figure 15: Exposure- induced TNF- $\alpha$ release from the 3 rat alveolar cell types upon LPS exposure. $1 \times 10^{6}$ cells $/ \mathrm{ml}$ were exposed to increasing concentrations of LPS for 18 hours. There was no detectable TNF- $\alpha$ release from RLE-6TN cells upon LPS exposure. Values are means $\pm \mathrm{SE}$ of 4 experiments. Note the breaks in the axes. * indicates a significant difference $(p<0.05)$ from control (0 LPS) for AM's and TII cells.

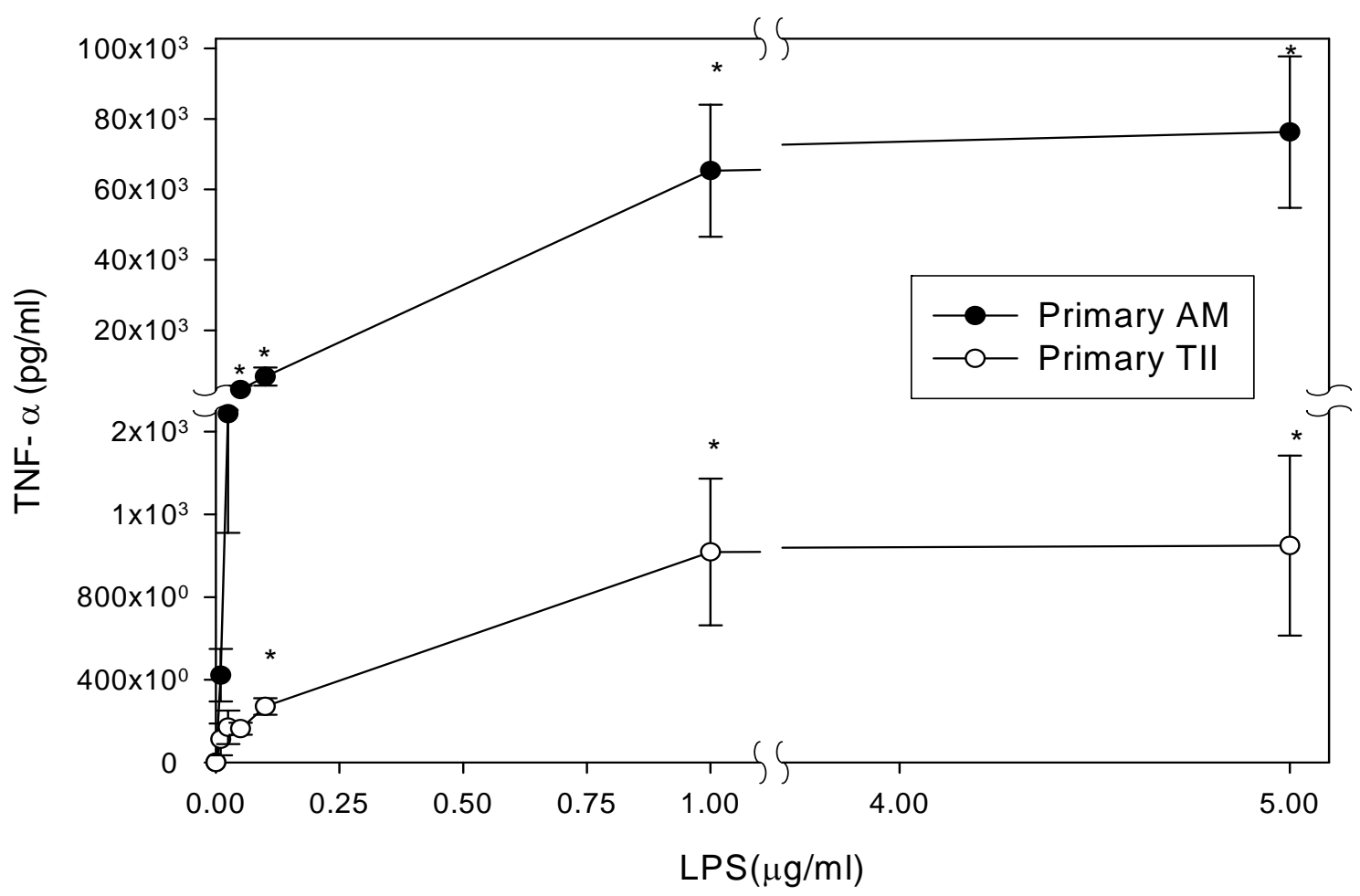


Figure 16: Exposure- induced TNF- $\alpha$ release from the 3 rat alveolar cell types upon silica exposure. $1 \times 10^{6}$ cells $/ \mathrm{ml}$ were exposed to increasing concentrations of silica for 18 hours. There was no detectable TNF- $\alpha$ release from RLE-6TN cells upon silica exposure. Values are means \pm SE of 4 experiments. * indicates a significant difference $(\mathrm{p}<0.05)$ from control (0 silica) for AM's and TII cells.

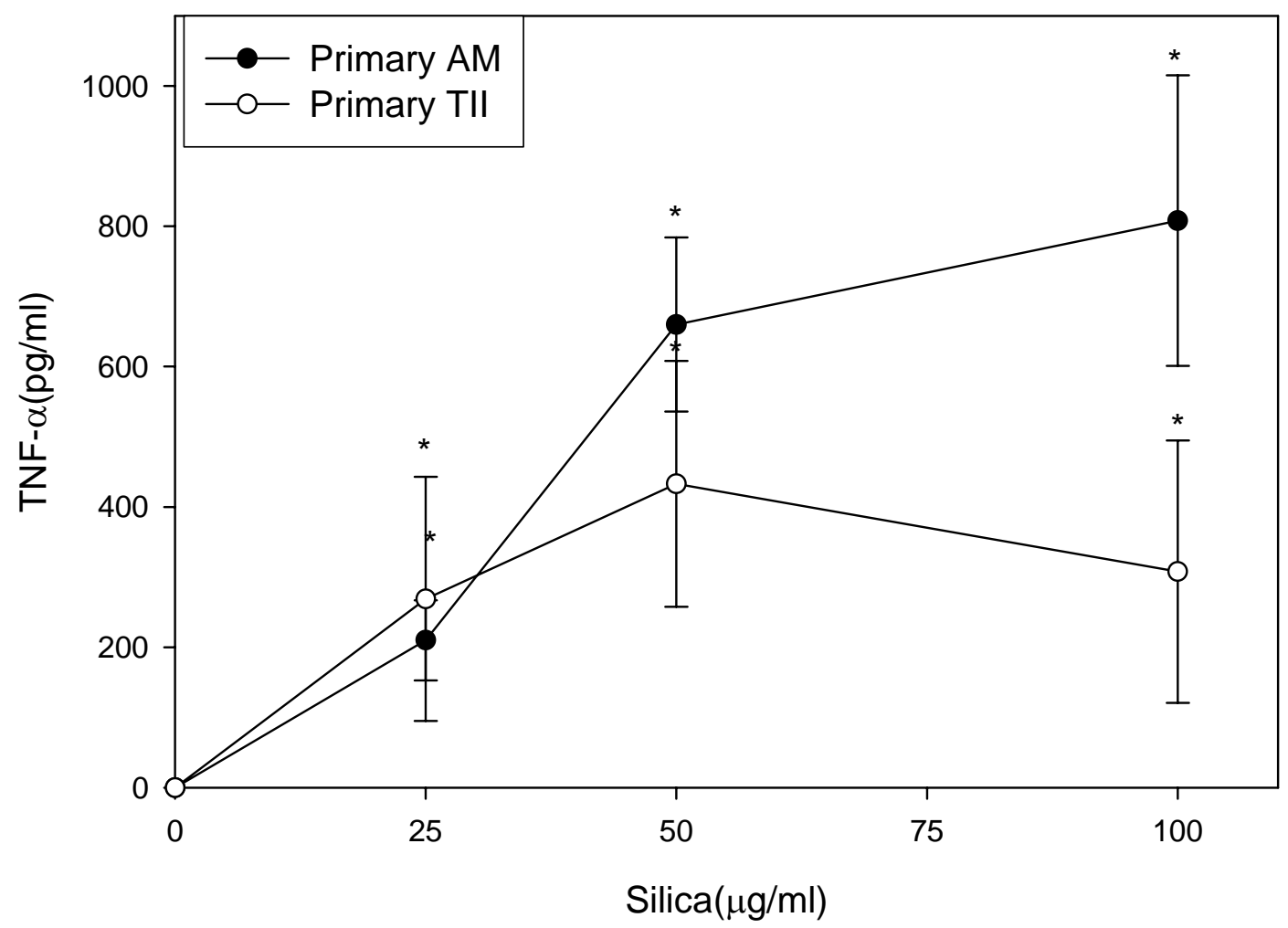


Figure 17: Exposure- induced MIP-2 release from the 3 rat alveolar cell types upon LPS exposure. $1 \times 10^{6}$ cells $/ \mathrm{ml}$ were exposed to increasing concentrations of LPS for 18 hours. Values are means $\pm \mathrm{SE}$ of 3 experiments. Note the breaks in the axes. * indicates a significant difference $(p<0.05)$ from control (0 LPS) for each cell type.

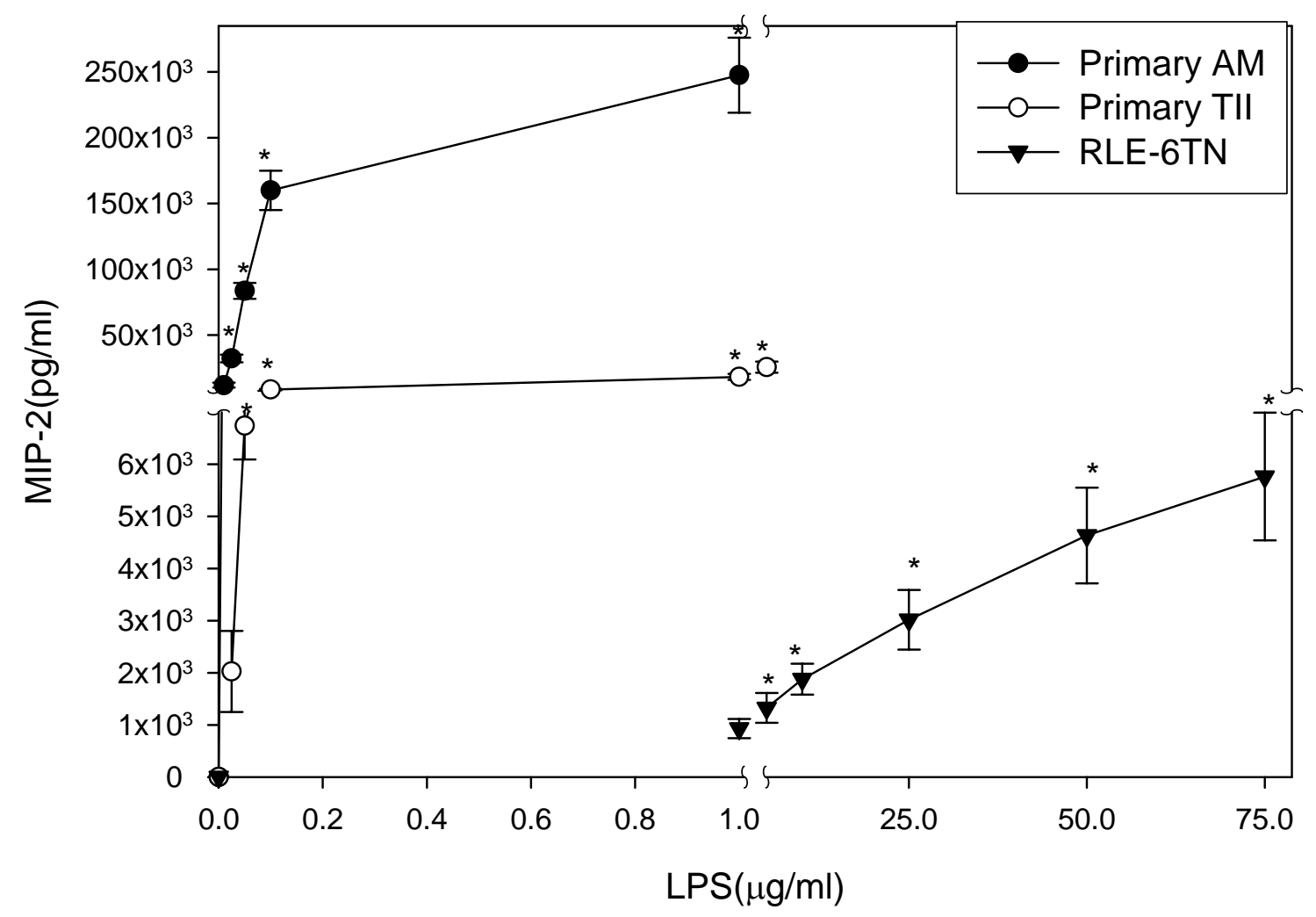


Figure 18: Exposure- induced MIP-2 release from the 3 rat alveolar cell types upon silica exposure. $1 \times 10^{6}$ cells $/ \mathrm{ml}$ were exposed to increasing concentrations of silica for 18 hours. Values are means \pm SE of 4 experiments. Note the break in the y-axis. * indicates a significant difference $(\mathrm{p}<0.05)$ from control $(0$ silica $)$ for each cell type.

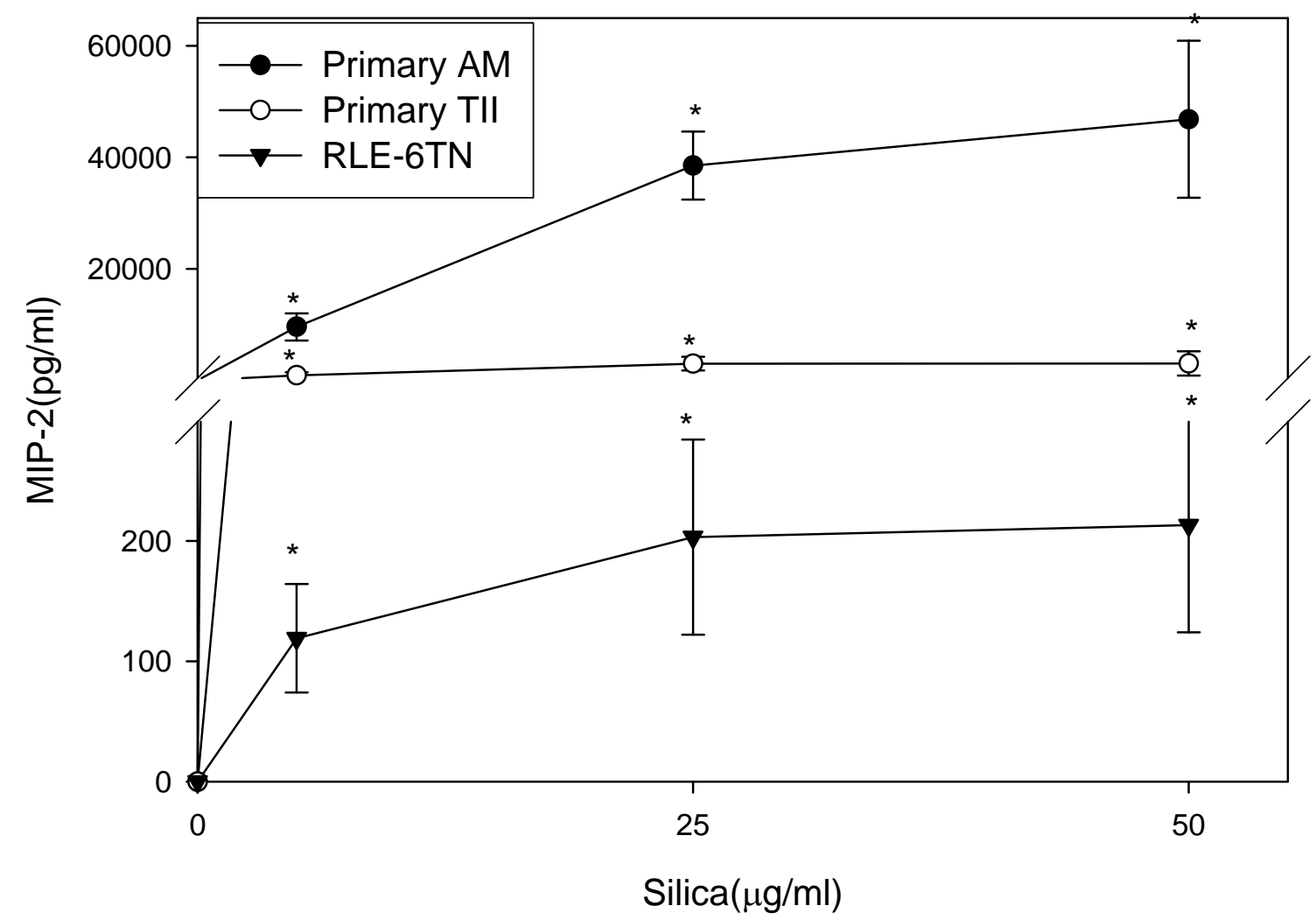


Figure 19: Exposure- induced IL-1 $\beta$ release from the 3 rat alveolar cell types upon LPS exposure. $1 \times 10^{6}$ cells $/ \mathrm{ml}$ were exposed to increasing concentrations of LPS for 18 hours. There was no detectable IL-1 $\beta$ release from RLE-6TN cells upon LPS exposure. Values are means $\pm \mathrm{SE}$ of 4 experiments. Note the break in the $\mathrm{x}$-axis. * indicates a significant difference $(p<0.05)$ from control (0 LPS) for AM's and TII cells.

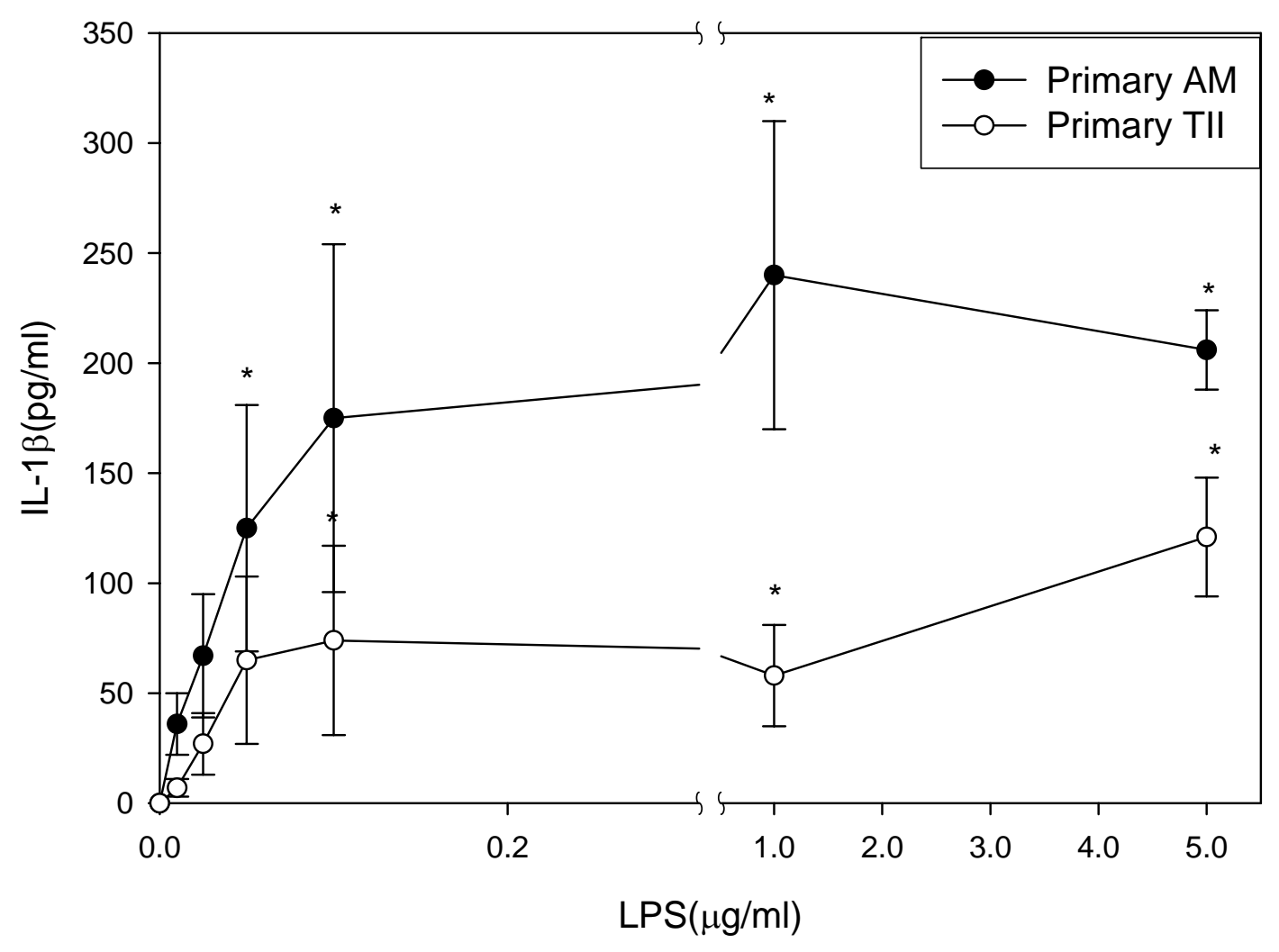


Figure 20: Exposure- induced IL-1 $\beta$ release from the 3 rat alveolar cell types upon silica exposure. $1 \times 10^{6}$ cells $/ \mathrm{ml}$ were exposed to increasing concentrations of silica for 18 hours. There was no detectable IL- $1 \beta$ release from RLE-6TN cells upon silica exposure. Values are means \pm SE of 4 experiments. $*$ indicates a significant difference $(p<0.05)$ from control (0 silica) for AM's and TII cells.

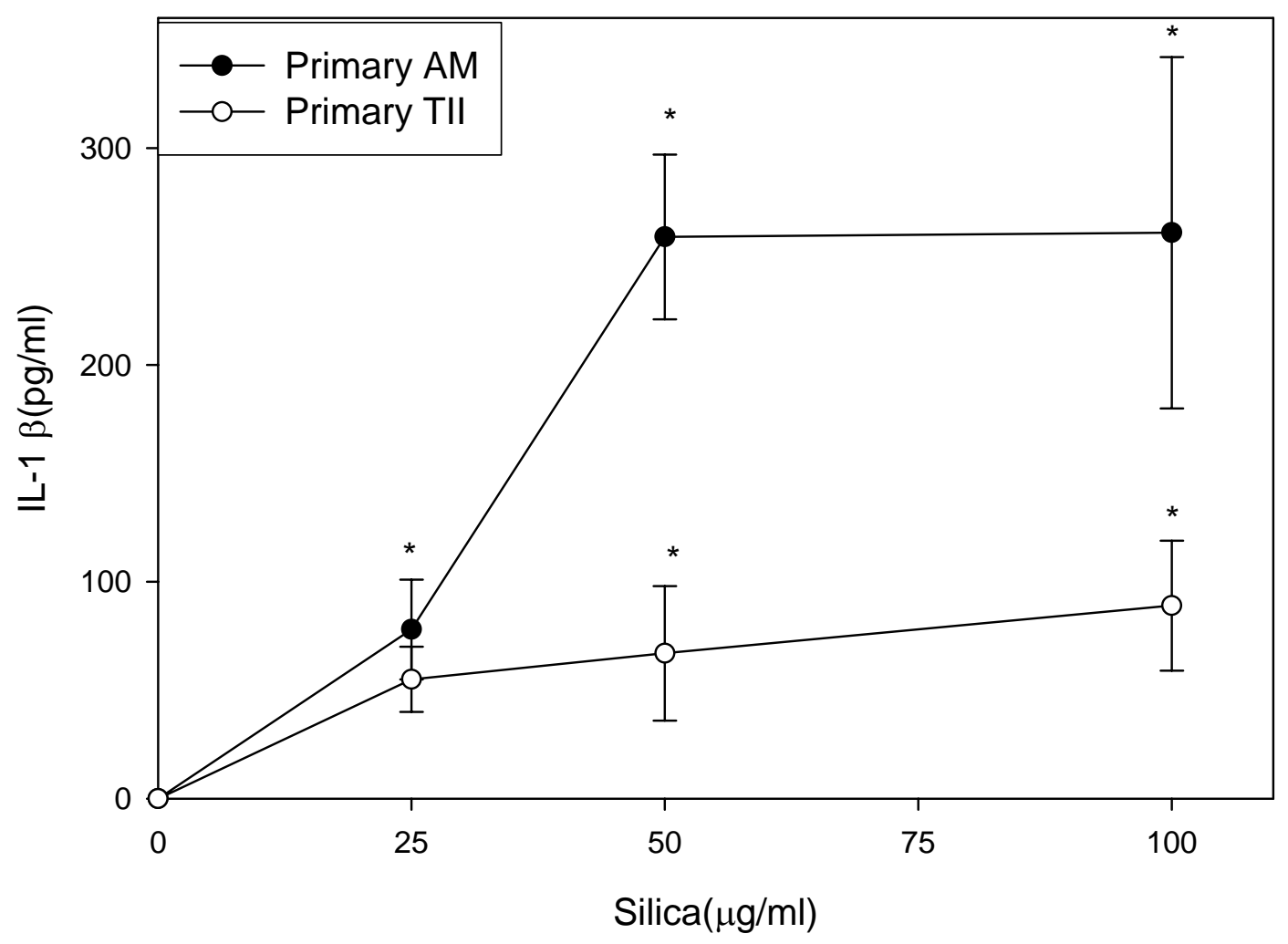


Figure 21: Exposure- induced IL-6 release from the 3 rat alveolar cell types upon LPS exposure. $1 \times 10^{6}$ cells $/ \mathrm{ml}$ were exposed to increasing concentrations of LPS for 18 hours. Values are means $\pm \mathrm{SE}$ of 3 experiments. Note the break in the $\mathrm{x}$-axis. * indicates a significant difference $(p<0.05)$ from control $(0$ LPS $)$ for each cell type.

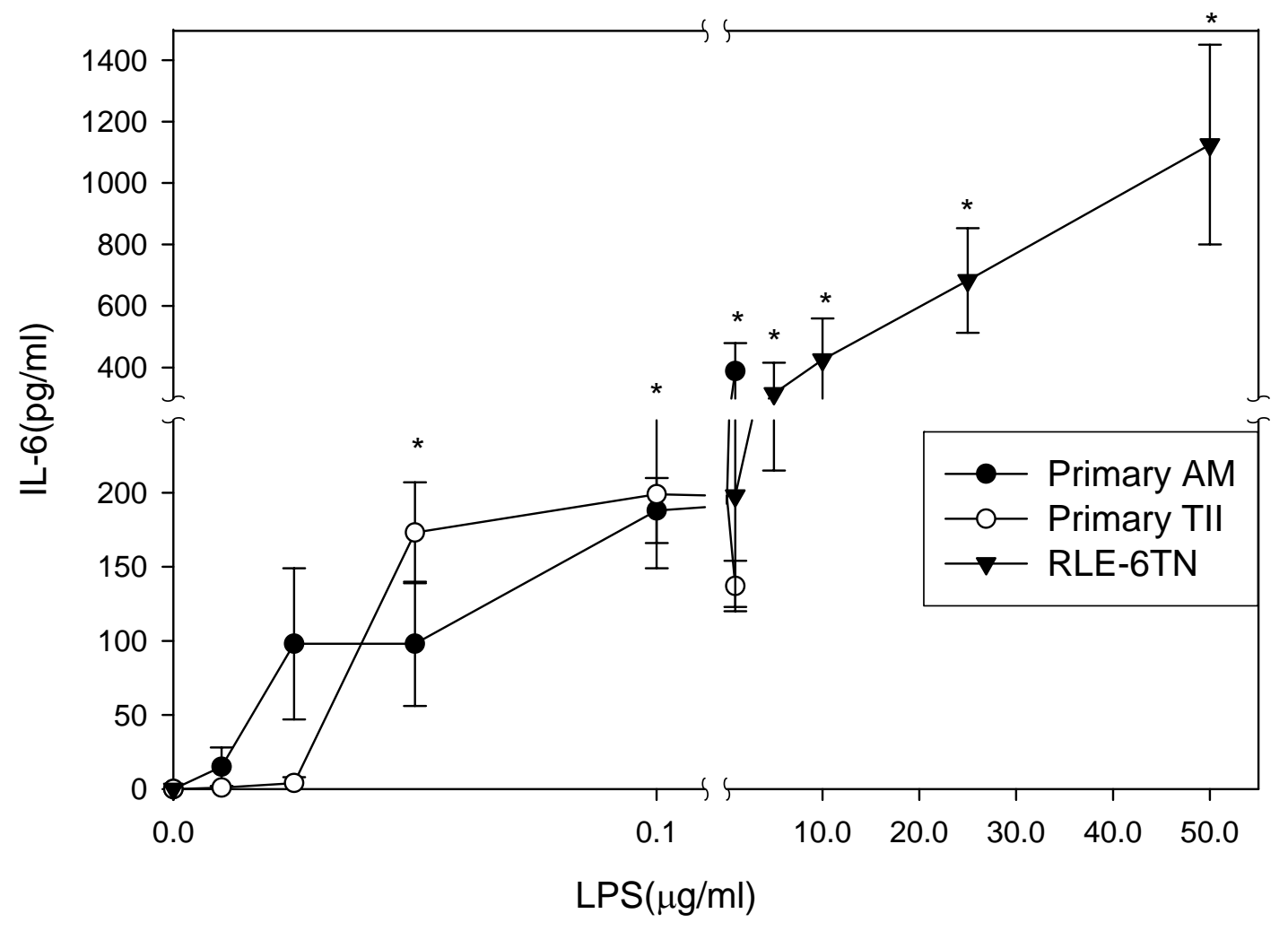


Figure 22: Exposure- induced IL-6 release from the 3 rat alveolar cell types upon silica exposure. $1 \times 10^{6}$ cells $/ \mathrm{ml}$ were exposed to increasing concentrations of silica for 18 hours. Values are means \pm SE of 4 experiments. Note the break in the $\mathrm{x}$-axis. * indicates a significant difference $(\mathrm{p}<0.05)$ from control $(0$ silica $)$ for each cell type.

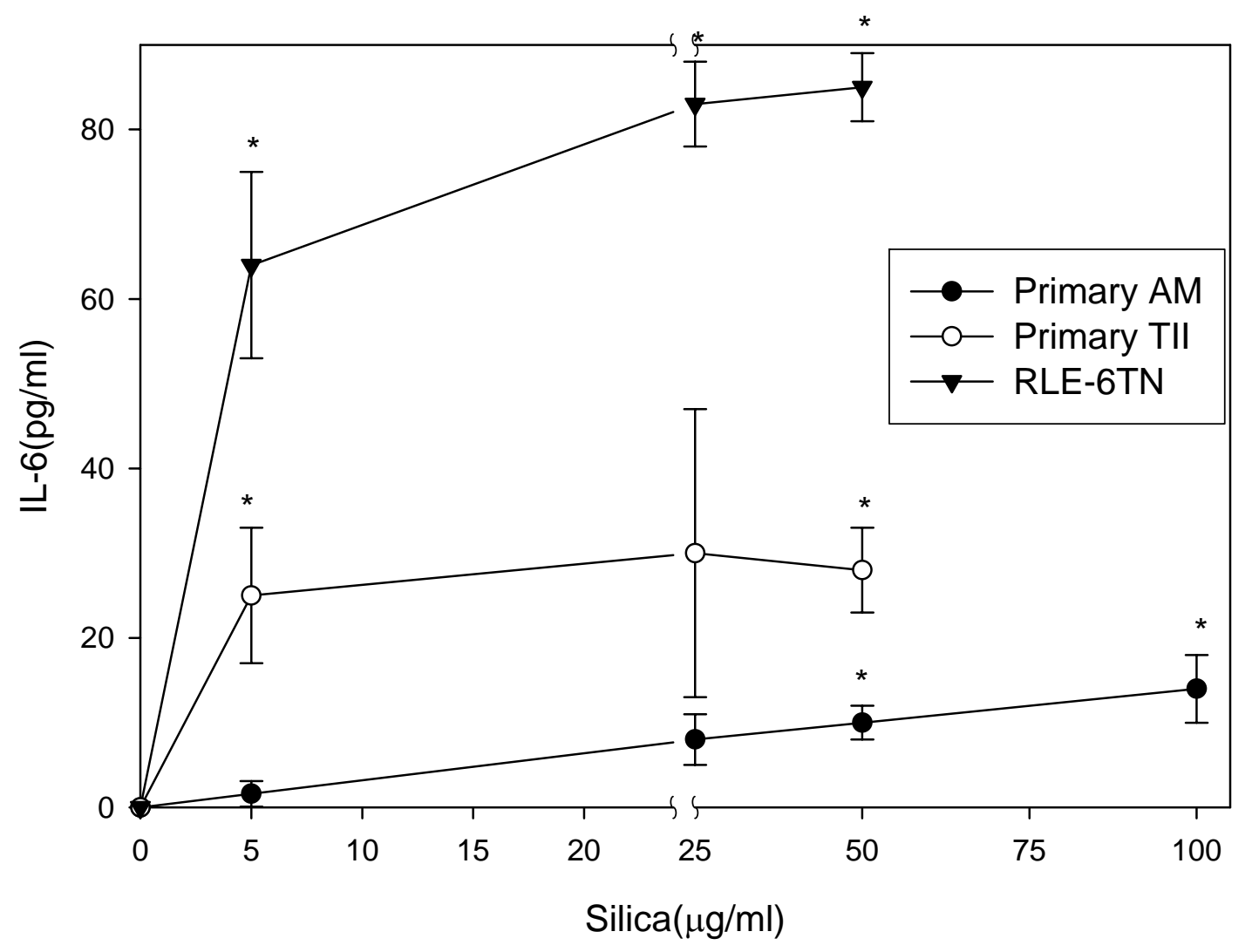


Figure 23: Exposure- induced $\mathrm{O}_{2}^{-}$release (measured by cytochrome $\mathrm{C}$ reduction) from AM's upon silica exposure. $2 \times 10^{6} \mathrm{cells} / \mathrm{ml}$ were exposed to increasing concentrations of silica for 30 minutes. Values are means $\pm \mathrm{SE}$ of 4 experiments. $*$ indicates a significant difference $(p<0.05)$ from control ( 0 silica).

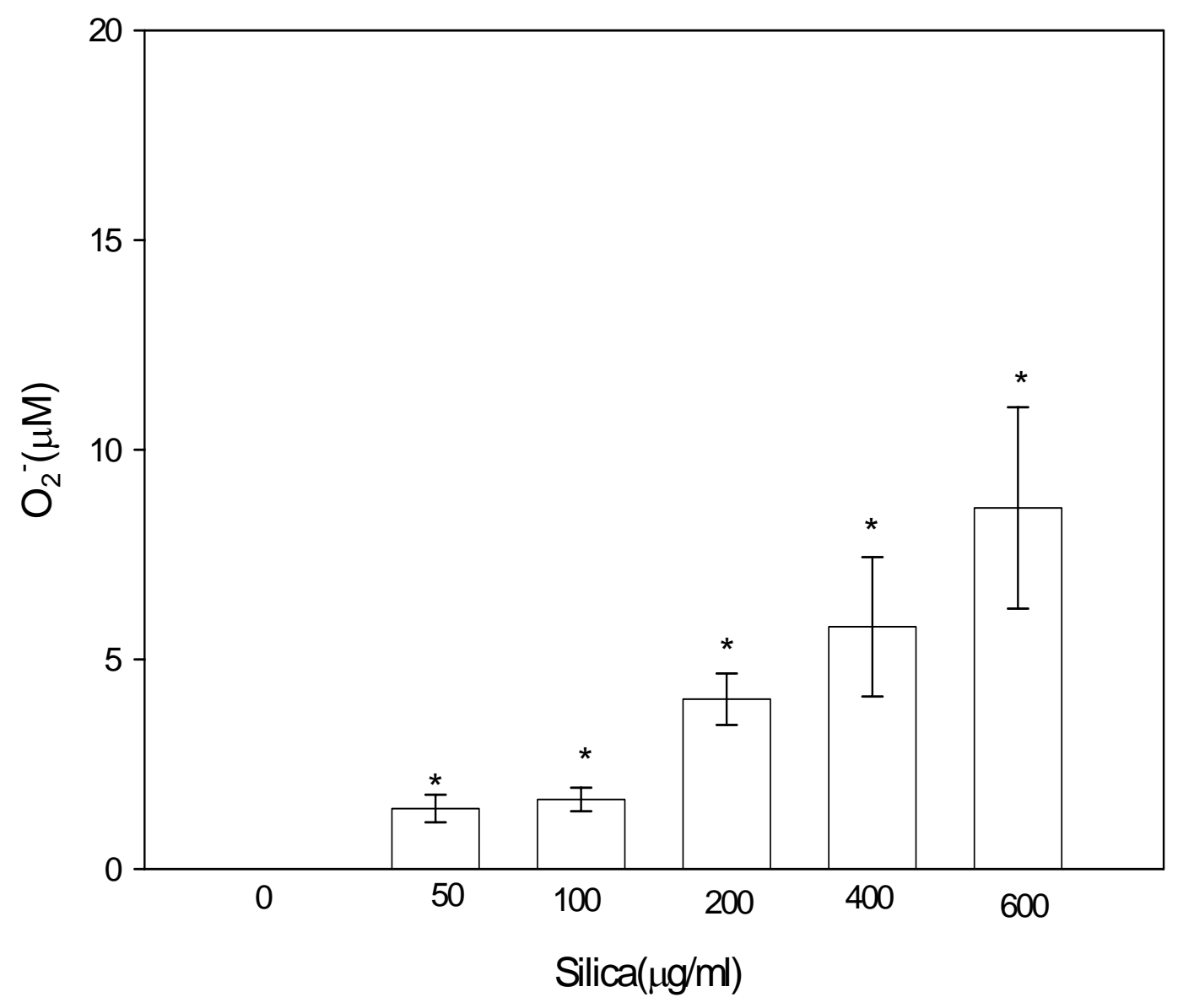


Figure 24: Exposure- induced $\mathrm{O}_{2}^{-}$release (measured by cytochrome $\mathrm{C}$ reduction) from TII cells upon silica exposure. $2 \times 10^{6}$ cells $/ \mathrm{ml}$ were exposed to increasing concentrations of silica for 30 minutes. Values are means $\pm \mathrm{SE}$ of 4 experiments. $*$ indicates a significant difference $(\mathrm{p}<0.05)$ from control ( 0 silica).

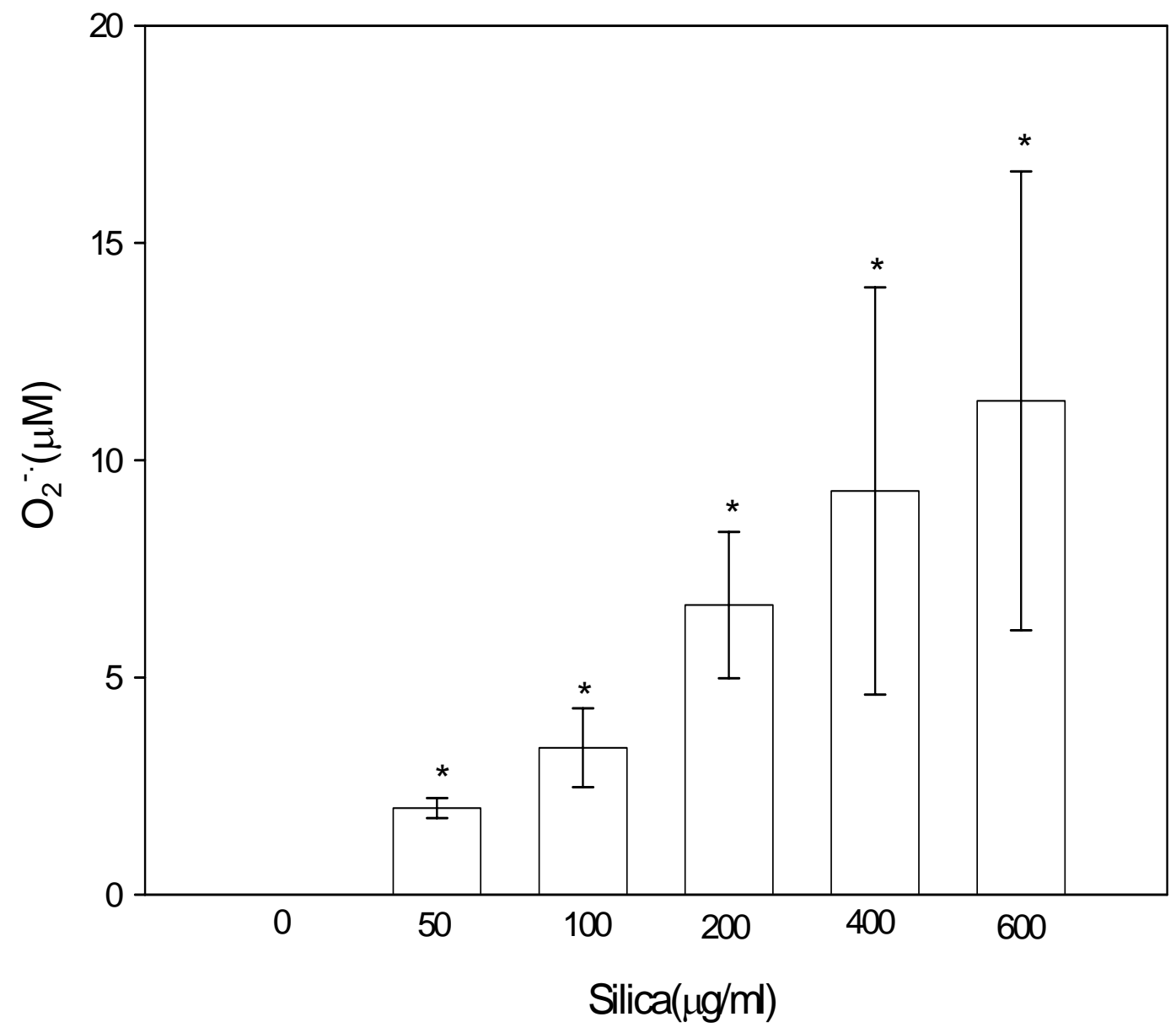


Figure 25: Exposure- induced $\mathrm{O}_{2}{ }^{-}$release (measured by cytochrome $\mathrm{C}$ reduction) from RLE-6TN cells upon silica exposure. $2 \times 10^{6}$ cells $/ \mathrm{ml}$ were exposed to increasing concentrations of silica for 30 minutes. Values are means \pm SE of 4 experiments. * indicates a significant difference $(\mathrm{p}<0.05)$ from control $(0$ silica $)$.

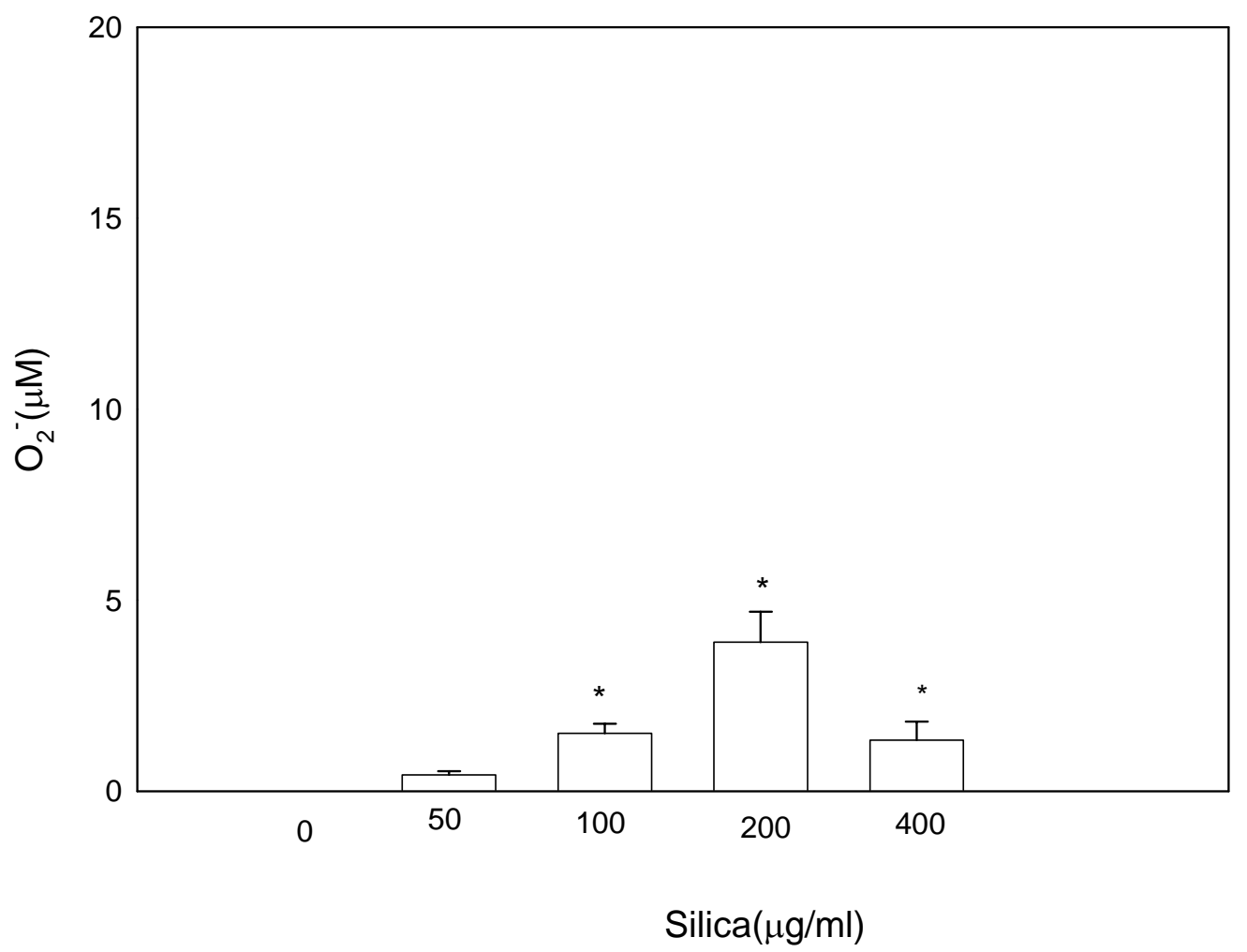


Figure 26: Exposure- induced ROS (measured by luminol-dependent chemiluminescence) release from AM's upon LPS exposure. $2 \times 10^{6}$ cells $/ \mathrm{ml}$ were exposed to increasing concentrations of LPS for 30 minutes. Values are means $\pm \mathrm{SE}$ of 4 experiments. * indicates a significant difference $(p<0.05)$ from control (0 LPS). Chemiluminescence: CL; Relative light units: RLU

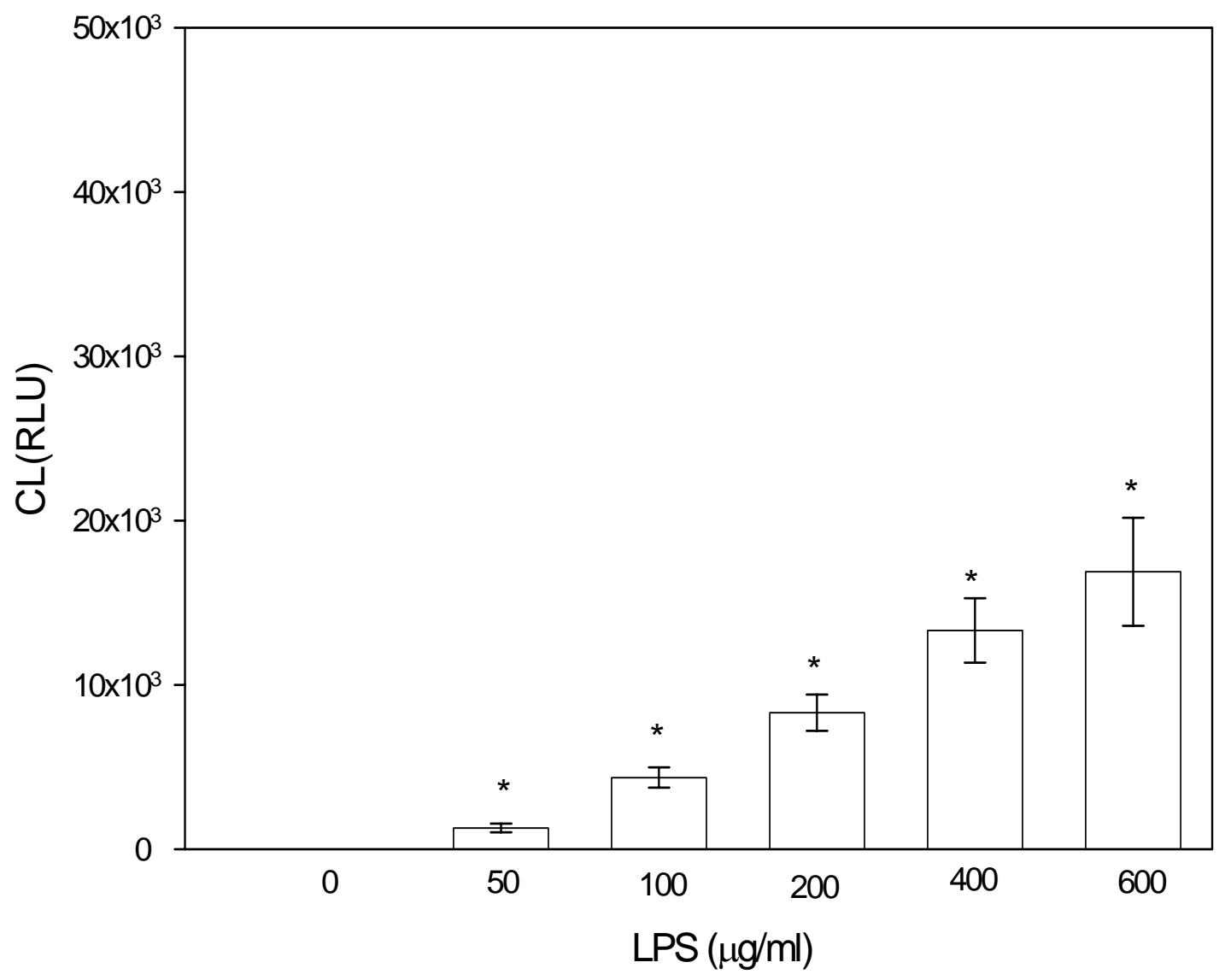


Figure 27: Confocal microscopy of AM's with dihydroethydium dye (indicator of ROS) upon LPS exposure. $2 \times 10^{6} \mathrm{cells} / \mathrm{ml}$ were exposed to $600 \mu \mathrm{g} / \mathrm{ml}$ LPS for 30 minutes.
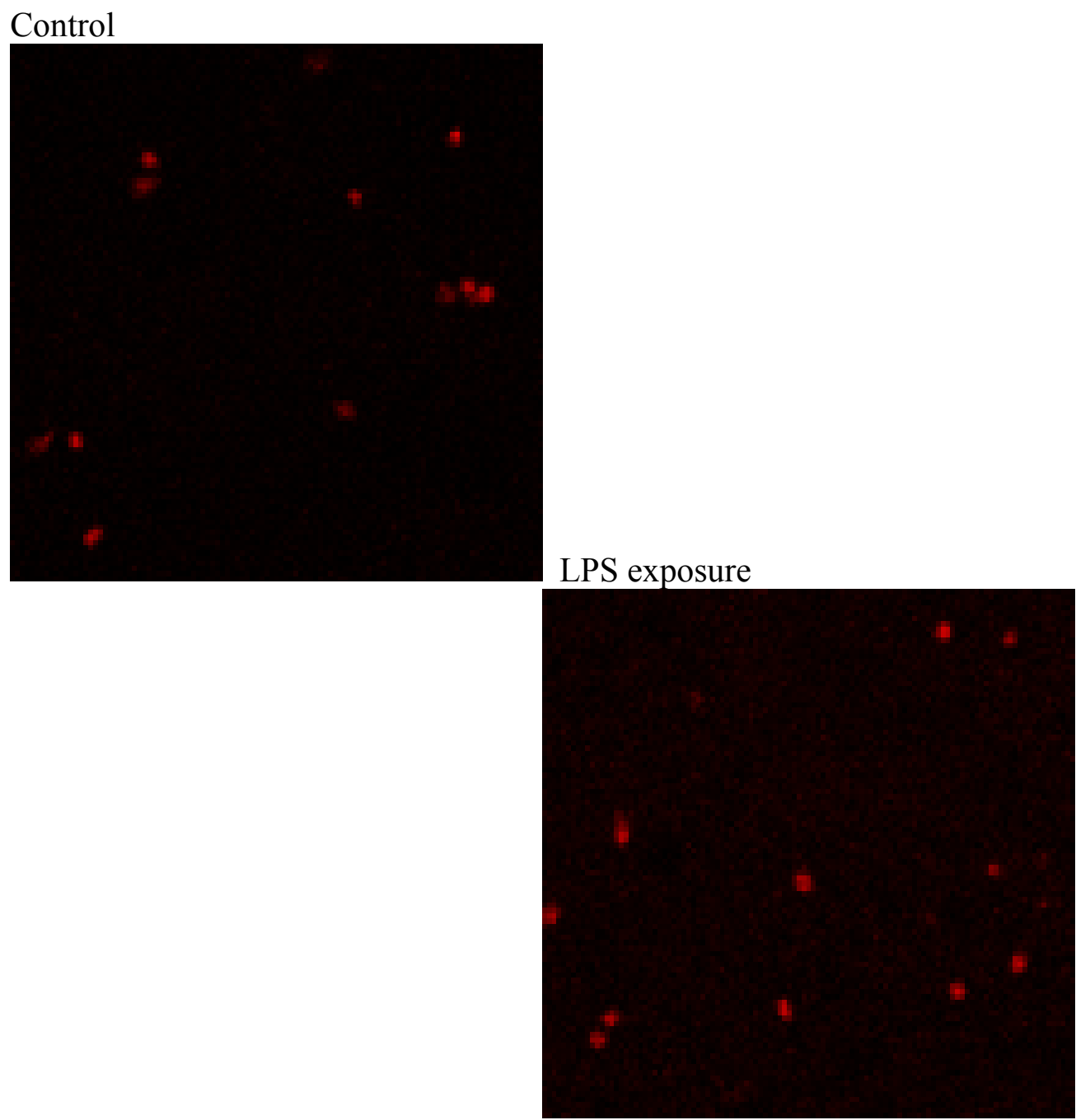
Figure 28: Exposure- induced ROS (measured by luminol-dependent chemiluminescence) release from the AM's upon silica exposure. $2 \times 10^{6}$ cells $/ \mathrm{ml}$ were exposed to increasing concentrations of silica for 30 minutes. Values are means $\pm \mathrm{SE}$ of 7 experiments. * indicates a significant difference $(\mathrm{p}<0.05)$ from control $(0$ silica $)$. Chemiluminescence: CL; Relative light units: RLU

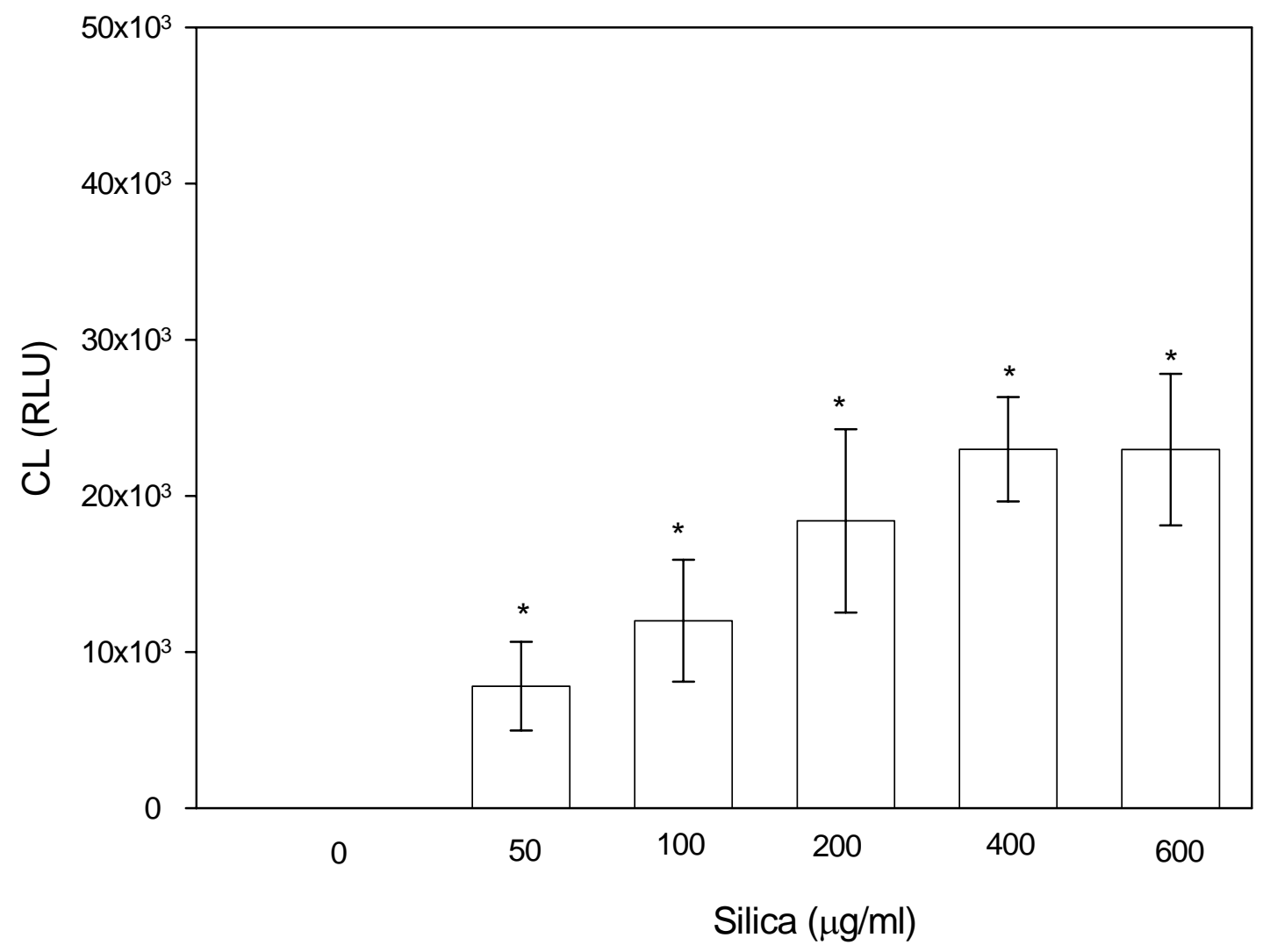


Figure 29 : Confocal microscopy of AM's with dihydroethydium dye (indicator of ROS) upon silica exposure. $2 \times 10^{6}$ cells $/ \mathrm{ml}$ were exposed to $600 \mu \mathrm{g} / \mathrm{ml}$ silica for 30 minutes.

\section{Control}

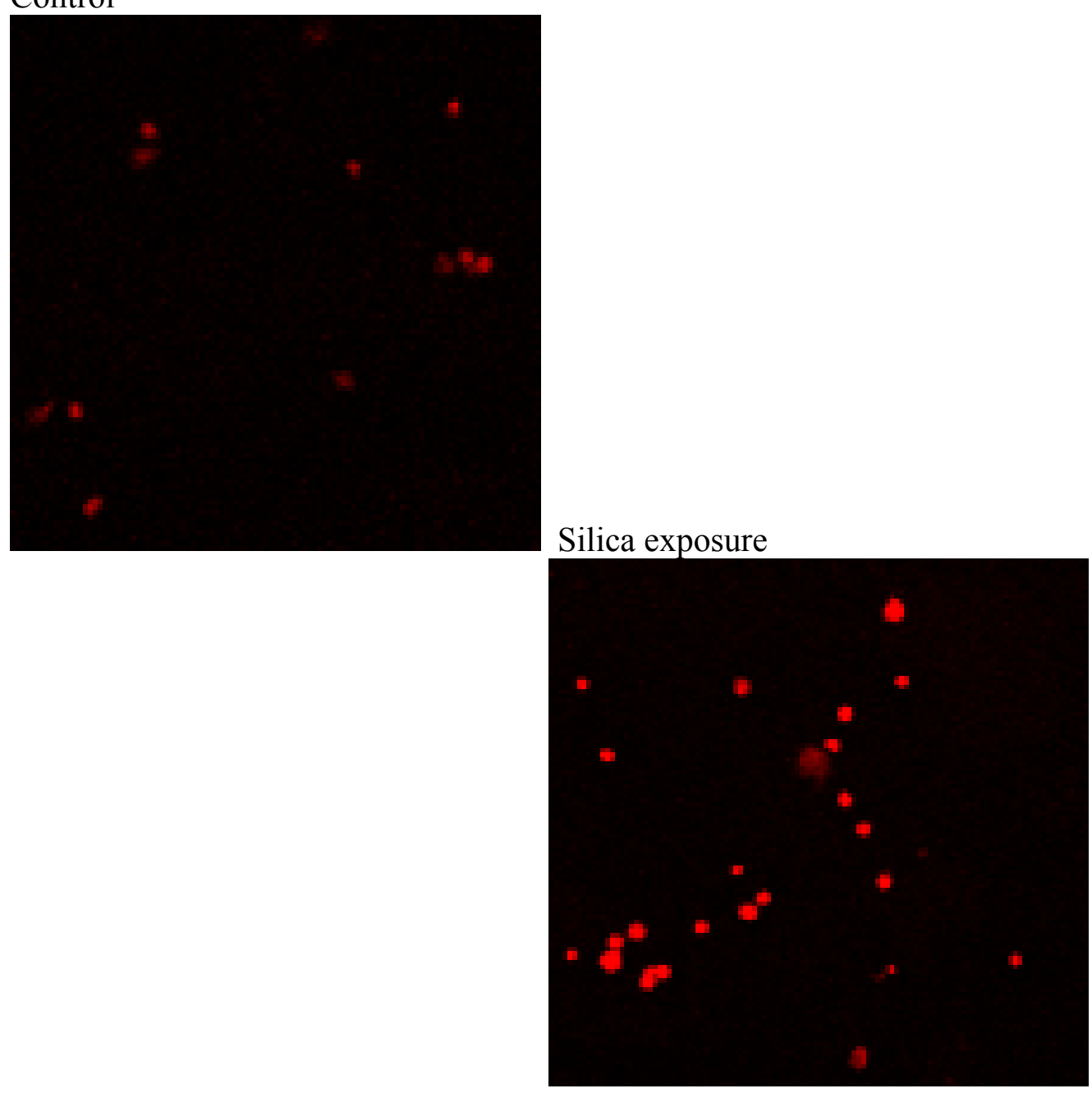


Figure 30: Exposure- induced ROS (measured by luminol-dependent chemiluminescence) release from primary rat TII cells upon silica exposure. $2 \times 10^{6}$ cells / $\mathrm{ml}$ were exposed to increasing concentrations of silica for 30 minutes. Values are means \pm SE of 4 experiments. * indicates a significant difference $(p<0.05)$ from control $(0$ silica).

Chemiluminescence: CL; Relative light units: RLU

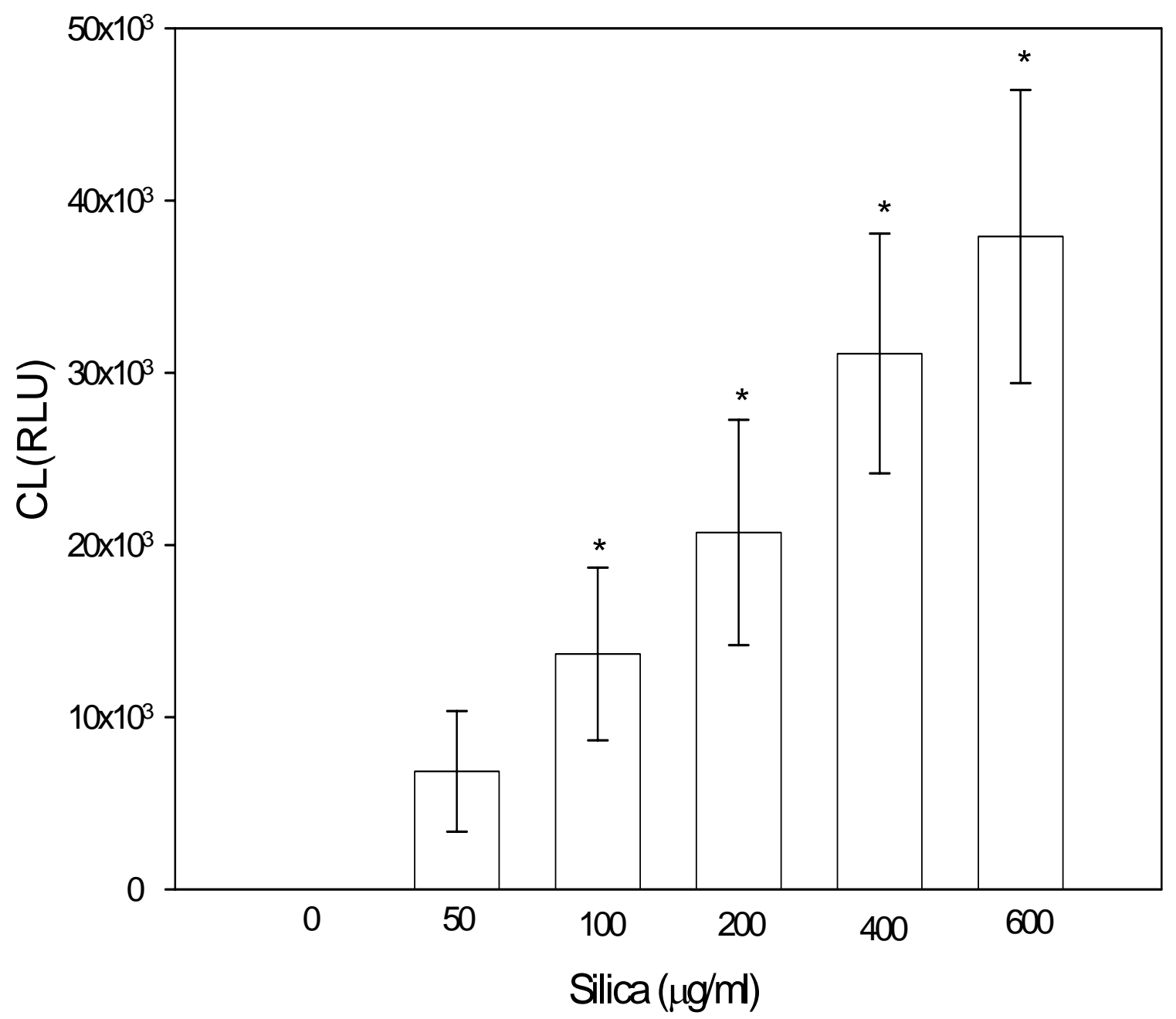


Figure 31: Confocal microscopy of primary rat TII cells with dihydroethydium dye (indicator of ROS) upon silica exposure. $2 \times 10^{6}$ cells $/ \mathrm{ml}$ were exposed to $600 \mu \mathrm{g} / \mathrm{ml}$ silica for 30 minutes.

\section{Control}


Figure 32: TNF- $\alpha$ release in mixed AM/TII co-culture, transwell AM/TII co-culture, or $\mathrm{AM}$ and TII monocultures. AM and primary TII cell concentration used in all cases was $0.25 \times 10^{6}$ cells $/ \mathrm{ml}$, exposure time was 18 hours. Values are means $\pm \mathrm{SE}$ of 4 experiments. * indicates a significant difference $(\mathrm{p}<0.05)$ between AM/TII transwell co-culture and the sum of the separate cultures(AM+TII). + indicates a significant difference $(p<0.05)$ between mixed and transwell co-cultures.

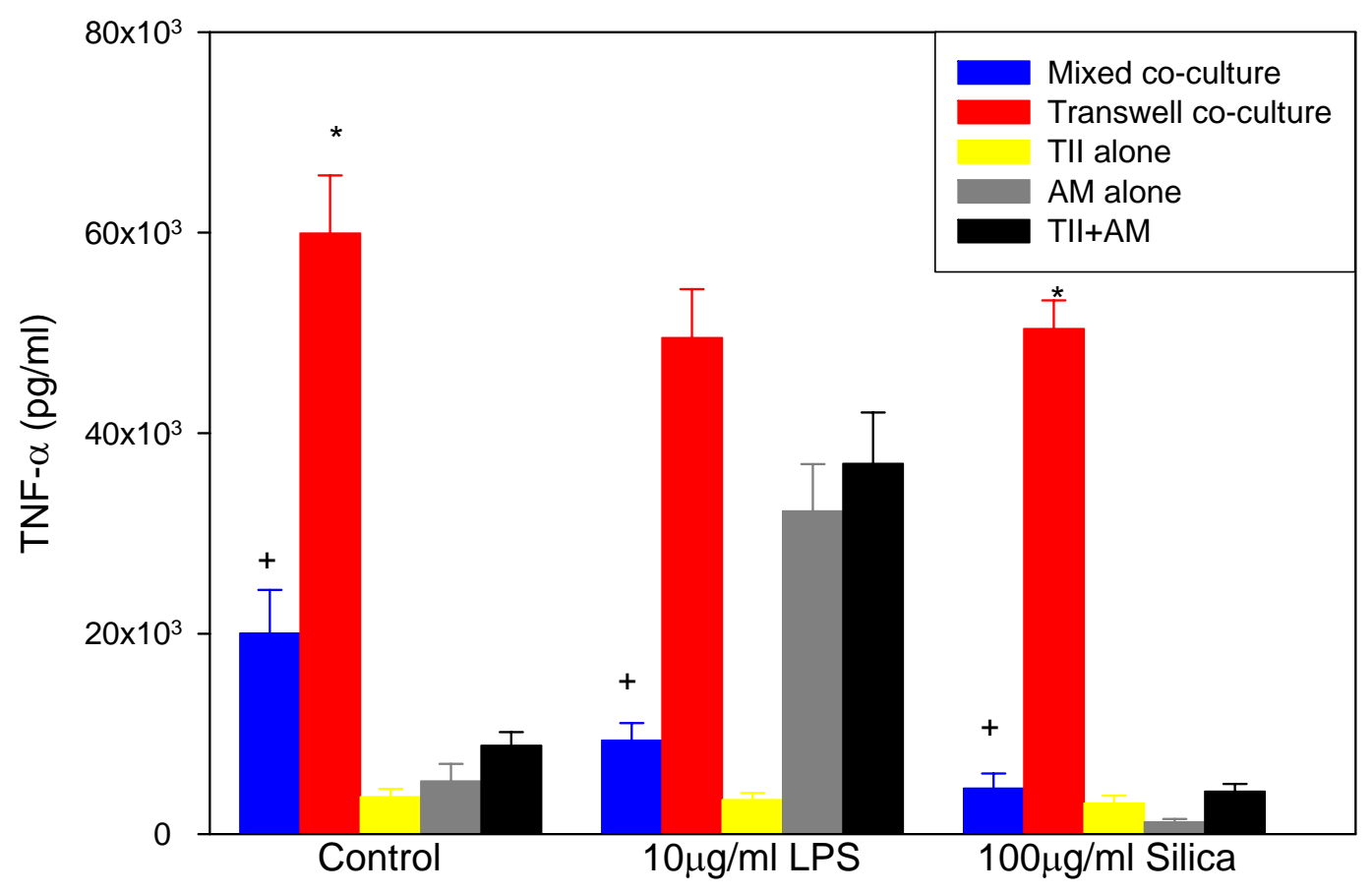


Figure 33: TNF- $\alpha$ potentiation (value in the mixed co-culture system minus value of the sum of the separate cell cultures) upon adding $0.8 \mathrm{mg} / \mathrm{ml}$ fibrinogen (a surfactant inhibitor) to AM/TII basal mixed co-culture versus TNF- $\alpha$ potentiation without adding fibrinogen (control). AM and TII cell concentration used in all cases was $0.25 \times 10^{6}$ cells/ml, exposure time was 18 hours. Values are means \pm SE of 4 experiments. * indicates a significant increase in the mediator potentiation upon adding fibrinogen.

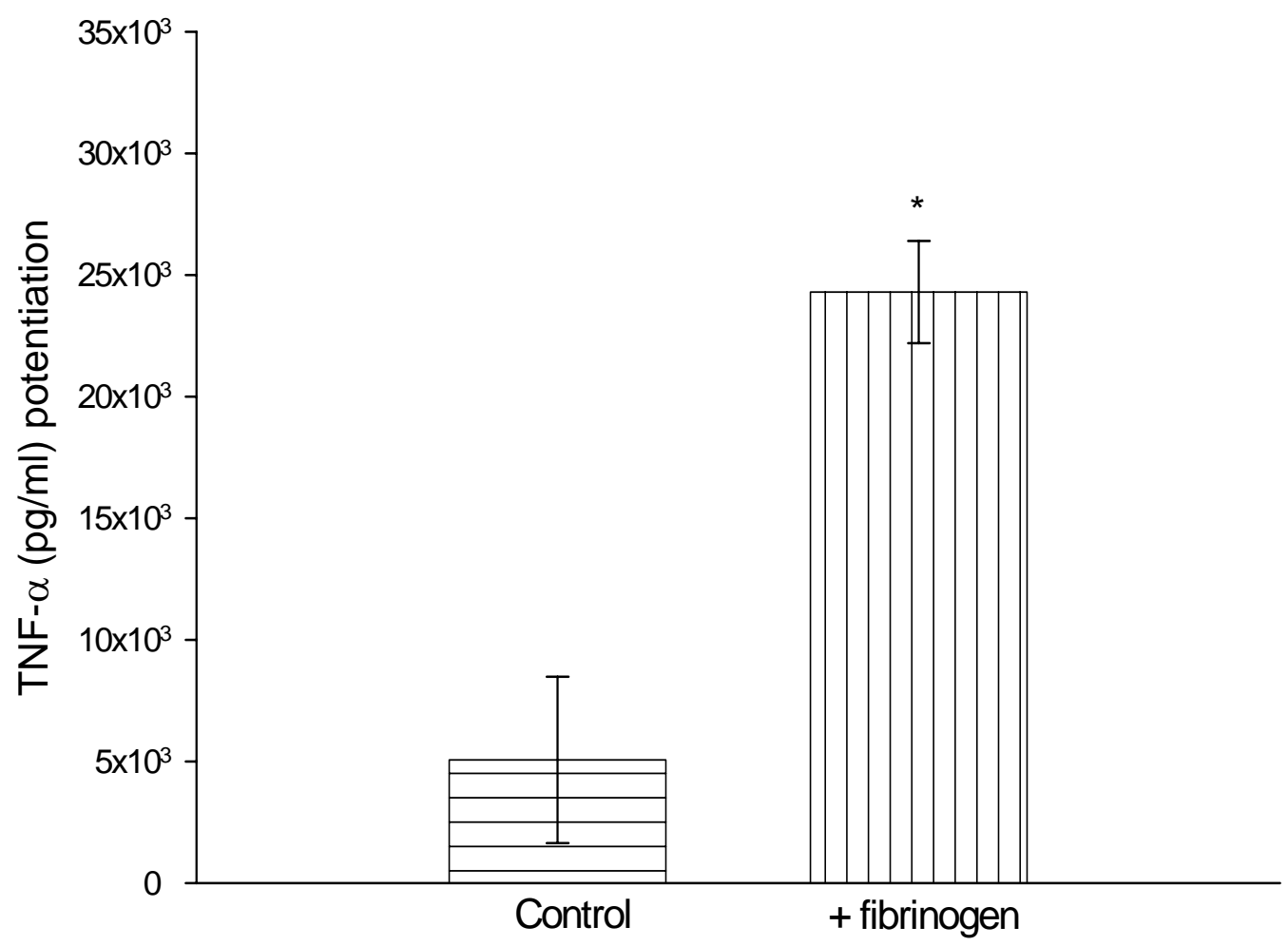


Figure 34: MIP-2 release in mixed AM/TII co-culture, transwell AM/TII co-culture, or AM and TII monocultures. AM and TII cell concentration used in all cases was 0 . $25 \times 10^{6}$ cells $/ \mathrm{ml}$, exposure time was 18 hours. Values are means \pm SE of 4 experiments. $*$ indicates a significant difference $(\mathrm{p}<0.05)$ between AM/TII transwell co-culture and the sum of the separate cultures $(\mathrm{AM}+\mathrm{TII}) .+$ indicates a significant difference $(\mathrm{p}<0.05)$ between mixed and transwell co-cultures.

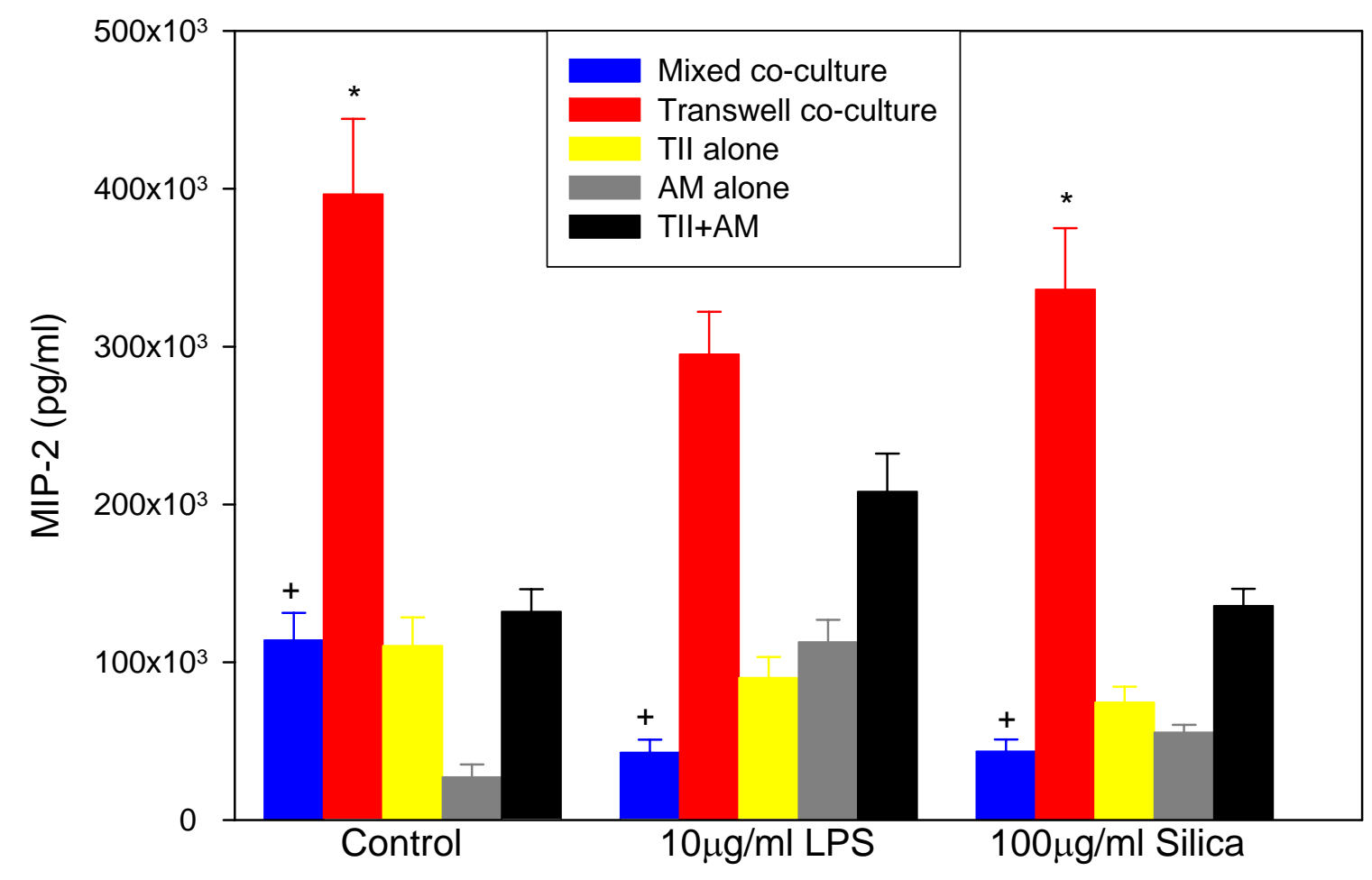


Figure 35: MIP-2 potentiation (value in the mixed co-culture system minus value of the sum of the separate cell cultures) upon adding $0.8 \mathrm{mg} / \mathrm{ml}$ fibrinogen (a surfactant inhibitor) to AM/TII basal mixed co-culture versus MIP-2 potentiation without adding fibrinogen (control). AM and TII cell concentration used in all cases was $0.25 \times 10^{6}$ cells $/ \mathrm{ml}$, exposure time was 18 hours. Values are means $\pm \mathrm{SE}$ of 4 experiments. indicates a significant increase in the mediator potentiation upon adding fibrinogen.

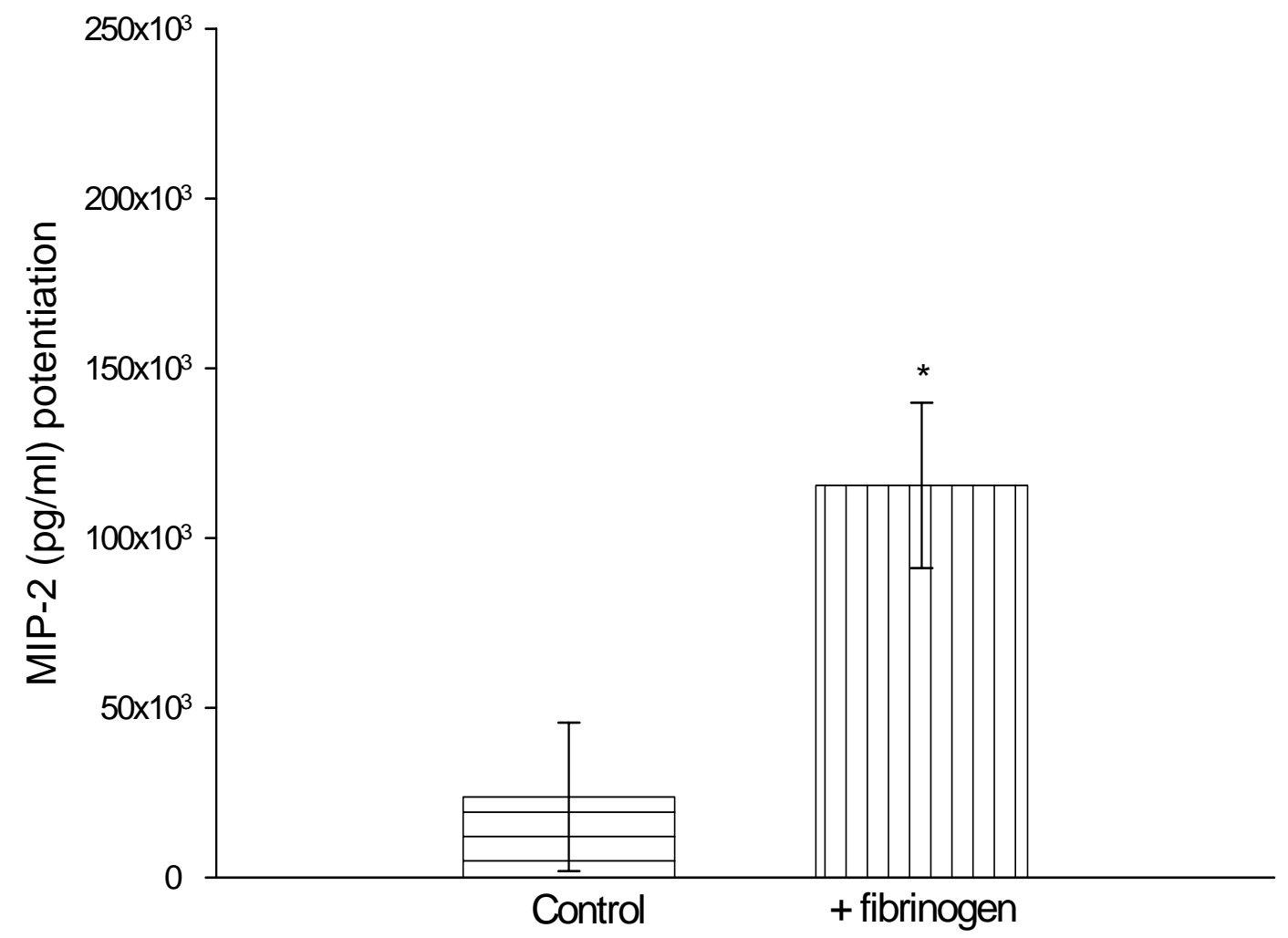


Figure 36: NO release in mixed AM/TII co-culture, transwell AM/TII co-culture, or $\mathrm{AM}$ and TII monocultures. AM and TII cell concentration used in all cases was 0 . $25 \times 10^{6}$ cells $/ \mathrm{ml}$, exposure time was 18 hours. Values are means \pm SE of 4 experiments. * indicates a significant difference $(\mathrm{p}<0.05)$ between $\mathrm{AM} / \mathrm{TII}$ transwell co-culture and the sum of the separate cultures $(\mathrm{AM}+\mathrm{TII})$. + indicates a significant difference $(\mathrm{p}<0.05)$ between mixed and transwell co-cultures.

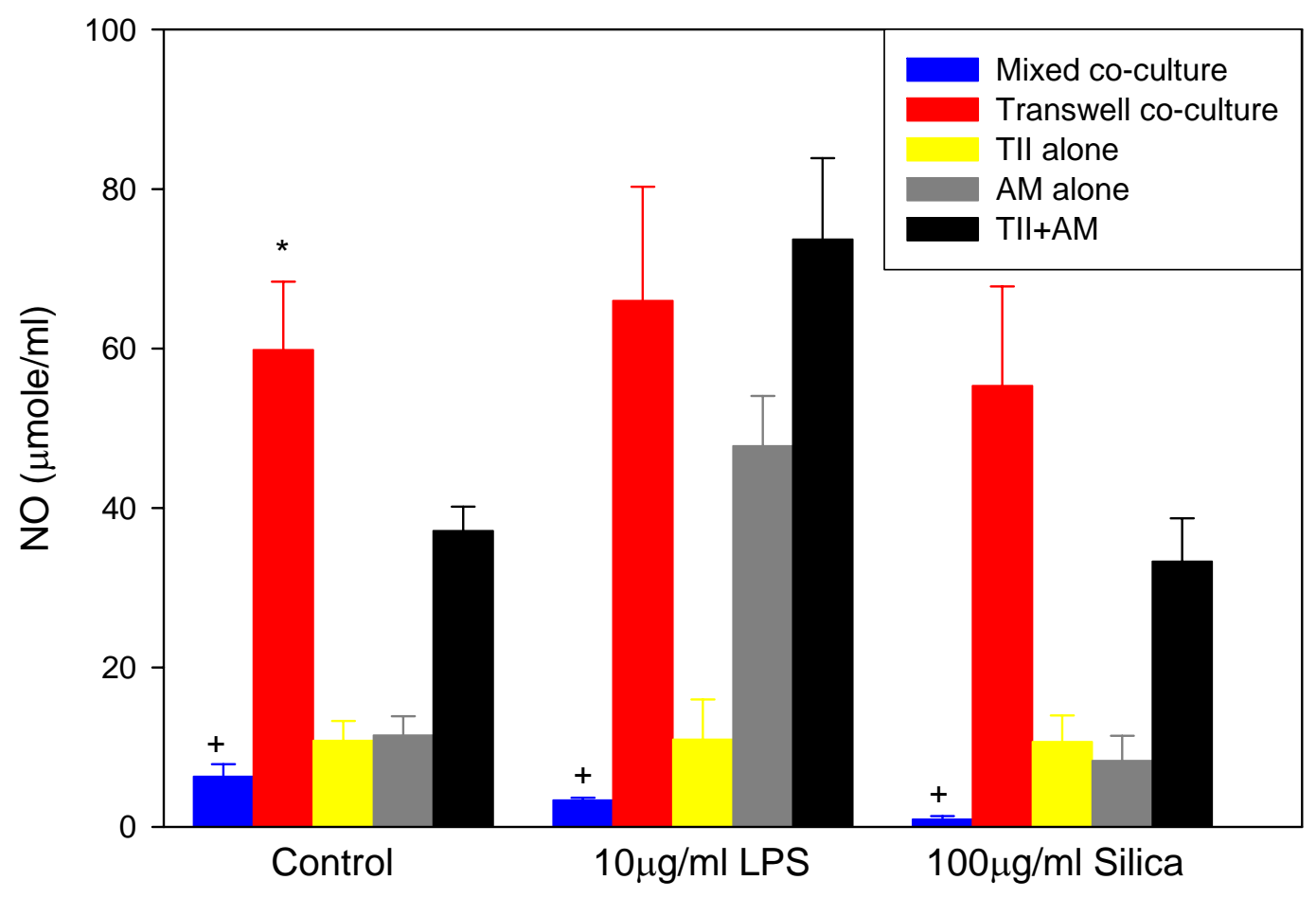


Figure 37: NO potentiation (value in the mixed co-culture system minus value of the sum of the separate cell cultures) upon adding $0.8 \mathrm{mg} / \mathrm{ml}$ fibrinogen (a surfactant inhibitor) to $\mathrm{AM} / \mathrm{TII}$ basal mixed co-culture versus NO potentiation without adding fibrinogen (control). AM and TII cell concentration used in all cases was $0.25 \times 10^{6}$ cells $/ \mathrm{ml}$, exposure time was 18 hours. Values are means \pm SE of 4 experiments. * indicates a significant reversal of mediator inhibition upon adding fibrinogen.

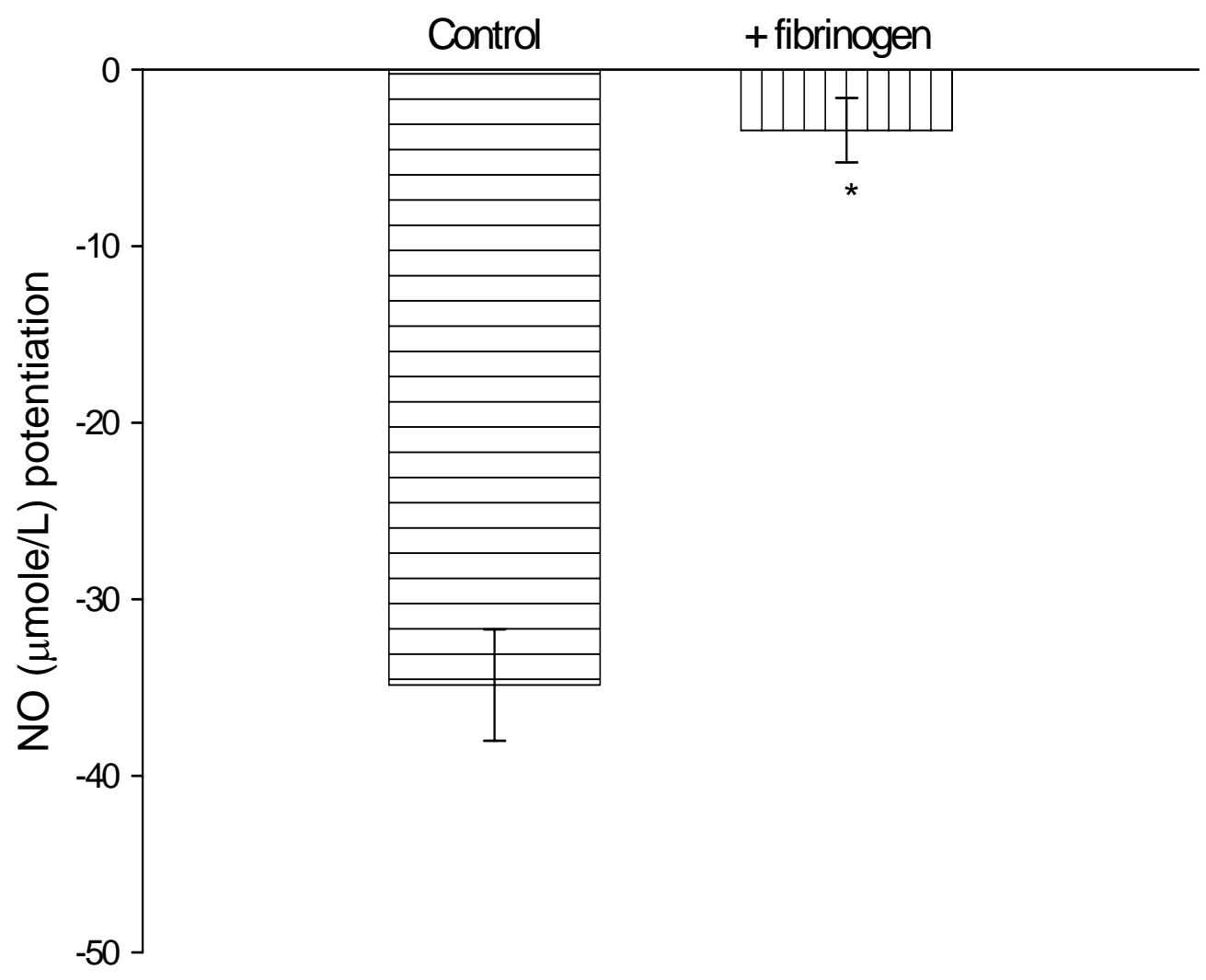


Figure 38: IL-1 $\beta$ release in mixed AM/TII co-culture, transwell AM/TII co-culture, or AM and TII monocultures. AM and TII cell concentration used in all cases was 0 . $25 \times 10^{6}$ cells $/ \mathrm{ml}$; exposure time was 18 hours. Values are means $\pm \mathrm{SE}$ of 4 experiments. $*$ indicates a significant difference $(\mathrm{p}<0.05)$ between AM/TII transwell co-culture and the sum of the separate cultures $(\mathrm{AM}+\mathrm{TII}) .+$ indicates a significant difference $(\mathrm{p}<0.05)$ between mixed and transwell co-cultures.

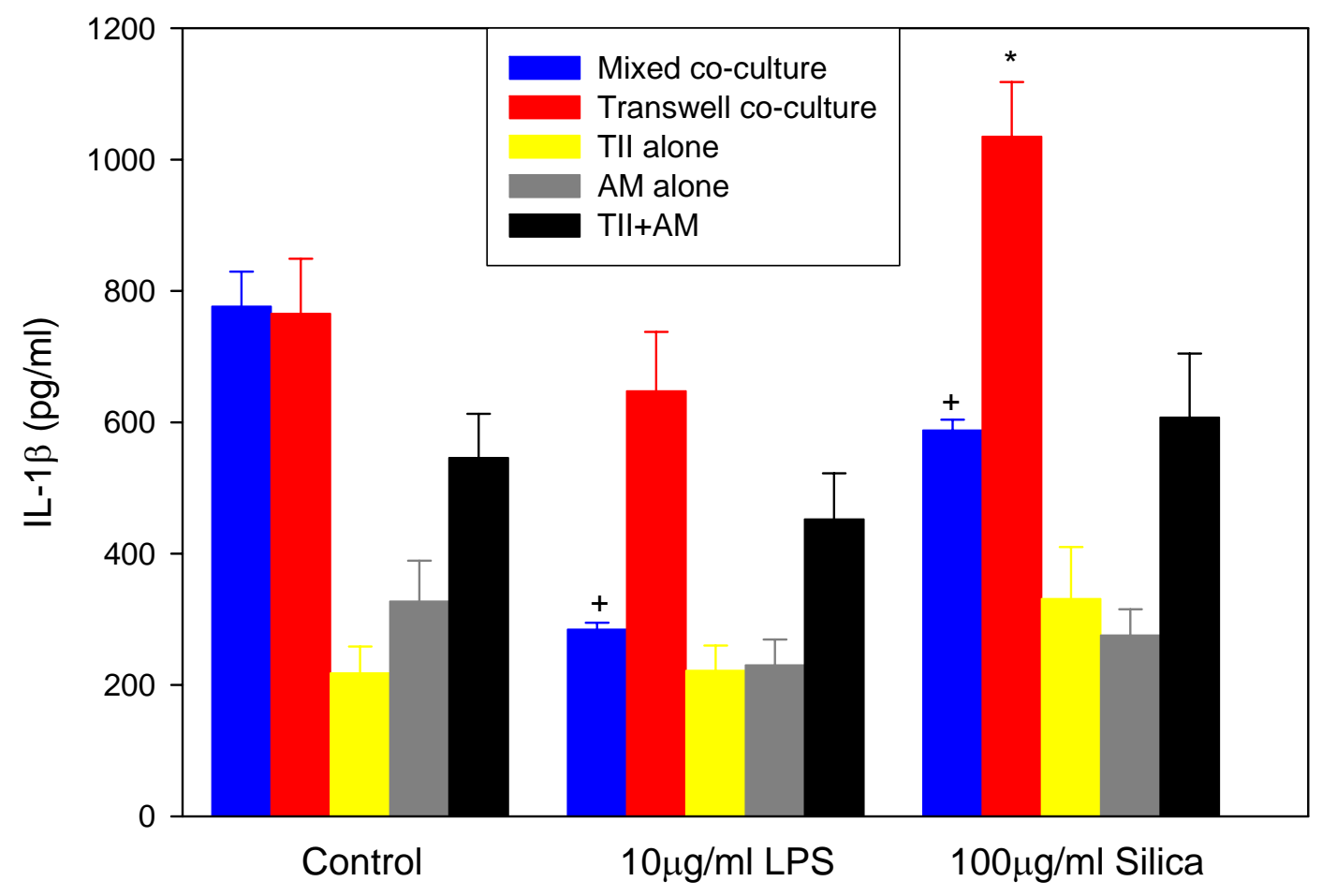


Figure 39: IL-1 $\beta$ potentiation (value in the mixed co-culture system minus value of the sum of the separate cell cultures) upon adding $0.8 \mathrm{mg} / \mathrm{ml}$ fibrinogen (a surfactant inhibitor) to AM/TII basal mixed co-culture versus IL-1 $\beta$ potentiation without adding fibrinogen (control). AM and TII cell concentration used in all cases was $0.25 \times 10^{6}$ cells/ml, exposure time was 18 hours. Values are means \pm SE of 4 experiments. * indicates a significant increase in the mediator potentiation upon adding fibrinogen.

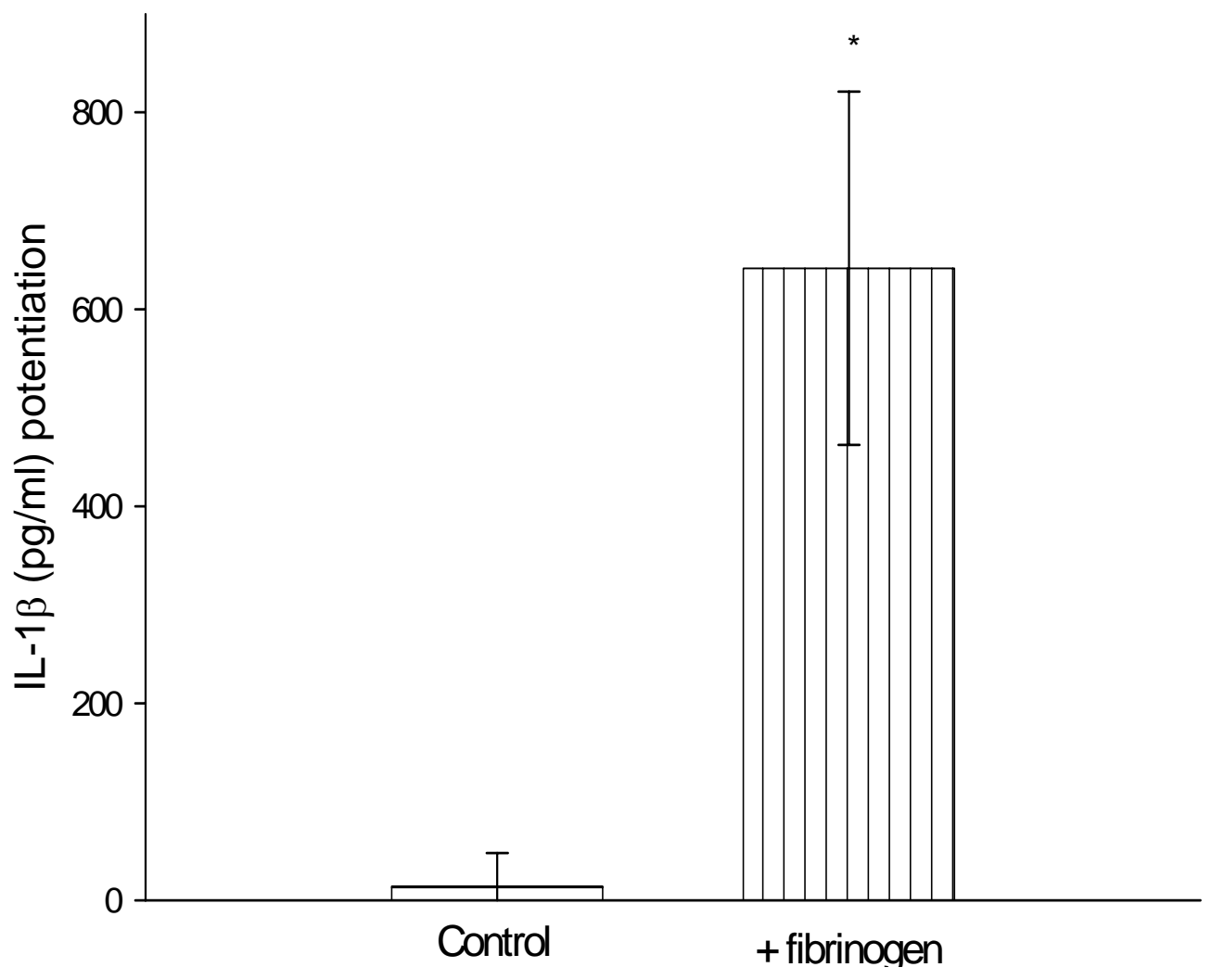


Figure 40: IL-6 release in mixed AM/TII co-culture, transwell AM/TII co-culture, or AM and TII monocultures. AM and TII cell concentration used in all cases was 0 . $25 \times 10^{6}$ cells $/ \mathrm{ml}$; exposure time was 18 hours. Values are means \pm SE of 4 experiments. $*$ indicates a significant difference $(\mathrm{p}<0.05)$ between AM/TII transwell co-culture and the sum of the separate cultures(AM+TII). + indicates a significant difference $(p<0.05)$ between mixed and transwell co-cultures.

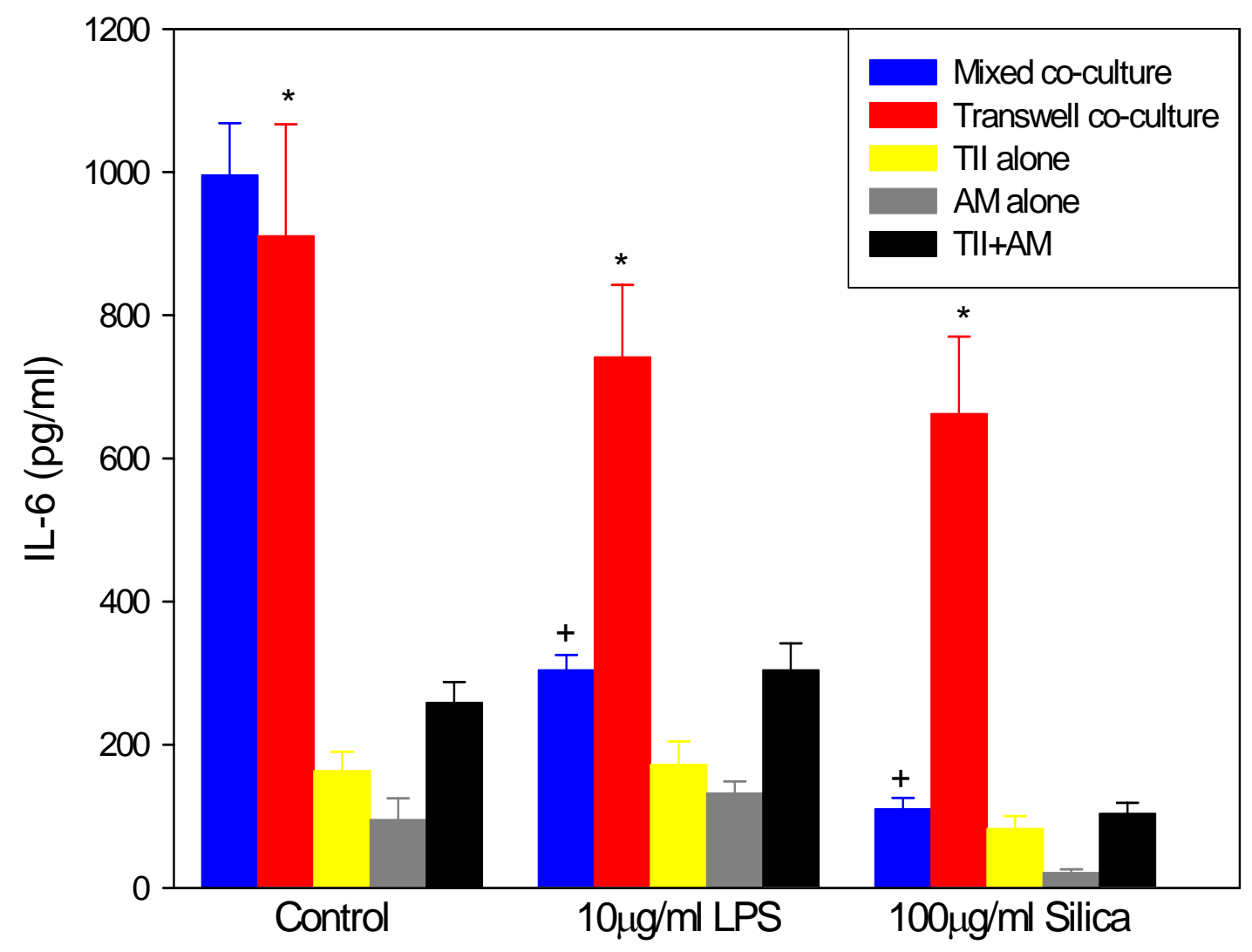


Figure 41: IL-6 potentiation (value in the mixed co-culture system minus value of the sum of the separate cell cultures) upon adding $0.8 \mathrm{mg} / \mathrm{ml}$ fibrinogen (a surfactant inhibitor) to AM/TII basal mixed co-culture versus IL-6 potentiation without adding fibrinogen (control). AM and TII cell concentration used in all cases was $0.25 \times 10^{6}$ cells $/ \mathrm{ml}$, exposure time was 18 hours. Values are means $\pm \mathrm{SE}$ of 4 experiments.

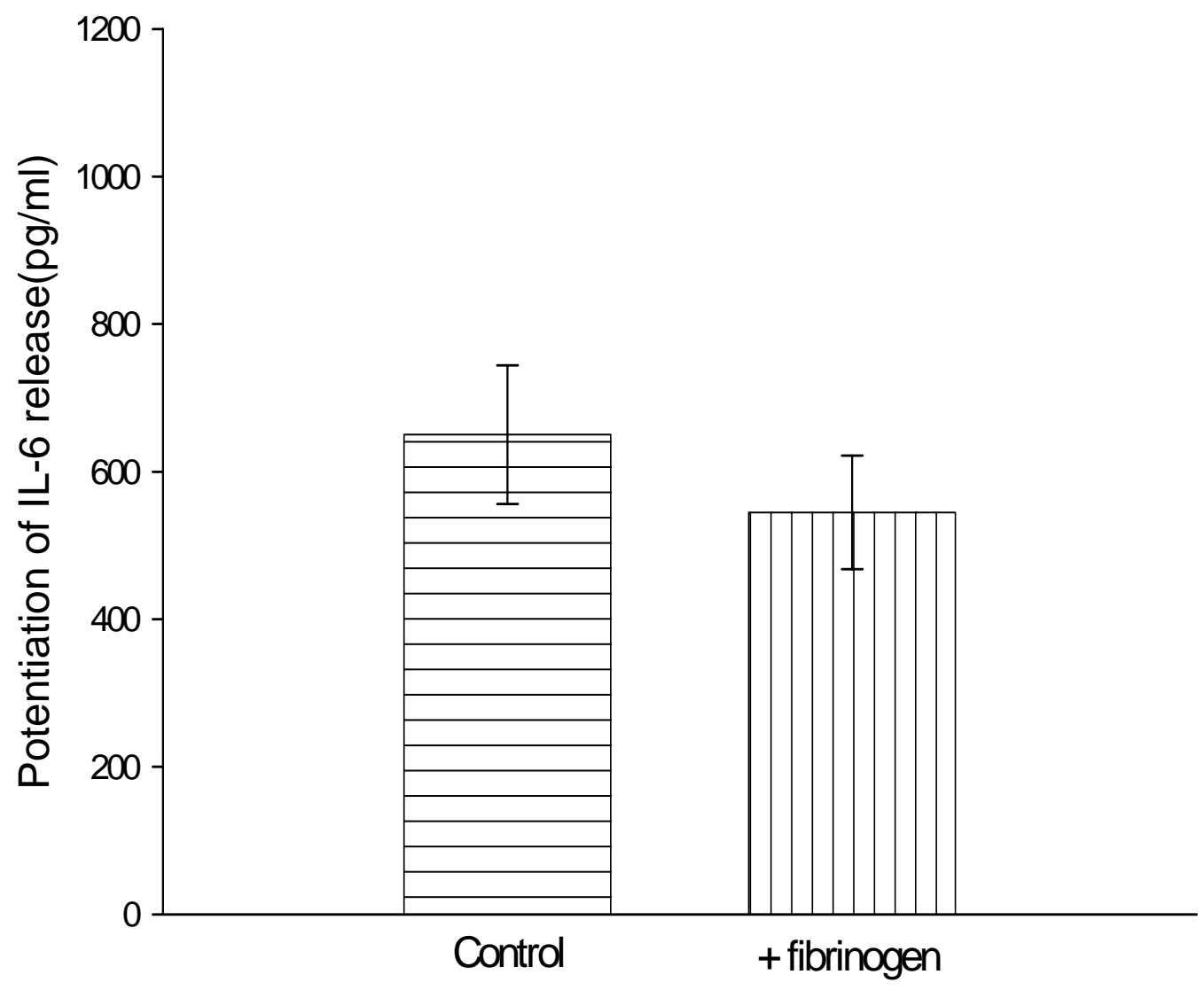


Figure 42: TNF- $\alpha$ and MIP-2 levels from AM's cultured on the transwell insert (or filter) relative to AM's cultured on the plate surface. AM concentration used in all cases was $0.25 \times 10^{6}$ cells $/ \mathrm{ml}$; exposure time was 18 hours. Values are means $\pm \mathrm{SE}$ of 3 experiments.

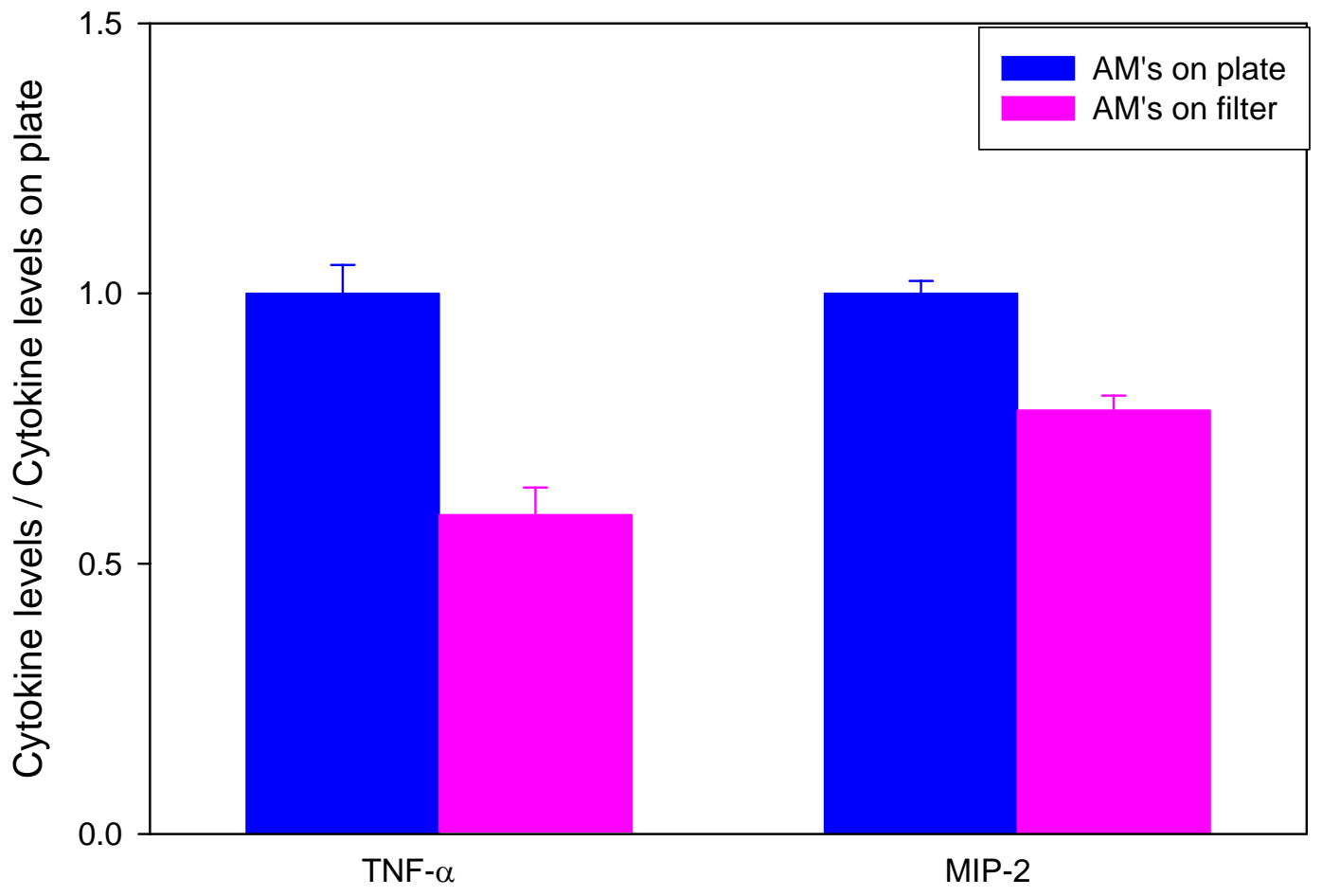


Figure 43 A: Diffusion of TNF- $\alpha$ through the transwell. ( $5 \mathrm{ng} / \mathrm{ml})$ TNF- $\alpha$ was added to the bottom transwell compartment (plate bottom), and 18 hours later, TNF- $\alpha$ was measured in both the bottom compartment and the insert. Values are means \pm SE of 3 experiments.

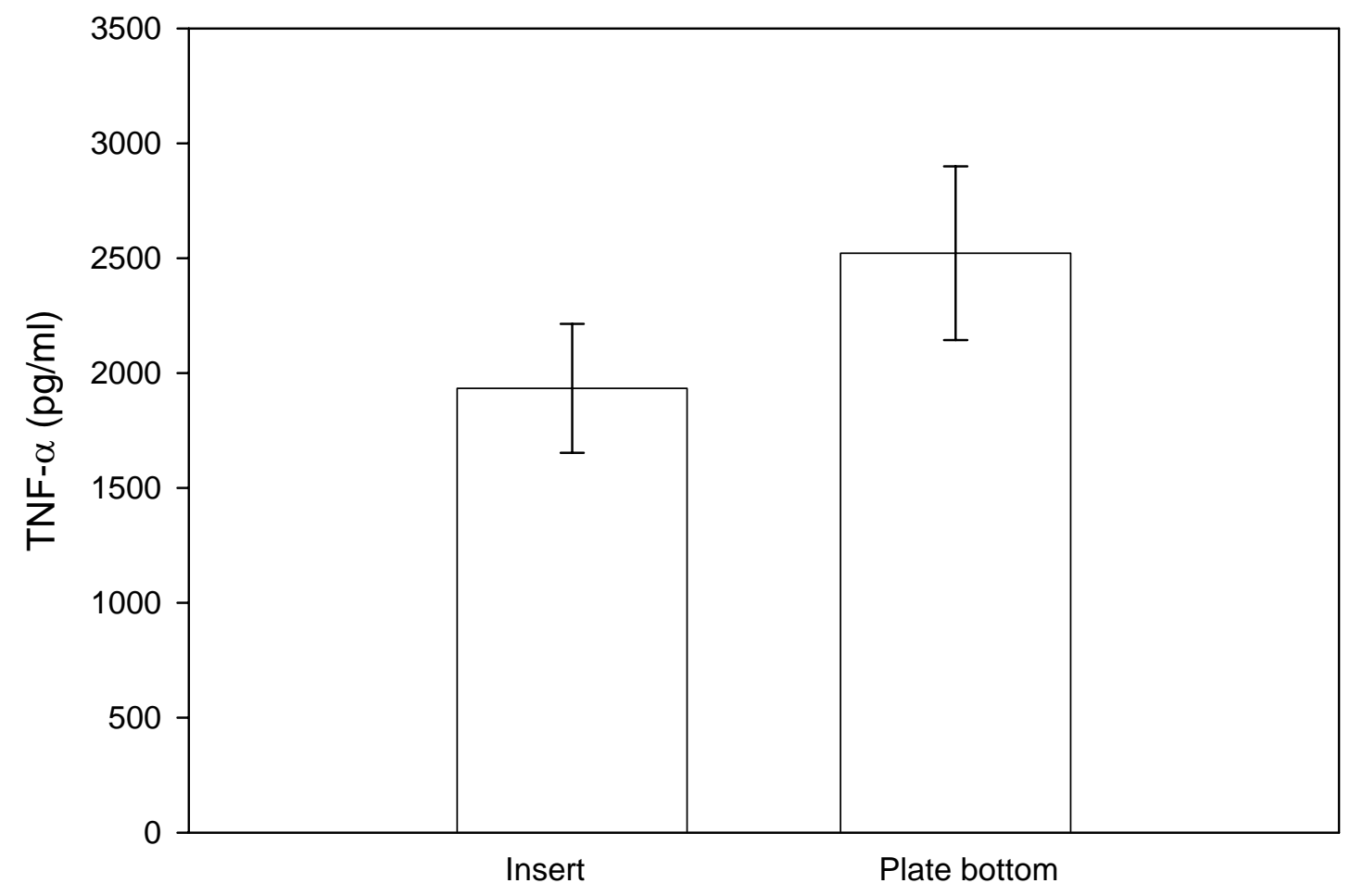


Figure 43 B: Diffusion of Survanta through the transwell. $2 \mathrm{mg} / \mathrm{ml}$ Survanta was added to the bottom transwell compartment (plate bottom), and 18 hours later, Survanta phospholipid was measured in both the bottom compartment and the insert. Values are means \pm SE of 3 experiments. * indicates a significant difference $(\mathrm{p}<0.05)$ in phospholipid content between the transwell insert and the plate bottom.

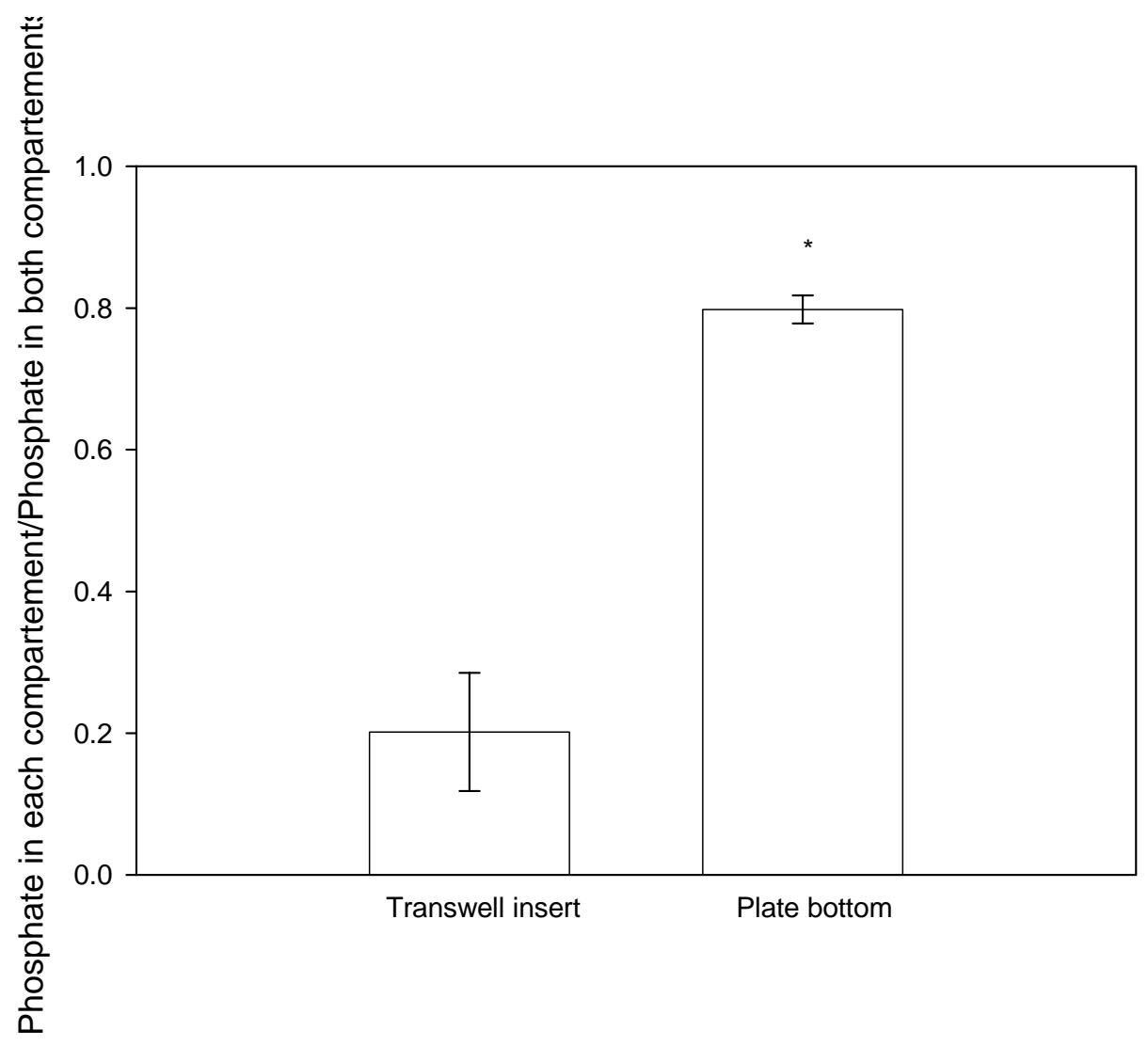


Figure 44: TNF- $\alpha$ and MIP-2 potentiation (value in the mixed co-culture system minus value of the sum of the separate cell cultures) upon adding $0.8 \mathrm{mg} / \mathrm{ml}$ fibrinogen (a surfactant inhibitor) to RAW/TII mixed co-culture versus potentiation without adding fibrinogen (control). RAW and TII cell concentration used in all cases was $0.25 \times 10^{6}$ cells/ml; exposure time was 18 hours. Values are means \pm SE of 3 experiments.

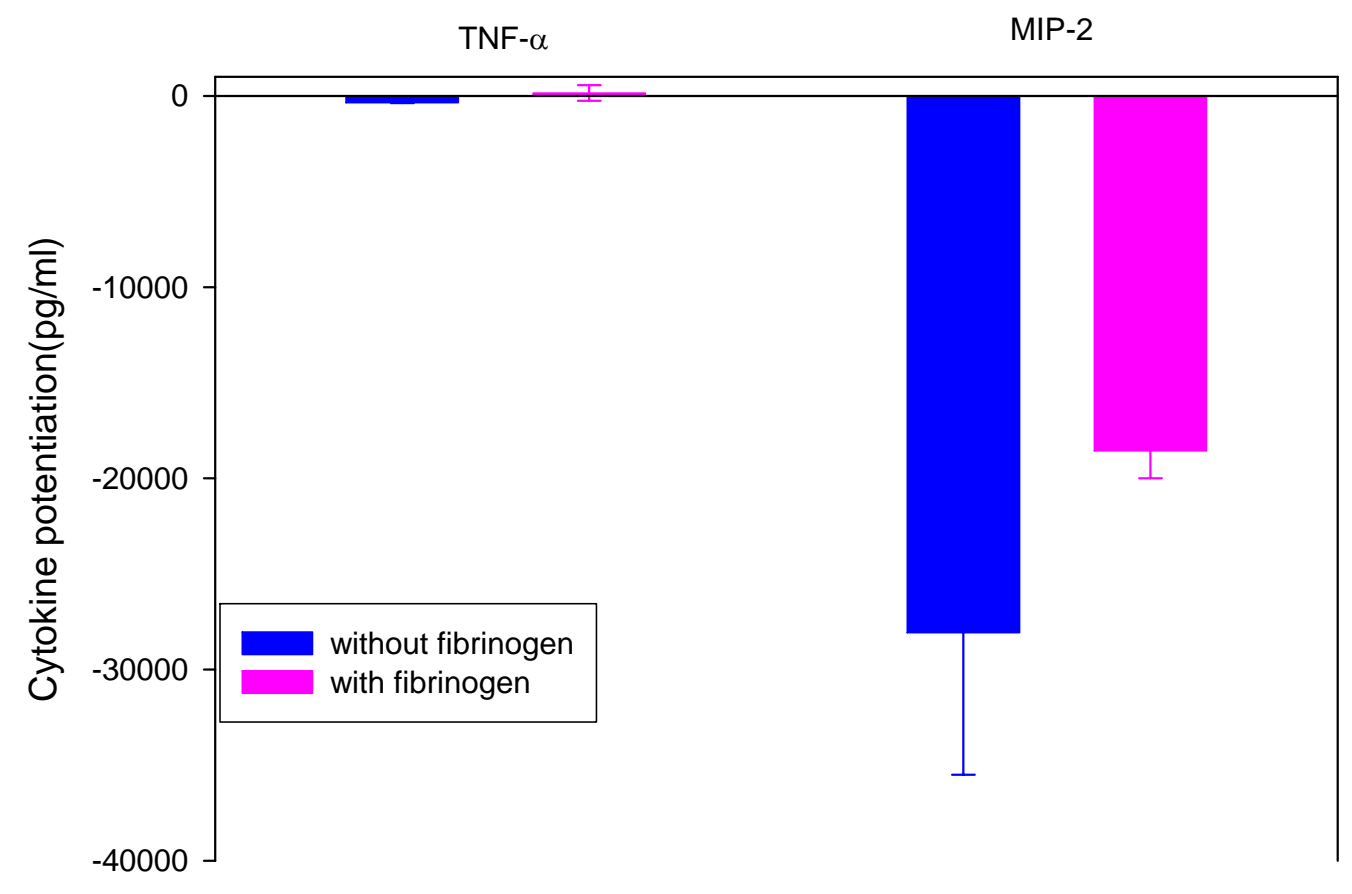


Figure 45 A: Fold difference (value in the transwell co-culture system divided by value of the sum of the separate cell cultures) in TNF- $\alpha$ release upon adding different inhibitors to AM/TII basal transwell co-culture versus fold difference without adding any inhibitor (control). AM and TII cell concentration used in all cases was $0.25 \times 10^{6}$ cells $/ \mathrm{ml}$; exposure time was 18 hours. * indicates a significant decrease $(p<0.05)$ in potentiation upon adding the inhibitor versus control. Values are means $\pm \mathrm{SE}$ of 5 experiments.

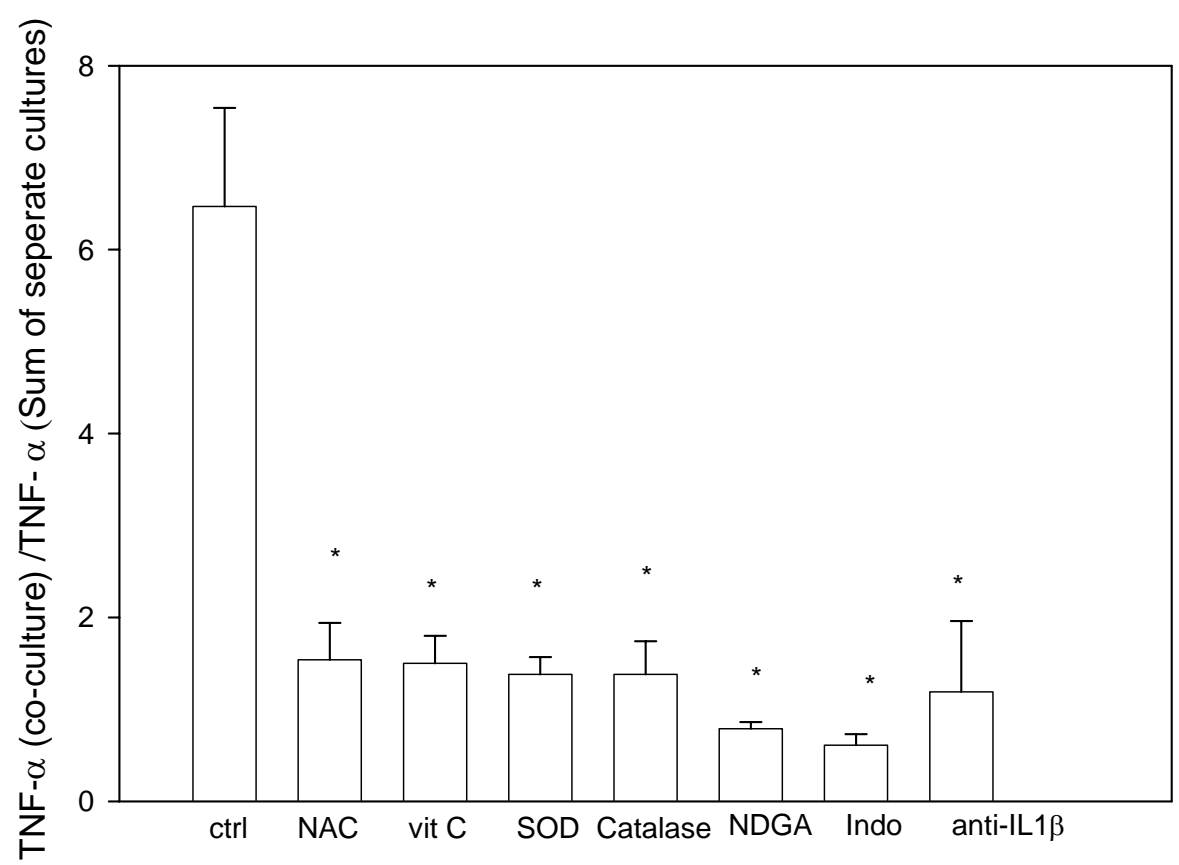

$\mathrm{N}$-acetyl cysteine (NAC): non-specific antioxidant $(1 \mathrm{mM})$

Vitamin C: non-specific antioxidant $(250 \mu \mathrm{M})$

Superoxide dismutase (SOD): superoxide inhibitor $(250 \mathrm{U} / \mathrm{ml})$

Catalase: hydrogen peroxide inhibitor $(5000 \mathrm{U} / \mathrm{ml})$

Nordihydroguaiaretic acid (NDGA): lipooxygenase inhibitor $(1 \mu \mathrm{M})$

Indomethacin: cyclooxygenase inhibitor $(1 \mu \mathrm{M})$

Anti-IL-1 $\beta$ : IL-1 $\beta$ neutralizing antibody $(0.2 \mu \mathrm{g} / \mathrm{ml})$ 
Figure 45 B: Fold difference (value in the transwell co-culture system divided by value of the sum of the separate cell cultures) in MIP-2 release upon adding different inhibitors to AM/TII basal transwell co-culture versus fold difference without adding any inhibitor (control). AM and TII cell concentration used in all cases was $0.25 \times 10^{6}$ cells $/ \mathrm{ml}$; exposure time was 18 hours. * indicates a significant decrease $(p<0.05)$ in potentiation upon adding the inhibitor versus control. Values are means \pm SE of 5 experiments.

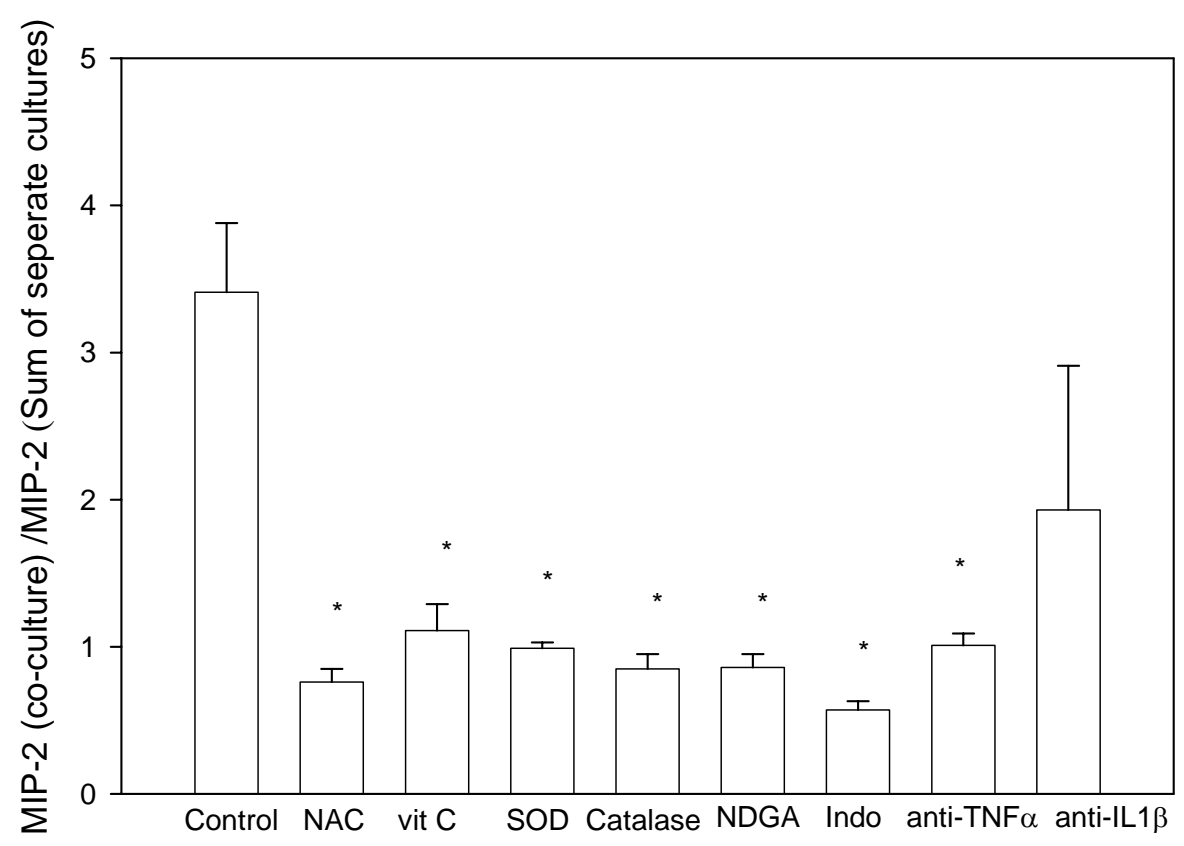

$\mathrm{N}$-acetyl cysteine (NAC): non-specific antioxidant $(1 \mathrm{mM})$

Vitamin C: non-specific antioxidant $(250 \mu \mathrm{M})$

Superoxide dismutase (SOD): superoxide inhibitor $(250 \mathrm{U} / \mathrm{ml})$

Catalase: hydrogen peroxide inhibitor $(5000 \mathrm{U} / \mathrm{ml})$

Nordihydroguaiaretic acid (NDGA): lipooxygenase inhibitor $(1 \mu \mathrm{M})$

Indomethacin: cyclooxygenase inhibitor $(1 \mu \mathrm{M})$

Anti-TNF- $\alpha$ : TNF- $\alpha$ neutralizing antibody $(0.5 \mu \mathrm{g} / \mathrm{ml})$

Anti-IL-1 $\beta$ : IL-1 $\beta$ neutralizing antibody $(0.2 \mu \mathrm{g} / \mathrm{ml})$ 
Figure 46 A: TNF- $\alpha$ levels relative to control upon adding different mediators to AM's. AM concentration used was $0.25 \times 10^{6}$ cells $/ \mathrm{ml}$; exposure time was 18 hours. Values are means \pm SE of 6 experiments.

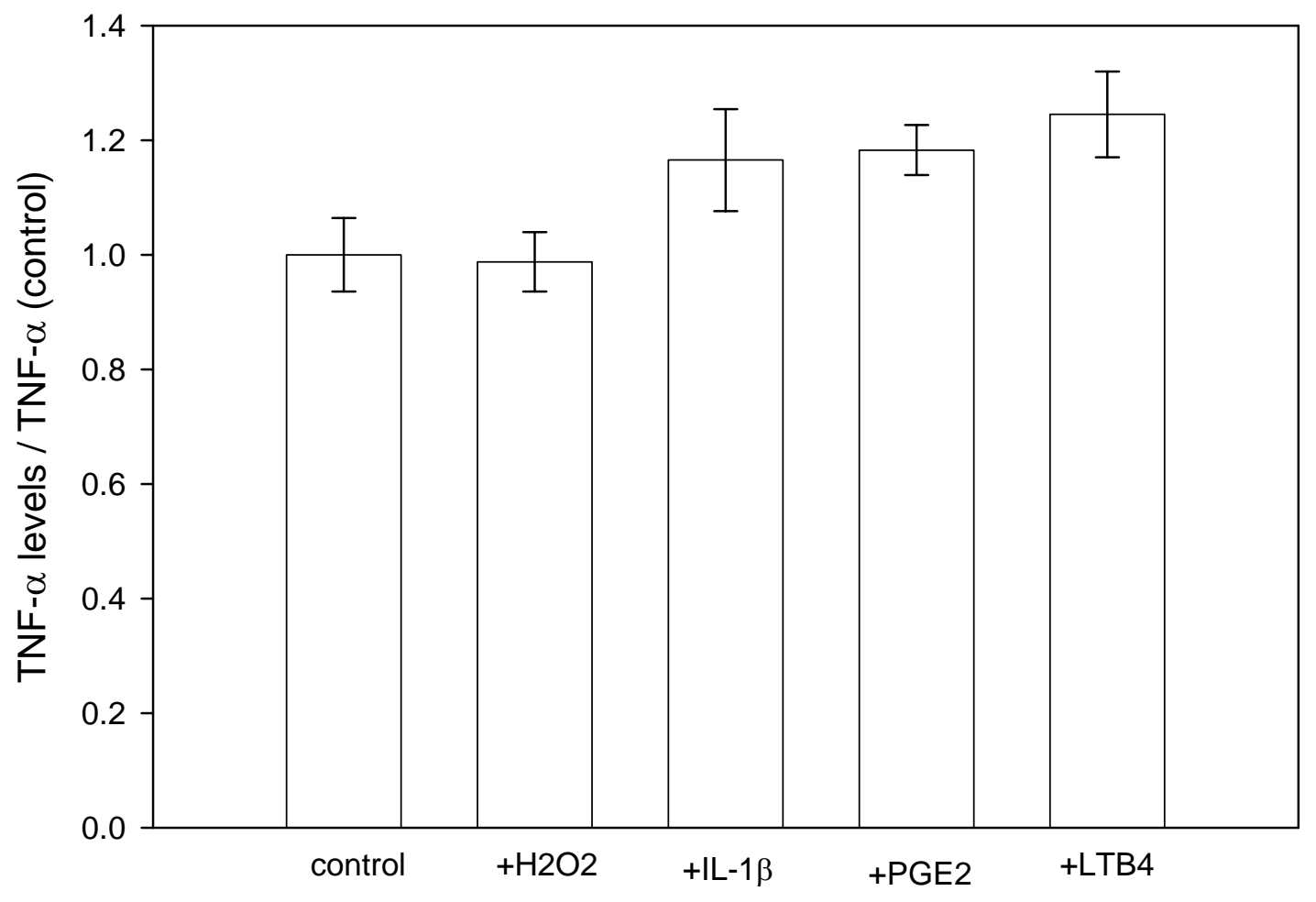

Hydrogen peroxide $\left(\mathrm{H}_{2} \mathrm{O}_{2}\right)(50 \mu \mathrm{M})$ : oxidation product IL-1 $\beta$ protein $(50 \mathrm{ng} / \mathrm{ml})$

Prostaglandin E2 (PGE2) (50 ng/ml): cyclooxygenase product Leukotriene B4 (LTB4) (50 ng/ml): lipooxygenase product 
Figure 46 B: MIP-2 levels relative to control upon adding different mediators to AM's. AM concentration used was $0.25 \times 10^{6}$ cells $/ \mathrm{ml}$; exposure time was 18 hours. * indicates a significant increase $(\mathrm{p}<0.05)$ in MIP-2 release upon adding the mediator versus control. Values are means $\pm \mathrm{SE}$ of 6 experiments.

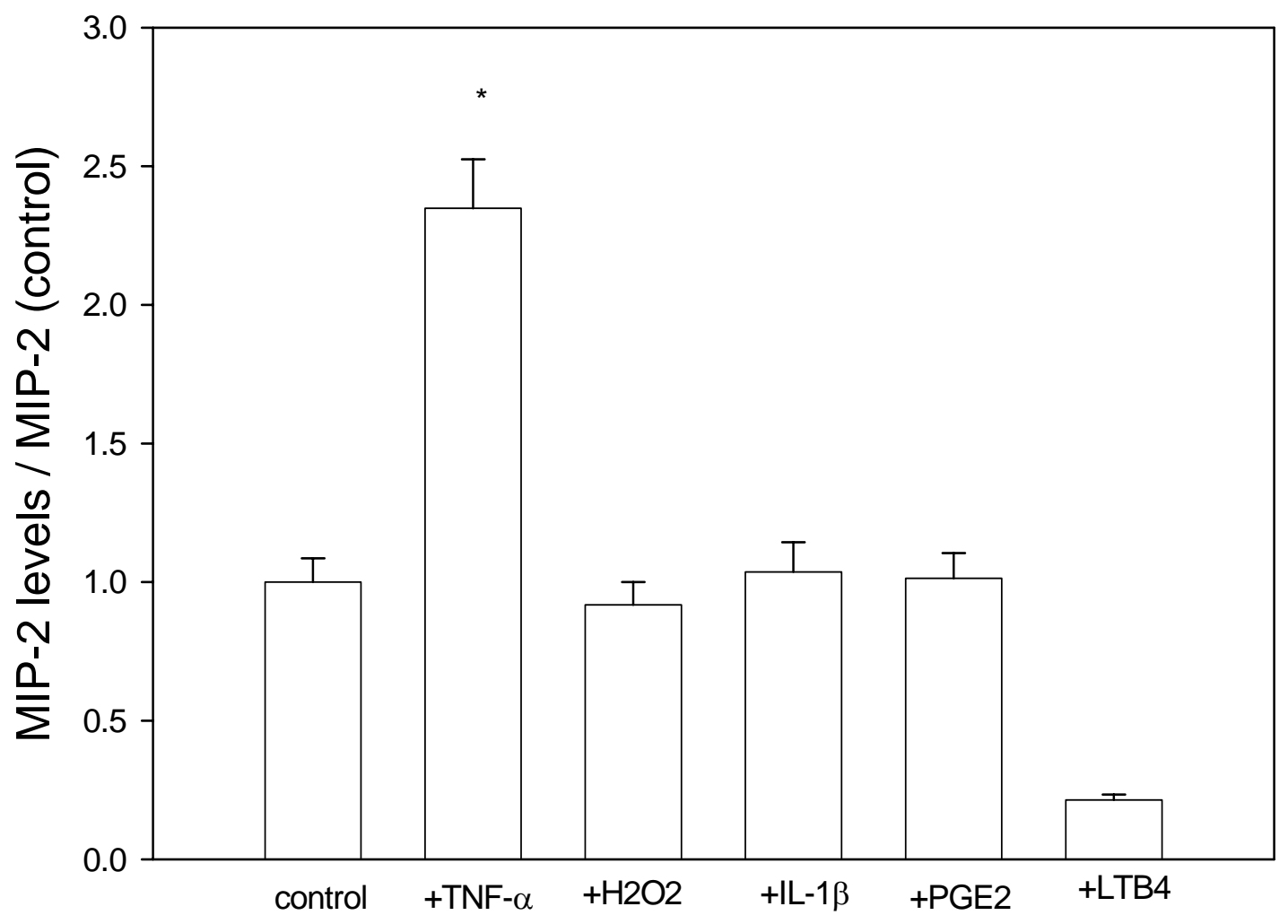

Hydrogen peroxide $\left(\mathrm{H}_{2} \mathrm{O}_{2}\right)(50 \mu \mathrm{M})$ : oxidation product TNF- $\alpha$ protein $(50 \mathrm{ng} / \mathrm{ml})$ IL-1 $\beta$ protein $(50 \mathrm{ng} / \mathrm{ml})$

Prostaglandin E2 (PGE2) $(50 \mathrm{ng} / \mathrm{ml})$ : cyclooxygenase product Leukotriene B4 (LTB4) $(50 \mathrm{ng} / \mathrm{ml})$ : lipooxygenase product 
Figure 47 A: TNF- $\alpha$ levels relative to control upon adding different mediators to TII cells. TII concentration used was $0.25 \times 10^{6}$ cells $/ \mathrm{ml}$; exposure time was 18 hours. Values are means \pm SE of 6 experiments.

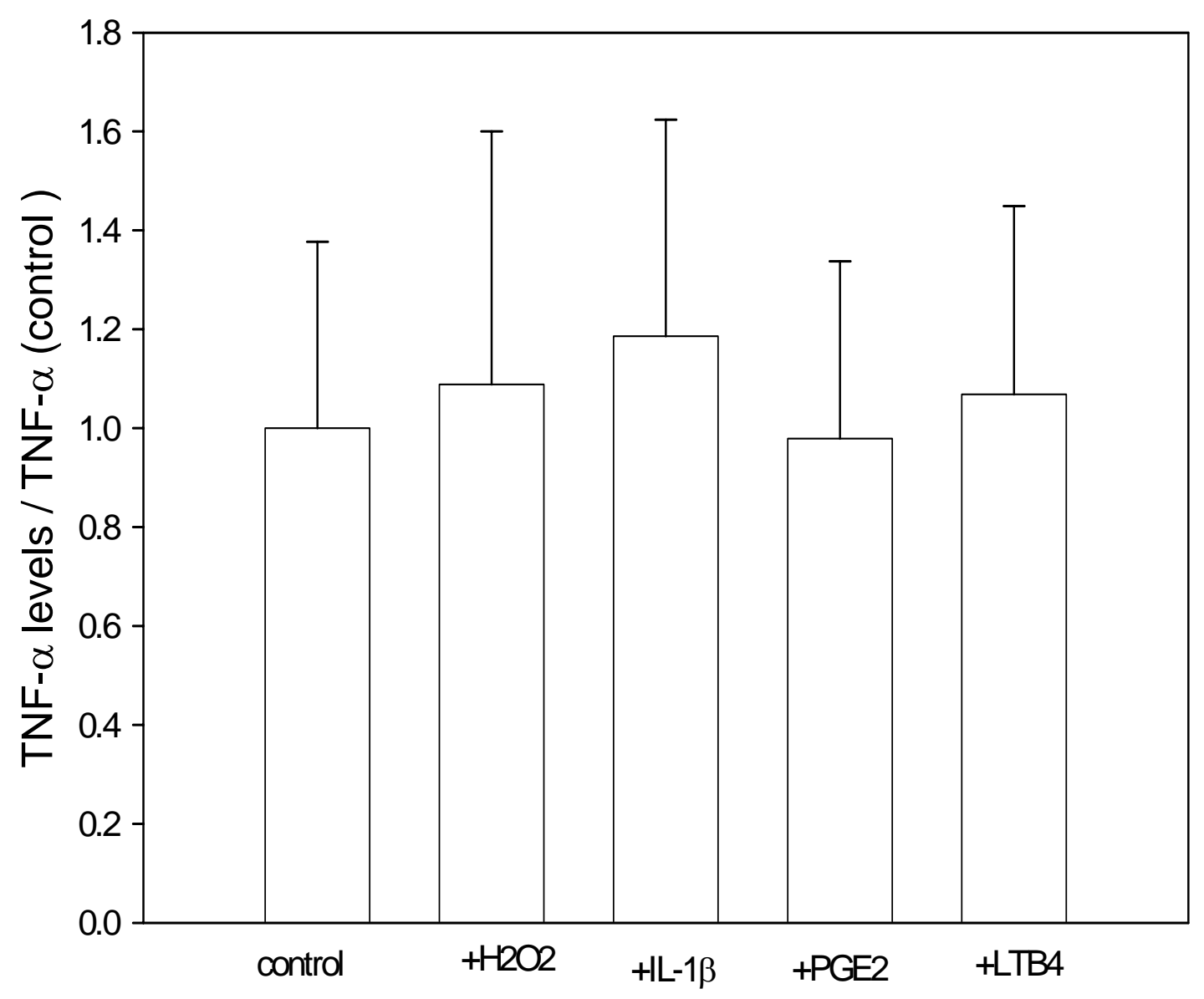

Hydrogen peroxide $\left(\mathrm{H}_{2} \mathrm{O}_{2}\right)(50 \mu \mathrm{M})$ : oxidation product IL-1 $\beta$ protein $(50 \mathrm{ng} / \mathrm{ml})$

Prostaglandin E2 (PGE2) $(50 \mathrm{ng} / \mathrm{ml})$ : cyclooxygenase product Leukotriene B4 (LTB4) $(50 \mathrm{ng} / \mathrm{ml})$ : lipooxygenase product 
Figure 47 B: MIP-2 levels relative to control upon adding different mediators to TII cells. TII concentration used was $0.25 \times 10^{6}$ cells $/ \mathrm{ml}$; exposure time was 18 hours. Values are means \pm SE of 6 experiments.

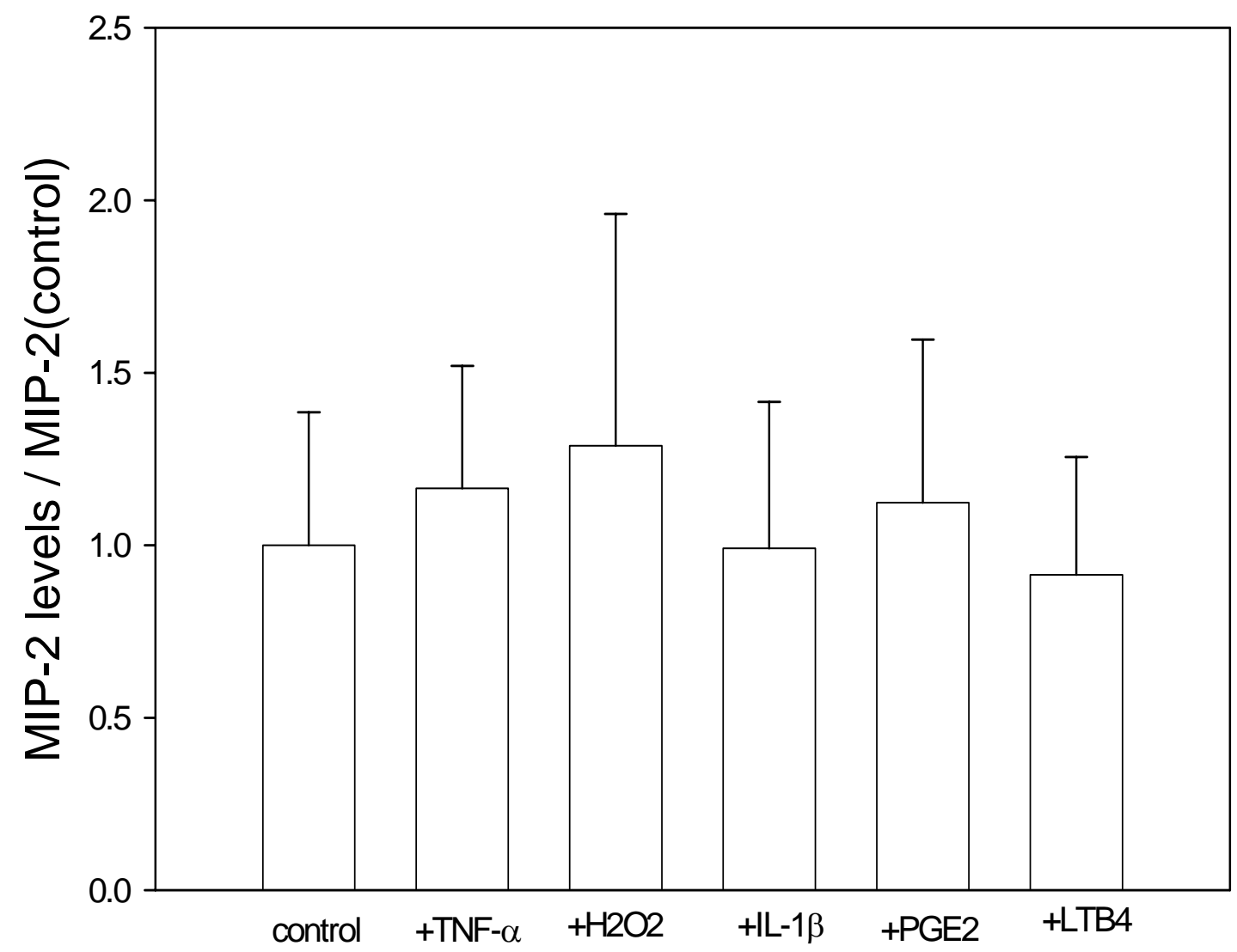

Hydrogen peroxide $\left(\mathrm{H}_{2} \mathrm{O}_{2}\right)(50 \mu \mathrm{M})$ : oxidation product TNF- $\alpha$ protein $(50 \mathrm{ng} / \mathrm{ml})$

IL-1 $\beta$ protein $(50 \mathrm{ng} / \mathrm{ml})$

Prostaglandin E2 (PGE2) (50 ng/ml): cyclooxygenase product Leukotriene B4 (LTB4) (50 ng/ml): lipooxygenase product 
Figure 48 : MIP-2 levels relative to control upon adding different mediator combinations to AM's. AM concentration used was $0.25 \times 10^{6}$ cells $/ \mathrm{ml}$; exposure time was 18 hours. * indicates a significant increase $(\mathrm{p}<0.05)$ in MIP-2 release upon adding the mediator(s) versus control. Values are means $\pm \mathrm{SE}$ of 6 experiments.

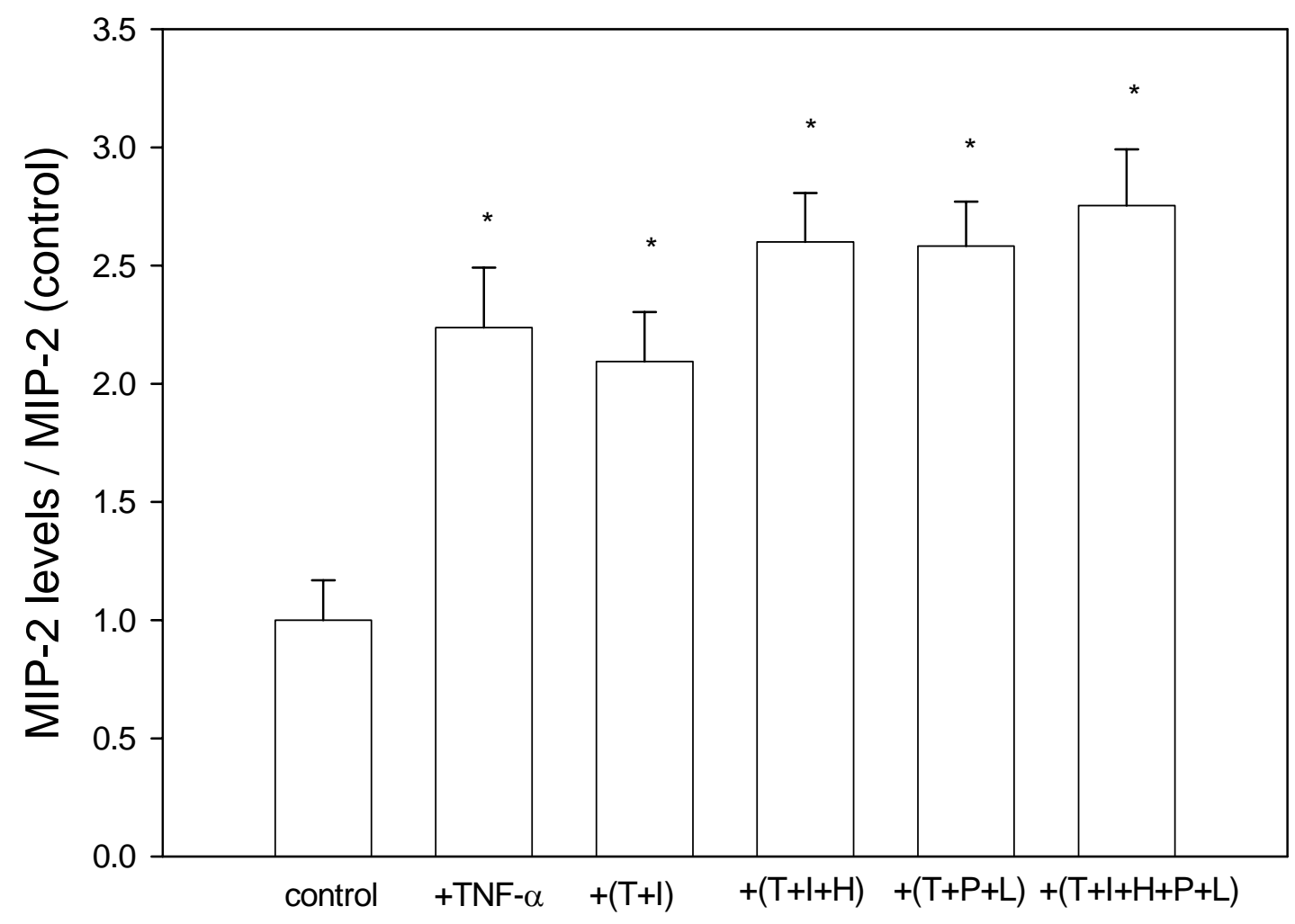

(H): Hydrogen peroxide $(50 \mu \mathrm{M})$ : oxidation product

(TNF-a or T): TNF- $\alpha$ protein $(50 \mathrm{ng} / \mathrm{ml})$

(I): IL-1 $\beta$ protein $(50 \mathrm{ng} / \mathrm{ml})$

(P): Prostaglandin E2 (50 ng/ml): cyclooxygenase product

(L): Leukotriene B4 (50 ng/ml): lipooxygenase product 
Figure 49: TNF- $\alpha$ and MIP-2 from AM's cultured in normal medium (control) and from AM's cultured in an 18-hour TII-conditioned medium. AM and TII concentration used was $0.25 \times 10^{6}$ cells $/ \mathrm{ml}$; exposure time was 18 hours. Values are means $\pm \mathrm{SE}$ of 3 experiments.

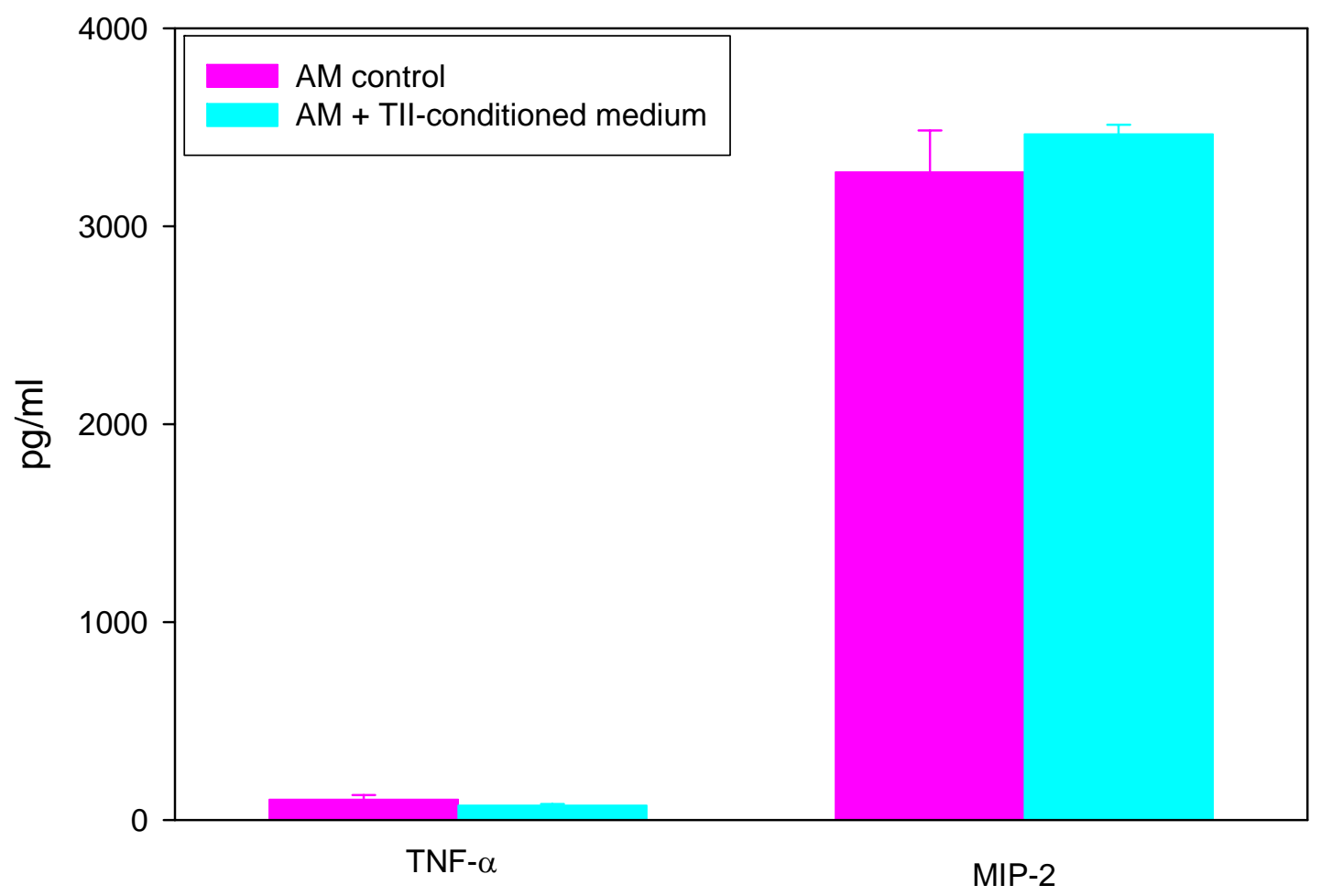


Figure 50: TNF- $\alpha$ and MIP-2 from TII cells cultured in normal medium (control) and from TII cells cultured in an 18-hour AM-conditioned medium. TII and AM concentration used was $0.25 \times 10^{6}$ cells $/ \mathrm{ml}$; exposure time was 18 hours. * indicates a significant $(\mathrm{p}<0.05)$ increase compared to control. Values are means $\pm \mathrm{SE}$ of 3 experiments.

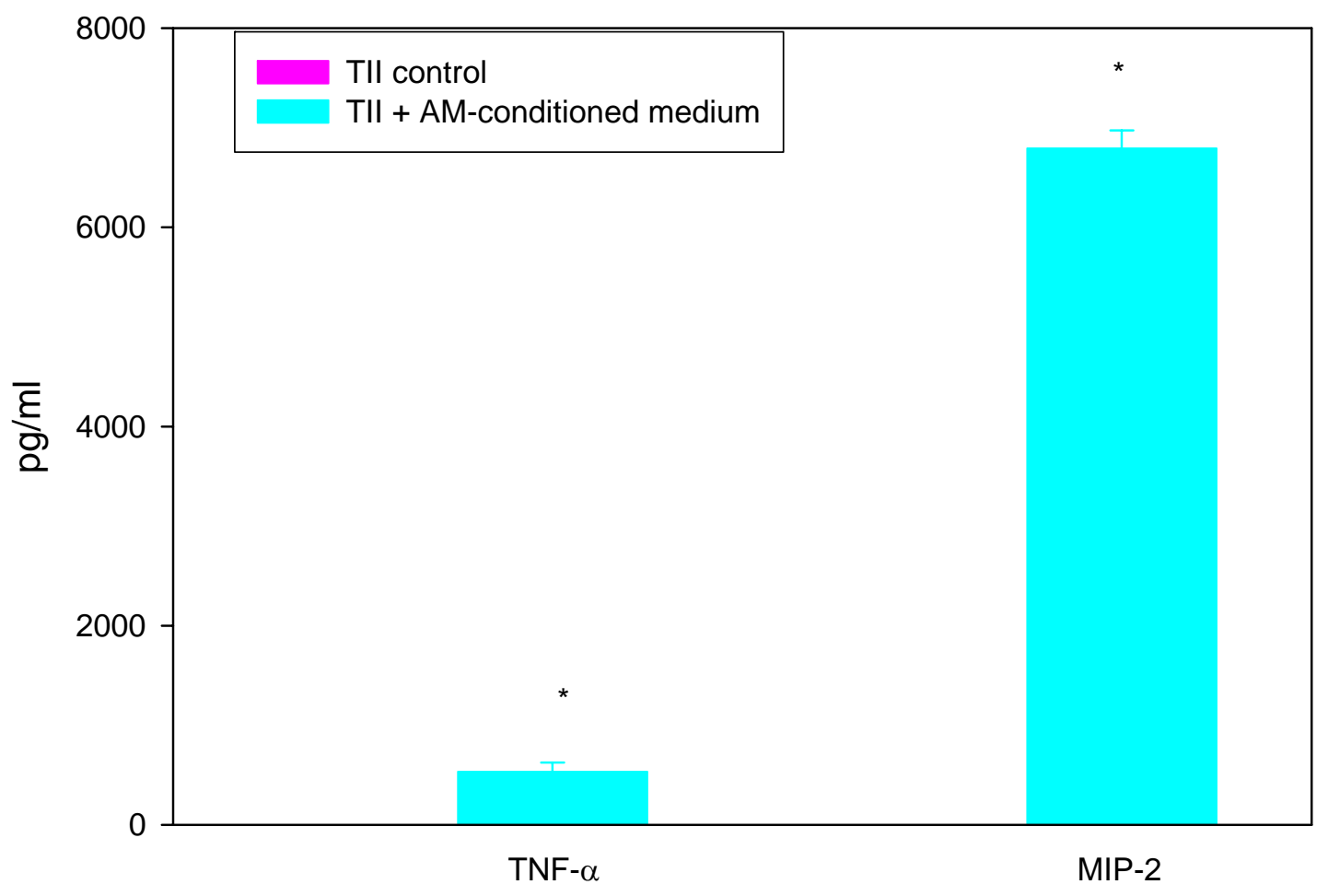


Figure 51 A: MIP-2 from TII cells cultured in normal medium (control) and from TII cells cultured in an 18-hour AM-conditioned medium, and in an 18-hour AM-conditioned medium plus anti-TNF- $\alpha$. TII and AM concentration used was $0.25 \times 10^{6}$ cells $/ \mathrm{ml}$; exposure time was 18 hours. $*$ indicates a significant $(p<0.05)$ increase compared to control. Values are means $\pm \mathrm{SE}$ of 3 experiments.

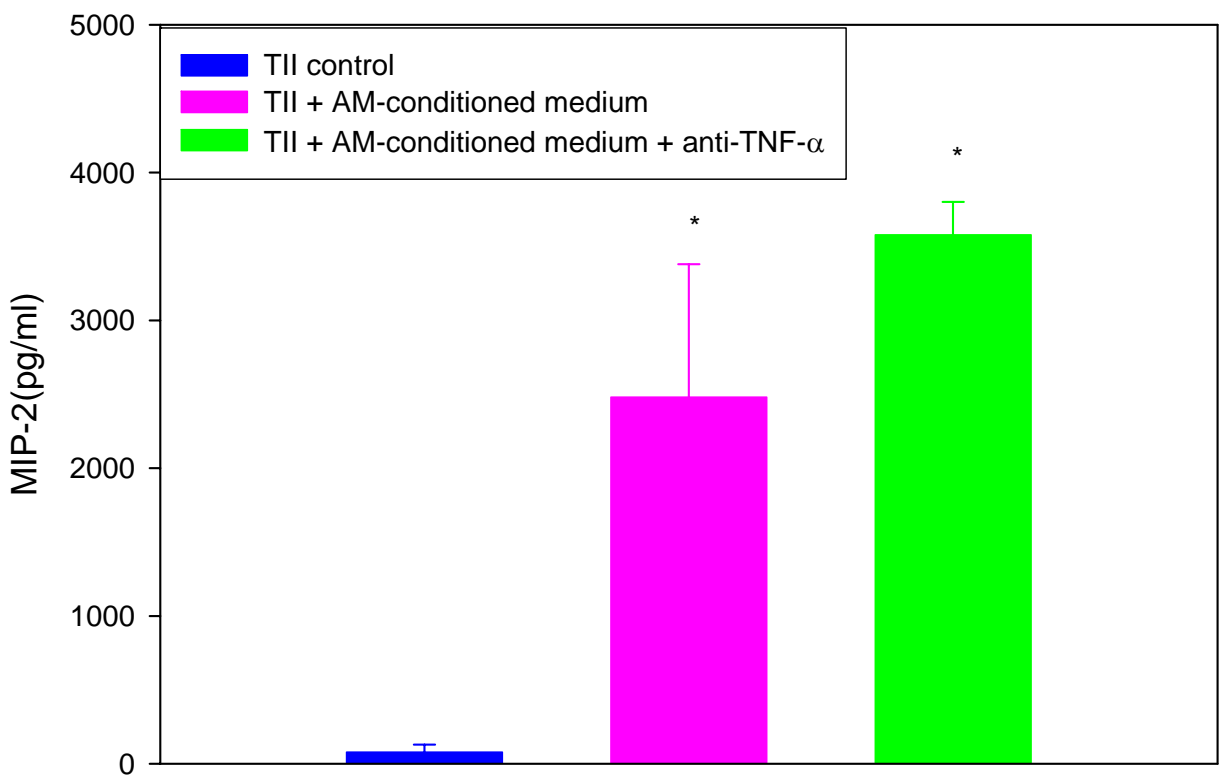


Figure 51 B: TNF- $\alpha$ and MIP-2 from TII cells cultured in normal medium (control) and from TII cells cultured in an 18-hour AM-conditioned medium, and in an 18-hour AMconditioned medium plus anti-IL-1 $\beta$. TII and AM concentration used was $0.25 \times 10^{6}$ cells $/ \mathrm{ml}$; exposure time was 18 hours. * indicates a significant $(\mathrm{p}<0.05)$ increase compared to control. Values are means $\pm \mathrm{SE}$ of 3 experiments.

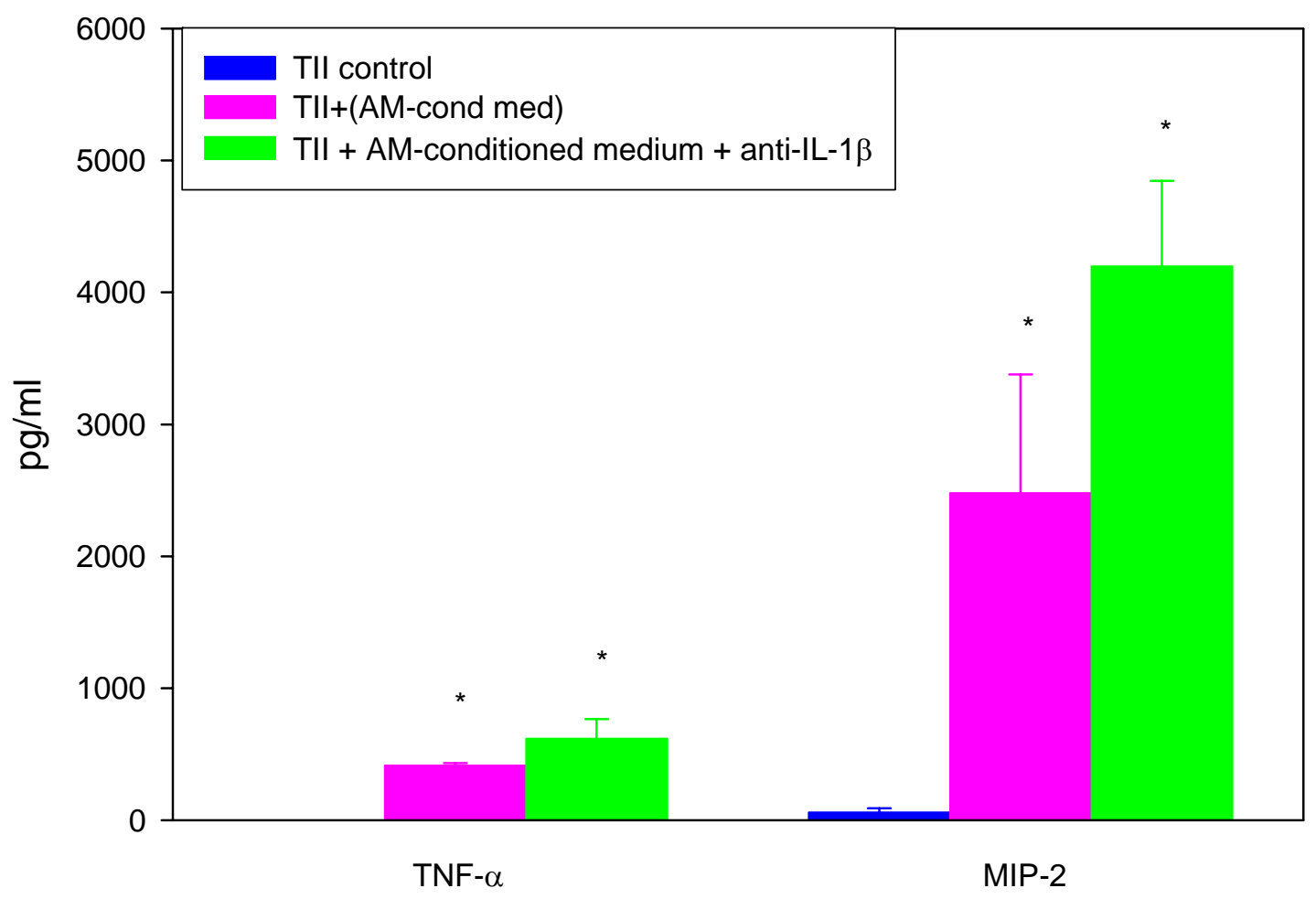




\section{$\underline{\text { Discussion }}$}

AM's are the alveolar derivatives of blood monocytes and are the first line of defense against outside contaminants and invaders (Lohmann-Matthes et al., 1994).

Phagocytizing AM's can produce reactive oxygen species through a respiratory or oxidative burst that directly contributes to killing microorganisms (Johnson, 1978). When incapable of killing foreign organisms by themselves, AM's recruit more phagocytic cells to the area by releasing chemokines, such as macrophage-inflammatory protein-2 (MIP-2), which acts to attract polymorphonuclear leukocytes (PMN's), monocytes and other cells from the pulmonary capillaries to the alveolar airspaces (Nielson et al., 1995). TII cells constitute approximately $60 \%$ of the alveolar epithelial cell population in number (Crapo et al., 1983). They are known to synthesize, store and secrete the surfactant material lining the alveoli. They can also produce NO" ROS and cytokines in response to different stimuli (Punjabi et al., 1994). RLE-6TN cells were derived from rat alveolar TII cells by Driscoll et al. (1995a). Like primary TII cells, RLE-6TN cells contain lamellar bodies for surfactant storage, and they have the ability to produce cytokines, NO and other ROS when stimulated (Stringer and Kobzik, 1998; Driscoll et al., 2001).

As discussed earlier, evidence suggests that hyperproduction of reactive oxidants and inflammatory mediators plays a role in adverse pulmonary responses to silica or LPS. It is also clear that AM's and TII cells are involved in the production of these reactive and inflammatory products. However, no data were found that compared the release of several inflammatory mediators from AM's and TII cells under the same culture conditions, same exposures, and same cell concentrations. Also, no literature was found 
that compared the responsiveness of RLE-6TN, a type II cell line, to primary TII cells under the same culture conditions and following exposure to LPS and silica. In addition, although AM/TII cell interactions have been suggested to be very important in cellular responses, this interaction has not been studied in parallel under different interaction conditions (transwell and mixed co-culture) or different exposure conditions (basally, upon LPS exposure, or following silica exposure). And finally, there haven't been any studies that attempted different approaches to try to find specific mediators important in $\mathrm{AM} / \mathrm{TII}$ intercellular communication.

Main objective of this study: Contribute to advancing the understanding of the role of AM's and TII cells in the induction of pulmonary inflammation and injury in response to silica and LPS, and improve our understanding of the interaction between AM's and TII cells which would occur in vivo.

Aim 1: Determine the relative responsiveness of AM's, primary TII cells and RLE-6TN, a TII cell line to silica and LPS under comparable conditions. This part of the study was an attempt to answer the following unresolved questions: 1) What is the relative contribution of AM's and TII cells to the production of oxidants, chemokines, and cytokines in the lungs following LPS or silica exposure? The answer to this question could help in revealing which cell type contributes more inflammatory mediators following lung injury caused by LPS or silica. It could also help reveal which agent is more potent at stimulating the release of inflammatory mediators and hence inducing more severe lung injury. 2) Is the responsiveness of cell lines and primary cells similar? The answer to this question could determine if RLE-6TN cell line could be used in 
research in place of primary TII cells, since TII isolation technique is more time and money consuming.

Main results and discussion for aim 1:

1A-Responsiveness of cell types to stimuli:

AM> TII: (True for NO ,TNF- $\alpha$, MIP-2, and IL-1 $\beta$, but not true for IL-6 and ROS):

The results of the present study show that primary AM's were significantly more active in producing NO" TNF- $\alpha$, MIP-2, IL-1 $\beta$, and ROS than primary TII cells, which in turn were more active than RLE-6TN cells upon LPS exposure. Upon silica exposure, primary AM's are significantly more active in producing TNF- $\alpha$, MIP-2, and IL-1 $\beta$ than primary TII cells, which in turn are more active than RLE-6TN cells. In contrast, primary AM's and primary TII cells released equivalent amounts of IL-6, and ROS upon exposure to silica.

AM's, being professional phagocytes, can clear inhaled microbes and particles from the lungs. Therefore, it's expected that AM's would secrete high levels of inflammatory cytokines and reactive products which can cause lung damage and inflammation both of which might play a critical role in occupational lung diseases. The data in the present study support the major contribution of AM's in lung inflammation and disease upon occupational exposure, but it also raises another lung cell type to a higher importance level as far as its contribution to pulmonary disease. Indeed, data from our results suggest that, although AM's are more active than TII cells in producing many inflammatory mediators upon LPS and silica exposure, TII cells are also capable of producing highly significant levels of inflammatory mediators. Indeed, our data support recent evidence suggesting that alveolar type II epithelial cells (TII) may significantly 
contribute to lung inflammation by a direct interaction with a stimulant (Blau et al., 1994; Crippen et al., 1995; Finkelstein et al., 1997). Our data also extend previous literature by measuring mediator release from primary TII cell cultures instead of TII-like cell lines used in most previous studies.

Among the very few studies comparing AM's and TII cells in separate primary cultures are those from Crestani et al. (1994), which support our findings that TII cells produce more IL-6 than AM's basally in vitro. Also, it's not surprising to see that TII cells could produce comparable amounts of ROS as AM's upon silica exposure. Indeed, $\mathrm{TII}_{2}$ consumption measured basally in the present study in preliminary studies characterizing the viability of TII cells was approximately $193 \pm 82 \mathrm{nmoles} / 10^{6} \mathrm{cell} / \mathrm{s} / \mathrm{hr}$, and this value is comparable to values reported in the literature (Jones et al., 1982), and is significantly greater than AM oxygen consumption $\left(\sim 46.2 \mathrm{nmoles} / 10^{6}\right.$ cells $\left./ \mathrm{hr}\right)$ as reported by Castranova et al. (1980). TII cells are more dependent on mitochondrial respiration, whereas AM's are more dependent on glycolysis (Fisher et al., 1980). This is manifested basally and upon exposure. Indeed, Chandel et al., (2000), reported that, while LPS activates NF- $\mathrm{kB}$ in the murine macrophage cell line J 774. 1 through the release of significant levels of ROS, mitochondrial ROS are not required for LPS activation of NF$\kappa B$ in J 774. 1. Previous data from Driscoll et al., (2001), have reported a significant increase in mitochondrial-derived $\mathrm{H}_{2} \mathrm{O}_{2}$ in RLE-6TN cells following silica exposure. Our data complement previous literature by having measured this ROS increase in primary TII cells. TII have a higher intracellular taurine concentration, and a comparable ascorbate intracellular concentration than AM's (Banks et al., 1989; Castranova et al., 
1983). Since TII cells contain more antioxidants than AM's, they might have the ability to produce more oxidants while resisting oxidant injury.

TII>RLE-6TN (True for NO , TNF- $\alpha$, MIP-2, IL-1 $\beta$, and ROS ; but not true for IL-6): When it was established, RLE-6TN cell line had promise to be a potential alternative to the costy and time consuming TII cell isolation in studies involving pulmonary epithelial cells (Driscoll et al., 1995a). Indeed, since then, the RLE-6TN cell line has been used in place of primary TII cells in many experiments studying the pulmonary epithelium without questioning its sensitivity or its level of responsiveness compared to primary TII cells. For this reason, the present study had, among other aims, the goal to compare primary rat TII cells to RLE-6TN cells, a rat TII cell line. For this purpose, the same mediators released from the two cell types were measured under comparable conditions. Primary TII cells were significantly more active in producing NO , TNF- $\alpha$, MIP-2, IL$1 \beta$, and ROS than RLE-6TN cells upon LPS exposure. Upon silica exposure, primary TII cells were significantly more active in producing TNF- $\alpha$, MIP-2, IL-1 $\beta$, and ROS than RLE-6TN cells. In addition, primary TII cells showed a higher sensitivity to LPS and silica than RLE-6TN. Indeed, a much higher LPS or silica dose is required to initiate significant mediator release from RLE-6TN cells. For some mediators, namely TNF- $\alpha$ and IL-1 $\beta$, even very high stimulant doses, which caused some cell injury, were incapable of inducing significant release from RLE-6TN cells. This lower responsiveness and sensitivity of the TII cell line to stimuli was obvious in data by Driscoll et al. (1996a) where it's clear to see that induction of MIP-2 mRNA from primary TII cells was more than MIP-2 mRNA from RLE following exposure to the same 
silica dose. Primary TII cells also responded at a lower silica dose and were thus more sensitive than the cell line.

Some studies have reported similar responsiveness of primary TII and RLE-6TN cells to certain stimuli. In fact, whereas our study reports a several fold lower sensitivity and responsiveness for MIP-2 release from RLE-6TN compared to primary TII cells upon LPS exposure, Driscoll et al. (1996a) showed that MIP-2 mRNA measured in both cell types was similar following LPS exposure. After looking at Driscoll's study experimental procedures, it was noticed that this group's TII cell isolation technique involved culturing the cells for 3 days after isolation prior to exposure. Reports indicate that morphological and biochemical changes in primary TII cells are more probable with time in culture (Dobbs et al., 1986). This could explain the reason for the lower responsiveness of primary TII cells in Driscoll's study. Other studies reporting lower primary TII cell responsiveness include one by Punjabi et al. (1994) where no significant induction of NO production was detected in primary TII cells in response to $1 \mu \mathrm{g} / \mathrm{ml}$ LPS. Comparing the experimental conditions of the study by Punjabi and colleagues to the study in our hands, one main difference could be observed. Indeed, we used $10^{6}$ cells/well which is over three times more cells per well than Punjabi and colleagues' study that only used $3 \times 10^{5}$ cells/well. It might be possible that $\mathrm{NO}$ production from the lower cell number could not be detected by the Greiss reaction technique.

Although using the RLE-6TN cell line would have been a less costly and time consuming method to study pulmonary epithelial TII cells, our results suggest that using this cell line would not reflect, or even be close to responses of primary TII cells. Hence, RLE-6TN 
cells may not be a good substitute for primary TII cells in separate culture or in co-culture with other cell types.

1B-Potency of stimuli: As mentioned earlier, silica and LPS are two main airborne contaminants of major importance to lung pathology. Silica, being highly fibrogenic and biologically toxic, can directly cause cellular toxicity. It can also initiate an inflammatory response that could include increased oxidant production and proinflammatory mediator secretion as a result of nuclear transcription factor- $\mathrm{kB}$ (NFкB) activation (Kang et al., 2000; Vallyathan and Shi, 1997) in target and recruited cells. Also, the cellular signaling cascade triggered by LPS binding to target cells is believed to induce the synthesis and release of many inflammatory mediators, such as the proinflammatory cytokines TNF- $\alpha$, IL- $\beta$, and IL-6, (Chen et al., 1995; Christman et al., 1998).

In the present study, LPS was found to be more potent than silica in inducing NO" TNF$\alpha$, MIP-2, and IL-6 release from the 3 cell types. In contrast, LPS and silica had a comparable ability to induce IL-1 $\beta$ production from the 3 cell types, whereas silica was more potent than LPS in inducing ROS production, especially from primary TII cells. LPS>silica. (True for NO , TNF- $\alpha$, MIP-2 and IL-6; not true for IL-1 $\beta$ or ROS): Although Chen et al. (1995) reported a stronger activation of one of the NF- $\mathrm{BB}$ forms (p50/p50 homodimer) in the early phase after stimulation of a macrophage cell line with silica than after stimulation with LPS, considerable literature supports the hypothesis that LPS is more potent than silica in inducing cytokine release from AM's. Blackford et al., (1994) have shown that iNOS mRNA and enzyme levels increase much more in AM's following in vivo exposure of rat to LPS ( 89 fold for the mRNA and 7 fold for the protein 
respectively) than following silica exposure (36 and 3 fold, respectively). Also, Dubois et al. (1989) reported that TNF and $\mathrm{LTB}_{4}$ release from primary AM's following in vitro LPS exposure was higher than the released from AM's following silica exposure. Much less data exist that compare LPS and silica exposure in primary TII or RLE-6TN cells. Some data from Driscoll et al. (1996a) suggest that MIP-2 mRNA from primary TII and RLE-6TN cells following in vitro LPS exposure might be higher than that produced following silica exposure. Our data clearly show that LPS is more potent than silica in inducing NO and MIP-2 from primary TII and RLE-6TN cells. Our data also show that LPS is more potent than silica in inducing TNF- $\alpha$ from primary TII cells. As for ROS, although silica and LPS have been both reported to induce ROS release in some TII cell lines and AM's (Barrett et al. (1999 a and b); Shi et al. (1999)), the relative potency of these two stimuli was not directly compared. Chen et al. (1998) reported that the antioxidant ascorbate decreased silica-induced, but not the LPS-induced, NF- $\kappa$ B activation in the macrophage cell line RAW 264. 7, suggesting that ROS production was greater after silica exposure than after LPS exposure. Also, Zeidler et al. (2003) has reported slightly lower $\mathrm{H}_{2} \mathrm{O}_{2}$ levels in murine AM's exposed in vitro to LPS than silica. As for the present study, while the results for AM's show that ROS released following in vitro silica exposure are comparable or slightly higher than ROS levels released following LPS exposure, results for primary TII cells show a much higher potency of silica compared to LPS in inducing ROS. Indeed, whereas LPS produced no detectable increase in oxidant release in primary TII cells, silica stimulated these cells to produce high levels of ROS, which exceeded those produced by AM's under the same exposure conditions. 
As mentioned earlier and, as expected, silica exposure did not result in a substantial release of NO from our three cell types. Indeed, Huffman et al. (1998) have shown that although in vivo exposure to silica can stimulate NO production from various cell types, it cannot do the same in vitro. Also, conditioned medium from BAL fluid (which includes mediators released from TII cells) following in vivo silica exposure was effective in making naïve AM's produce $\mathrm{NO}$ in response to silica exposure in vitro. The most probable explanation for the contrasting results between the in vivo and in vitro setting is the presence of multiple types of cells in the in vivo setting. Hence, different cells in the lung alveolar area, including AM's and TII cells or recruited PMN's, might interact with each other, thereby possibly modifying each other's responses. Many more studies contribute to the evidence of the importance of $\mathrm{AM} / \mathrm{TII}$ intercellular interactions. Those include a study by Miles et al. (1999) that has shown that surfactant released from TII cells inhibits LPS-induced NO production from AM's in vitro. Along the same lines, Rao et al. (2000) have reported that surfactant decreases LPS-induced TNF- $\alpha$ and IL-1 $\beta$ release from AM's in vitro. In contrast, Blau et al. (1994) have shown that SP-A, an important surfactant protein, increases the production of colony stimulating factor (CSF) from primary AM's in vitro. Also, Leslie et al. (1985) have reported that AM's stimulate DNA synthesis in TII cells in vitro, while Standiford et al. (1990) have shown that conditioned media from LPS-stimulated AM's increased IL-8 mRNA in A549, a human pulmonary TII-like epithelial cell line. One more study that stresses the importance of intercellular interactions in cellular responses is by Crestani et al. (1994) which showed that AM-conditioned media increases IL-6 production by TII in vitro under basal conditions. 
Aim 2: Determine if intercellular interactions exist and under what conditions they can be demonstrated. Does intercellular communication alter the activity of AM's and/or TII cells? The answer to this question could help in developing in vitro experiments to more closely mimic in vivo situations. In this part of the study, AM/TII intercellular communication was evaluated under two different co-culture settings: the cell types were separated by a transwell insert, or they were mixed in culture.

Main results and discussion for aim 2:

2A-Transwell co-culture: In the transwell setting of the present study, AM's probably do not go across the insert filter since its $0.4 \mu \mathrm{m}$ pore size is 5 times smaller than the $2 \mu \mathrm{m}$ Boyden chamber membrane pore size used to measure chemotaxis (Schagat et al., 2003). The most consistent change observed using this experimental system was considerable potentiation under basal conditions, i. e., the co-culture release of mediators was significantly above the sum of production by the cells cultured separately. Indeed, TII and AM cells considerably potentiated each others' NO" TNF- $\alpha$, MIP-2, and IL-6 release. However, they did not alter each others' IL-1 $\beta$ production. On the other hand, stimulation of AM/TII transwell co-culture with LPS or silica resulted in an inconsistent profile of responses, which generally consisted of less potentiation, especially upon LPS exposure, compared to basal conditions. The results from the transwell co-culture system can be summarized as follows:

Transwell basal significant potentiation. (True for NO", TNF- $\alpha$, MIP-2 and IL6; not true for IL-1 $\beta$ )

Transwell basal potentiation > Transwell LPS potentiation. (True for NO", TNF- $\alpha$, MIP-2 and IL-1 $\beta$; not true for IL-6) 
Transwell silica potentiation > Transwell LPS potentiation. True for TNF- $\alpha$, MIP-2 and IL-1 $\beta$; not true for IL-6 and NO *

Although TII/AM transwell potentiated basal NO production, less potentiation was seen for NO production after silica exposure. Therefore, TII/AM interaction can not explain the activation of silica induced NO production in vivo or in vitro after exposure to BAL fluid from silica-exposed rats (Huffman et al., 1998).

2B-Mixed co-culture: In the mixed co-culture system, there was a trend for less potentiation or even significant inhibition of mediator release. TII and AM cells only slightly potentiated each others' TNF- $\alpha$, IL- $1 \beta$ and IL- 6 release. They did not alter each others' MIP-2. They inhibited each others' NO release.

To explain the above mentioned results, we theorized that surfactant released from TII cells is inhibiting cytokine and oxidant release from AM's whenever it's able to reach them. The ability of surfactant and other mediators, namely TNF- $\alpha$, to diffuse through the transwell was measured. The results showed that TNF- $\alpha$ was able to freely diffuse across the transwell filter. However, free diffusion of surfactant was inhibited by approximately $80 \%$ by the presence of the transwell filter between the bottom well and the insert. Thus, when the 2 cell types are in direct contact as in the mixed co-culture system, surfactant's effects on AM's are more apparent compared to when the cells are separated by the transwell filter. Other investigators have supported this theory. Indeed, Miles et al. (1999) has shown that surfactant inhibits AM responsiveness to LPS. Also, for our theory to stand, it has to be clarified that TII cells are able to secrete surfactant in culture and that AM's are able to engulf all the released surfactant in our experimental setting. Indeed, Mason et al. (1980) have shown that primary TII cells in culture are able 
to synthesize saturated phospatidylcholine and phosphatidylglycerol (lipid components in surfactant) linearly for days in culture. Chander et al. (1983) have shown that $0.25 \times 10^{6}$ primary TII cells in vitro can synthesize $\sim 2.5 \mu \mathrm{g} / \mathrm{ml}$ DSPC during a 6-hour incubation period, that would be equivalent to $7.5 \mu \mathrm{g} / \mathrm{ml}$ DSPC during 18 hours, which is the time period of our exposure. In addition, Dobbs et al. (1987) have shown that $\sim 2 \%$ of the synthesized DSPC is secreted by $0.25 \times 10^{6}$ primary TII cells in vitro every 6 hours. So 6 $\%$ would be secreted in 18 hours. $7.5 \times 6 / 100=0.45 \mu \mathrm{g} / \mathrm{ml} \mathrm{DSPC}$ is secreted in our setting. Miles et al. (1988) have shown that $2.4 \mu \mathrm{g} / \mathrm{ml}$ DSPC, which would be much greater than the $0.45 \mu \mathrm{g} / \mathrm{ml}$ DSPC secreted in our setting can be totally internalized in vitro by an AM concentration equivalent to the one we used. Therefore, all the surfactant secreted would be available to the AM's to affect AM secretory activity (Miles et al., 1999). In addition, the lower basal potentiation observed upon adding silica and LPS to the AM/TII transwell co-culture could be explained by the fact that silica and LPS (possibly more than silica) increase surfactant phospholipid release by alveolar TII cells (Porter et al., 2001; Sugahara et al., 1996).

The alveolar lining in a rat lung has been reported to have an average thickness of $\sim 0.2$ $\mu \mathrm{m}$ (Bastacky et al., 1995). The portion of the AM volume in contact with surfactant in vivo is not known and hence the inhibition of AM's by surfactant might or might not be significant in vivo. Therefore, the question of whether an in vitro transwell or mixed $\mathrm{AM} / \mathrm{TII}$ co-culture setting might more closely mimic the in vivo situation is still unanswered.

To support our theory stating that surfactant is an inhibitory mediator released from TII cells and acting on AM's, a surfactant inhibitor, fibrinogen (Seeger et al., 1993; Gupta et 
al., 2000), was added in the mixed co-culture system. The results showed that the inhibitory effect observed in the basal mixed co-culture system was removed for NO , TNF- $\alpha$, MIP-2, and IL-1 $\beta$ by inhibiting surfactant with fibrinogen. Preliminary control studies indicate that fibrinogen did not stimulate AM's or TII cells separately. Mixed co-culture potentiation < Transwell co-culture potentiation. (True for NO" TNF- $\alpha$ and MIP-2; not true for IL-1 $\beta$ and IL-6)

\section{Fibrinogen (surfactant inhibitor) decreased the mixed basal co-culture inhibition.}

(True for NO" TNF- $\alpha$, MIP-2 and IL-1 $\beta$; not true for IL6)

The above results support the hypothesis that surfactant probably is the inhibitory mediator released from TII cells which acts on AM's, since inhibiting surfactant decreased the significant inhibition in mediator release observed under basal conditions in the AM/TII mixed co-culture compared to transwell co-culture. Therefore, it could be argued that basal transwell co-culture conditions could prove to be very helpful in studying surfactant effects on lung cells.

Whereas lung surfactant seems to have inhibitory effects on AM's, adding Survanta to lung fibroblasts might stimulate IL-6 mRNA production from these cells (personnel communication with Dr Murali Rao). Knowing that surfactant could be in contact with fibroblasts in the case where alveolar TI epithelial cells are damaged and/or dead, cytokine release from $\mathrm{AM} /$ fibroblast intercellular interaction could be very important to investigate.

AM/TII cell interaction could change with the type of cells used, i. e., primary vs. cell line. For example, Tao and Kobzik (2002) reported different results than ours; i. e., they reported an increase in TNF- $\alpha$ and MIP-2 in AM/RLE-6TN mixed co-culture but not in 
transwell co-culture exposed to silica. It could be argued that the contrasting results of Tao and Kobzik (2002) can be explained by their using the RLE-6TN cell line instead of primary TII cells. Indeed, Driscoll et al. (1995a) has shown that RLE-6TN cells produce much less surfactant than primary TII cells. In addition, just like surfactant was reported to differentially regulate chemotaxis of different neutrophil populations (Schagat et al., 2003), it is possible that it interacts differently with different cell types. Indeed, using the macrophage cell line RAW 264. 7 instead of primary AM's resulted in significantly different effects of surfactant on macrophage activity. Indeed, Rao et al. (1999) have shown that Survanta does not inhibit LPS-induced NO production in the macrophage cell line RAW 264. 7, whereas it significantly inhibits NO production by LPS-induced primary AM's (Miles et al., 1999). Rao et al. (2002) also showed that the signaling pathways for NF- $\mathrm{BB}$ activation of various macrophage cell lines upon LPS exposure may differ from primary AM's, supporting that cell lines might not be a good model system. The AM/TII cell interaction also changes with exposure. Indeed, LPS and silica exposures could modify the levels and/or the functions of important mediators in intercellular interactions. For example, LPS and silica increase surfactant levels (Sugahara et al., 1996; Porter et al., 2001). LPS has also been reported to directly interact with surfactant (Kalina et al., 1995; Kuau et al., 1992), which could possibly lead to modification of surfactant functions.

Aim 3: An AM/TII intercellular communication was found to exist and to be significantly highlighted under unstimulated transwell co-culture conditions. Therefore, this part of the study was an attempt to answer the following question: what mediator(s) 
is/are involved in the AM/TII intercellular communication? The answer to this question could help in designing in vitro experiments to be closer to in vivo situations.

Three experimental approaches were taken to try to determine possible intercellular mediators. The first approach was to determine the effect of some inhibitors on the $\mathrm{AM} / \mathrm{TII}$ transwell basal interaction as far as cytokine release is concerned. The second approach was to determine the effect of adding exogenous mediators to AM or TII cell monocultures on the ability of the cell types to release cytokines, and the third approach was to add unstimulated conditioned medium following an 18-hour culture from one cell type onto the other and observe any alteration in cytokine release.

Main results and discussion for aim 3:

3A-Conditioned medium experiments

AM conditioned medium increased cytokine release (TNF- $\alpha$ and MIP-2) from TII meaning that some mediator(s) from AM's could be potentiating TII cell. Indeed, Leslie et al. (1985) reached the same conclusion when AM conditioned medium stimulated DNA synthesis in TII cells. Also, AM conditioned medium has been reported to increase basal IL-6 release from primary TII cells (Crestani et al., 1994). To try to find out if this/those mediators include TNF- $\alpha$ and/or IL-1 $\beta$, antibodies for these mediators were added to the AM conditioned medium before adding it to the TII culture. The results were as follow:

Anti-TNF- $\alpha$ and anti-IL-1 $\beta$ didn't decrease the TII potentiation induced by adding the AM conditioned medium, suggesting that TNF- $\alpha$ and IL- $1 \beta$ might not be the main mediators in the intercellular communication. 


\section{TII conditioned medium didn't increase TNF- $\alpha$ or MIP-2 release from AM's,}

suggesting that no mediator released from TII is influencing TNF- $\alpha$ or MIP-2 release from AM's.

3B-Mediator experiments (done on the AM's or TII cells separately): Mediators used were exogenous TNF- $\alpha$, IL-1 $\beta, \mathrm{H}_{2} \mathrm{O}_{2}$, PGE2 and LTB4

Hydrogen peroxide $\left(\mathrm{H}_{2} \mathrm{O}_{2}\right)$ : As mentioned earlier, $\mathrm{H}_{2} \mathrm{O}_{2}$ is an important ROS. When cells like AM's and TII respond to a stimulant, high levels of ROS can be generated that may overwhelm the cells' antioxidant capacity and cause oxidative stress. ROS can cause direct cell damage by oxidizing lipids (Dalal et al., 1990), proteins, carbohydrates, and DNA which confer to ROS a microbicidal and tumoricidal role (Johnston, 1978). They can also cause indirect cell and /or tissue damage by inducing cellular production of other pro-inflammatory mediators, such as TNF- $\alpha$, MIP-2, IL-1 $\beta$, IL-6 and other mediators regulated by NF- $\kappa \mathrm{B}$ and AP-1 nuclear transcription factors (Comhair and Erzurum, 2002). In the present study, exogenous $\mathrm{H}_{2} \mathrm{O}_{2}$ (Shi et al., 1999), was added to the culture medium of separate cell types in order to assess role of oxidants on each cell type and thus see if oxidants are potential mediators in AM/TII cell interaction.

Tumor necrosis factor-alpha (TNF- $\alpha)$ : TNF- $\alpha$ is a very important inflammatory cytokine synthesized as an early response mediator in cellular stimulation (Martin, 1999). It's a mediator in the recruitment and activation of inflammatory cells, cell proliferation, and extracellular matrix protein synthesis (Driscoll, 1996 b). It can stimulate the production of other pro-inflammatory cytokines, such as MIP-2 (Driscoll et al., 1996 a; Barrett et al., 1999 a) and IL-6 (Crestani et al., 1994), and oxidant species, such as ROS and NO ,

through the activation of NF-אB (Driscoll et al., 2001; Barrett et al., 1999 a), and/or other 
cellular components. In our study, exogenous TNF- $\alpha$ protein (Crestani et al., 1994), was added to the culture medium of separate cell types (AM's or TII cells) in order to assess its role on each cell type and thus see if it could be a mediator in the AM/TII cell interaction.

Interleukin-1beta (IL-1 $\beta)$ : IL-1 $\beta$ is an early response pro-inflammatory cytokine with many similar effects as TNF- $\alpha$, such as recruitment and activation of inflammatory cells, cell proliferation, extracellular matrix protein synthesis and induction of other proinflammatory cytokines. In the present study, exogenous IL-1 $\beta$ protein (Crestani et al., 1994), was added to the culture medium of separate cell types (AM's or TII cells) in order to assess its role on each cell type and thus see if it could be a mediator in the AM/TII cell interaction.

Leukotrienes and prostaglandins: They are products of the breakdown of arachidonic acid (a cell membrane component) by lipoxygenase (LO) and cyclo-oxygenase (CO) enzymes, respectively. Leukotrienes and prostaglandins are generally associated with increased inflammation, including chemotaxis and inflammatory cytokine production (Dubois et al., 1989). In the our study, exogenous $\mathrm{LTB}_{4}$ or $\mathrm{PGE}_{2}$ (Christman et al., 1991), were added to the culture medium of separate cell types (AM's or TII cells) in order to assess their role on each cell type and see if either one could be a mediator in the AM/TII cell interaction.

Out of all the exogenous mediators added to separate AM or TII cell cultures, only TNF- $\alpha$ added to AM's stimulated cytokine release (MIP-2). These results show that TNF- $\alpha$ is a stimulant for AM's. But since the TII conditioned medium on AM's results suggested that MIP-2 does not increase in AM's following the addition of TII 
conditioned medium, it could be argued that TNF- $\alpha$ level released from TII cells is not enough to potentiate MIP-2 release from AM's, and that maybe an additional source of TNF- $\alpha$ is needed for AM MIP-2 potentiation in vivo. As for the effect of exogenous TNF- $\alpha$ on TII cells, although our results suggest that this mediator does not potentiate MIP-2 release from TII cells, a study by Koyama et al. (1999) that measured different end points following TNF- $\alpha$ addition to a TII-like cell line (A549) found significant stimulation. Indeed, Koyama et al. have reported an increase in monocyte chemoattractant protein-1 (MCP-1) and $\mathrm{LTB}_{4}$ from A549 following TNF- $\alpha$ addition. In addition, whereas use of exogenous $\mathrm{H}_{2} \mathrm{O}_{2}$ in our study did not induce an increase in TNF$\alpha$ or MIP-2 from AM's or TII cells (cultured separately), Shi et al. (1999) have reported that $\mathrm{H}_{2} \mathrm{O}_{2}$ induced an increase in MIP-2 mRNA from an NR 8383 rat AM cell line. The discrepancy of the above results could be explained by the fact that Shi et al. (1999) have used a cell line instead of primary AM's, which could very well have different responses than primary cells, as was demonstrated earlier. As for the results in the present study showing that exogenous IL-1 $\beta$ did not stimulate TNF- $\alpha$ or MIP-2 release from AM's or from TII cells, these data certainly do not mean that IL-1 $\beta$ does not stimulate AM's or TII cells in general. Indeed, Standiford et al. (1990) have measured different end points upon adding exogenous IL-1 $\beta$ and found significant stimulation such as an increase in IL-8 from an A549 TII-like cell line. Furthermore, Punjabi et al. (1994) reported an induction of NO release in TII cells, and Yang et al. (1999) showed an increase in TII DNA synthesis following IL-1 $\beta$ addition. Finally, although our data with mediator addition report no stimulation of TNF- $\alpha$ or MIP-2 release from AM's or TII cells upon $\mathrm{PGE}_{2}$ or $\mathrm{LTB}_{4}$ addition, they do not mean that prostaglandins or leukotrienes do not 
stimulate AM's or TII cells in general. Indeed, Fournier et al. (1999) have reported an increase in alpha 1-acid glycoprotein (AGP), which is induced during pulmonary inflammation, upon adding $\mathrm{PGE}_{2}$ to AM's in vitro. Also, whereas Christman et al. (1991) have shown an increase in chemotactic activity in AM's in vitro upon adding LTB4, they reported a suppression of the chemotactic activity by adding PGE2 to endotoxin-stimulated AM's. It appears, therefore, that the response to mediator treatmentdepends on both the cell types studied and the end point measured. 3C-Inhibitors experiments (done in AM/TII transwells under basal conditions): Different inhibitors were added to the AM/TII transwell medium to assess the role of the inhibited substance on $\mathrm{AM} / \mathrm{TII}$ interaction and thus try to see if the inhibited substance is/are mediator(s) in AM/TII intercellular communication. Inhibitors used were: NAC(nonspecific antioxidant (Kang et al., 2000)), Vitamin C(non-specific antioxidant (Chen et al., 1998)), SOD(superoxide inhibitor (Li et al., 1999)), catalase (hydrogen peroxide inhibitor (Li et al., 1999)), NDGA (lipoxygenase inhibitor (Dubois et al., 1989)), indomethacin (cycloxygenase inhibitor (Peden et al., 1984)), anti-TNF- $\alpha$ (TNF- $\alpha$ neutralizing antibody (Barrett et al., 1998)), and anti-IL-1 $\beta$ (IL-1 $\beta$ neutralizing antibody (Yang et al., 1999)) All inhibitors significantly decreased AM/TII transwell basal potentiation. These results suggest that oxidants, TNF- $\alpha$, IL1 $\beta$, prostaglandins and leukotrienes, somehow contribute in the pathway of AM/TII intercellular communication.

\section{Conclusions:}

After having compared the release of several inflammatory mediators from AM's, TII, and RLE-6TN cells and different AM/TII co-culture settings under the same culture 
conditions, same exposures (basally, or following LPS or silica exposures) and same cell concentrations, the following statements could be safely stated:

1) Although AM's were generally found to release more inflammatory mediators than TII cells following LPS or silica exposures, TII cells clearly produced significant levels of mediators which could be capable of contributing considerably to lung inflammation and injury.

2) Since the RLE-6TN TII cell line responses to LPS and silica exposures were generally considerably less intense and required higher doses of stimulant than those measured in primary TII cells, RLE-6TN cells may not be a good substitute for primary TII cells in studying the pulmonary epithelium.

3) LPS was found to be a more potent inducer of inflammatory cytokines from AM's, TII, and RLE-6TN cells. However, silica was found to be as potent as LPS or even slightly more potent as an inducer of cellular oxidants, especially from TII cells.

4) Surfactant appears to be an inhibitory mediator released from TII cells and acting on AM's.

5) Basal transwell co-culture conditions are better than mixed co-culture conditions to study AM/TII cell interactions since the inhibitory effect of the surfactant in the transwell co-culture is minimized.

6) AM/TII cell interaction is very specific for the cell type used, (i. e., primary vs. cell line) and for exposure conditions, among other factors.

7) Oxidants, TNF- $\alpha$, IL1 $\beta$, prostaglandins and leukotrienes, probably do not directly affect the AM/TII intercellular interaction; instead, they (and especially TNF- $\alpha$ ) appear to indirectly modulate the complex pathway(s) of the AM/TII communication. 


\section{$\underline{\text { References }}$}

Askin, F. B. and Kuhn, C. The cellular origin of pulmonary surfactant. Lab. Invest. $1971 ; 25(3): 260-8$

Babior, B. M. The production and use of reactive oxidants by phagocytes. In: Reactive oxygen species in biological systems: an interdisciplinary approach. D. L. Gilbert and C. A. Colton (eds). Kluwer academic/ Plenum publishers. New York, 1999. 503-526 Banks, M. A., Martin, W. C., Pailes, W. H. and Castranova, V. Taurine uptake by isolated alveolar macrophages and type II cells. J. Appl. Physiol. 1989; 66(3): 10791086

Barrett, E. G., Johnston, C., Oberdorster, G. and Finkelstein, J. N. Silica-induced chemokine expression in alveolar type II cells is mediated by TNF- $\alpha$. Am. J. Physiol. 1998; 275: L1110-L1119

Barrett, E. G., Johnston, C., Oberdorster, G., and Finkelstein, J. N. Silica-induced chemokine expression in alveolar type II cells is mediated by TNF- $\alpha$-induced oxidant stress. Am. J. Physiol. 1999 a; 276: L979-L988

Barrett, E. G., Johnston, C., Oberdorster, G. and Finkelstein, J. N. Antioxidant treatment attenuates cytokine and chemokine levels in murine macrophages following silica exposure. Toxicol. Appl. pharmacol, 1999 b; 158: 211-220

Bastacky, J., Lee, C. Y. C., Goerke, J., Koushafar, H., Yager, D., Kenaga, L., Speed, T. P., Chen, Y., and Clements, J. A. Alveolar lining layer is thin and continuous: lowtemperature scanning electron microscopy of rat lung. J. Appl. Physiol. 1995; 79(5):1615-1628

Bissonnette, E., Carre, B., Dubois, C. and Rola-Pleszczynski, M. Inhibition of alveolar macrophage cytotoxicity by asbestos: possible role of prostaglandins. J. Leukocyte Biol. 1990; 47: 129-134

Blackford, J. A. Jr., Antonini, J. M., Castranova, V. and Dey, R. D. Intratracheal instillation of silica up-regulates inducible nitric oxide synthase gene expression and increases nitric oxide production in alveolar macrophages and neutrophils. Am. J. Resp. Cell. Mol. Biol. 1994; 11(4): 426-31

Blau, H., Riklis, S., Kravtsov, V. and Kalina, M. Secretion of cytokines by rat alveolar epithelial cells: possible regulatory role for SP-A. Am. J. Physiol. 1994; 266: L148L155

Burrell, R. Bacterial endotoxin. In: Comprehensive Toxicology - Toxicology of the Respiratory System, Vol 8 ( Roth RA, ed). New York: Elsiever Press, 1997; 611-628 
Calvano, J. E., Agnese, D. M., Um, J. Y., Goshima, M., Singhal, R., Coyle, S. M., Reddell, M. T., Kumar, A., Calvano, S. E., and Lowry, S. F. Modulation of the lipopolysaccharide receptor complex (CD14, TLR4, MD-2) and toll-like receptor 2 in systemic inflammatory response syndrome-positive patients with and without infection relationship to tolerance. Shock. 2003; 20(5): 415-9

Castranova, V., Bowman, L., Reasor, M. and Miles, P. Effects of heavy metal ions on selected oxidative metabolic processes in rat alveolar macrophages. Toxicol. Appl. pharmacol, 1980; 53: 14-23

Castranova, V., Wright, J. R., Colby, H. D. and Miles, P. R. Ascorbate uptake by isolated rat alveolar macrophages and type II cells. J. Appl. Physiol. : Respirat. Environ. Exercise Physiol. 1983; 54 (1): 208-214

Castranova, V., Rabovsky, J., Tucker. J. H. and Miles, P. R. The alveolar Type II epithelial cell: a multifunctional pneumocyte. Toxicol. Appl. pharmacol, 1988; 93: 472483

Castranova, V., Jones, T. A., Barger, M. W., Afshari, A., and Frazer, D. G. Pulmonary responses of guinea pigs to consecutive exposures to cotton dust. Proceedings of the $14^{\text {th }}$ Cotton Dust Research Conference. National Cotton Council. 1990; 131-135

Castranova, V. Generation of oxygen radicals and mechanisms of injury prevention. Env. Health Persp. 1994; 102 (suppl. 10): 65-8

Castranova, V. Particulates and the airways: Basic biological mechanisms of pulmonary pathogenicity. Appl. Occup. Environ. Hyg. 1998; 13(8):613-616

Castranova, V. From coal mine dust to quartz: mechanisms of pulmonary pathogenicity. Inhal. Tox. 2000 a; 12(Suppl. 3):7-14

Castranova, V. and Vallyathan, V. Silicosis and coal workers' pneumoconiosis. Environ. Health Perspect. 2000 b: 108(Suppl. 4): 675-683

Castranova, V., Ma, J. Y. C., Yang, H. M., Antonini, J. M., Butterworth, L., Barger, M. W., Roberts, J., and Ma, J. K. H. Effect of exposure to diesel exhaust particles on the susceptibility of the lung to infection. Environ. Health Perspect. 2001: 109(Suppl. 4): $609-612$

Chandel, N. S., Trzyna, W. C., McClintock, D. S and Schumacker, P. T. Role of oxidants in NF-kappa B activation and TNF-alpha gene transcription induced by hypoxia and endotoxin 
Chander, A., Dodia, C. R., Gil, J. and Fisher, A. B. Isolation of lamellar bodies from rat granular pneumocytes in primary culture. Biochim. Biophys. Acta. 1983; 753: 119-129

Chen, F.,Sun, S. C., Kuh, D. C., Gaydos, L. J. and Demers, L. M. Essential role of NF$\kappa \mathrm{B}$ activation in silica-induced inflammatory mediator production in macrophages.

Biochem. Biophys. Res. Communications. 1995; 214 (3): 985-992

Chen, F., Lu, Y., Demers, L. M., Rojanasakul, Y., Shi, X., Vallyathan, V. and Castranova, V. Role of hydroxyl radical in silica-induced NF-kB activation in macrophages. Ann. Clin. Lab. Sci. 1998; 28 (1): 1-13

Chen, F., Demers, L. M. and Shi, X. Upstream signal transduction of NF- $\mathrm{kB}$ activation. Current Drug Targets- Inflammation \& Allergy. 2002; 1: 137-149

Chen, F. and Castranova, V. Reactive oxygen species in the activation and regulation of intracellular signaling events. In: Reactive oxygen/nitrogen species: Lung injury and disease. V. Vallyathan, X. Shi, and V. Castranova (eds). Marcel Dekker, New York, 2004. $59-90$

Christman, J. W., Christman, B. W., Shepherd, V. L., and Rinaldo, J. E. Regulation of alveolar macrophage production of chemoattractants by leukotriene B4 and prostaglandin E2. Am. J. Resp. Cell Mol. Biol. 1991; 5(3):297-304

Christman, J. W., Lancaster, L. H. and Blackwell, T. S. Nuclear factor $\kappa$ B: a pivotal role in the systemic inflammatory response syndrome and new target for therapy. Intensive Care Med. 1998; 24: 1131-1138

Clements, J. A. Surface tension of lung extracts. Proc. Soc. Exp. Biol. 1957; 95: 170172

Clements, J. A. Functions of the alveolar lining. Am. Rev. Respir. Dis. 1977; 115(6): 67-71

Comhair, S. A. and Erzurum, S. C. Antioxidant responses to oxidant-mediated lung diseases. Am. J. Physiol. Lung Cell. Mol. Physiol . 2000; 283: L246-L255

Crapo, J. D., Young, S. L., Fram, E. K., Pinkerton, K. E., Barry, B. E. and Crapo, R. O. Morphometric characteristics of cells in the alveolar region of mammalian lungs. Am. Rev. Respir. Dis. 1983; 128: S42-S46

Crestani, B., Cornillet, P., Dehoux, M., Rolland, C., Guenounou, M., Aubier, M. Alveolar type II epithelial cells produce interleukin-6 in vitro and in vivo: regulation by alveolar macrophage secretory products. J. Clin. Invest. 1994; 94(2):731-740 
Crippen, T. L., Klasing, K. C. and Hyde, D. M. Cytokine-induced neutrophil chemoattractant production by primary rat alveolar type II cells. Inflammation. 1995; 19(5): 575-586

Dalal, N. S., Shi, X. L. and Vallyathan, V. Role of free radicals in the mechanisms of hemolysis and lipid peroxidation by silica: comparative ESR and cytotoxicity studies. $J$. Tox. Env. Health. 1990; 29(3):307-16

Dobbs, L. G., Gonzalez, R., and Williams, M. C. An improved method for isolation of type II cells in high yield and purity. Am. Rev. Respir. Dis. 1986; 134: 141-145

Donaldson, K. and Tran, C. L. Inflammation caused by particles and fibers. Inh. Tox. 2002; $14: 5-27$

Driscoll, K. E., Lindenschmidt, R. C., Maurer, J. K., Higgins, J. M and Ridder, G. Pulmonary response to silica or titanium dioxide: inflammatory cells, alveolar macrophage-derived cytokines, and histopathology. Am. J. Respir. Cell Mol. Biol. 1990; 2: 381-390

Driscoll, K. E. Macrophage inflammatory proteins: biology and role in pulmonary inflammation. Exp. Lung Res. 1994; 20(6): 473-90

Driscoll, K. E., Carter, J. M., Iype, P. T., Kumari, H. L., Crosby, L. L., Aardema, M. J., Isfort, R. J., Cody, D., Chestnut, M. H., Burns, J. L and Leboeuf, R. A. Estasblishment of immortalized alveolar type II epithelail cell line from adult rats. In vitro Cell. Dev. Biol. Anim. 1995 a; 31:516-527

Driscoll, K. E., Hassenbein, D. G., Carter, J. M., Kunkel, S. L., Quinlan, T. R. and Mossman, B. T. TNF- $\alpha$ and increased chemokine expression in rat lung after particle exposure. Toxicology Letters. 1995 b; 82/83: 483-489

Driscoll, K. E., Howard, B. W., Carter, J. M., Asquith, T., Johnston, C., Detilleux, P., Kunkel, S. L. and Isfort, R. J. $\alpha$-Quartz-induced chemokine expression by rat lung epithelial cells. Am. J. Pathol. 1996 a; 149 (5): 1627-1637

Driscoll, K. E. The role of interleukin-1 and tumor necrosis factor a in the lung's response to silica. Silica and silica-induced lung disease. (V. Castranova, V. Vallyathan and W. E. Wallace, Eds. CRC Press, Boca Raton,FL). 1996 b; 163-184

Driscoll, K. E., Deyo,L. C., Carter, J. . M., Howard, B. W., Hassenbein, D. G. and Bertram, T. A. Effects of particle exposure and particle-elicited inflammatory cells on mutation in rat alveolar epithelial cells. Carcinogenesis. 1997; 18(2):423-30

Driscoll, K. E., Carter, J. M., Howard, B. W., Hassenbein, D., Janssen, Y. M. and Mossman, B. T. Crocidolite activates NF-kappa B and MIP-2 gene expression in rat 
alveolar epithelial cells. Role of mitochondrial-derived oxidants. Env. Health Persp. 1998; 106 (suppl. 5): 1171-4

Driscoll, K. E., Howard, B. W., Carter, J. M., Janssen, Y. M., Mossman, B. T., and Isfort, R. J. Mitochondrial-derived oxidants and quartz activation of chemokine gene expression. Adv. Exp. Med. Biol. 2001; 500: 489-496

Drumm, K., Messner, C. and Kienast, K. Reactive oxygen intermediate-release of fibreexposed monocytes increases inflammatory cytokine-mRNA level, protein tyrosine kinase and NF-кB activity in co-cultured bronchial epithelial cells (BEAS-2B). Eur. J. Med. Res. 1999; 4: 257-263

Dubois, C. M., Bissonnette, E. and Rola-Pleszczynski, M. Asbestos fibers and silica particles stimulate rat alveolar macrophages to release tumor necrosis factor. Am. Rev. Respir. Dis. 1989; 139: 1257-1264

Finkelstein, J. N. Physiologic and toxicologic responses of alveolar type II cells. Toxicology. 1990; 60(1-2):41-52

Finkelstein, J. N., Johnston, C., Barrett, E. G. and Oberdorster, G. Particulate-cell interactions and pulmonary cytokine expression. Environ. Health Perspect. 1997; 105 (Suppl 5): 1179-1182

Fisher, A. B., Furia, L. and Berman, H. Metabolism of rat granular pneumocytes isolated in primary culture. J. Appl. Physiol. : Respirat. Environ. Exercise Physiol. 1980; 49(4): 743-750

Fournier, T., Bouach, N., Delafosse, C., Crestani, B., and Aubier, M. Inducible expression and regulation of the alpha 1-acid glycoprotein gene by alveolar macrophages: prostaglandin E2 and cyclic AMP act as new positive stimuli. J. Immunology. 1999; 163(5):2883-90

Gupta, M., Hernandez-Juviel, J. M., Waring, A. J., Bruni, R. and Walther, F. J. Comparison of functional efficacy of surfactant protein B analogues in lavaged rats. Eur. Respir. J. 2000; 16: 1129-1133

Haddad, J. J., Safieh-Garabedian, B., Saade, N. E., and Lauterbach, R. Inhibition of glutathione-related enzymes augments LPS-mediated cytokine biosynthesis: involvement of an IkappaB/NF-kappaB-sensitive pathway in the alveolar epithelium. International Immunopharmacology. 2002; 2(11):1567-83

Hahon, N. and Castranova, V. Interferon production in rat type II pneumocytes and alveolar macrophages. Experimental Lung Res. 1989; 15: 429-445 
Haies, D. M., Gil, J. and Weibel, E. R. Morphometric study of rat lung cells. Am. Rev. Respir. Dis. 1982; 123:533-541

Hallman, M., Gkumoff, V. and Ramet, M. Surfactant in respiratory distress syndrome and lung injury. Comparative Biochemistry \& Physiology. Part A, Molecular and Integrative Physiology. 2001; 129 (1): 287-294

Hirano, S. Interaction of rat alveolar macrophages with pulmonary epithelial cells following exposure to lipopolysaccharide. Arch. Toxicol. 1996; 70: 230-236

Huffman, L. J., Judy, D. J. and Castranova, V. Regulation of nitric oxide production by rat alveolar macrophages in response to silica exposure. J. Tox. Env. Health, Part A. 1998; 53: 29-46

Hybertson, B. M., Lee, Y. M., Cho., H. G., Cho, O. J., and Repine, J. E. Alveolar type II cell abnormalities and peroxide formation in lungs of rats given IL-1 intratracheally.

Inflammation. 2000. 24(4):289-303

Iyer, R., Hamilton, R. F., Li, L. and Holian, A. Silica-induced apoptosis mediated via scavenger receptor in human alveolar macrophages. Tox. Appl. Pharmacol. 1996; 141: 84-92

Johansson, A., Lundborg, M., Skold, C. M., Lundahl, J., Tornling, G., Eklund, A. and Camner, P. Functional, morphological, and phenotypical differences between rat alveolar and interstitial macrophages. Am. J. Respir. Cell Mol. Biol. 1997; 16:582-588

Johnston, R. B. Jr. Oxygen metabolism and the microbicidal activity of macrophages. Federation Proc. 1978; 37: 2759-2764

Jones, K. G., Holland, J. F., Fourman, G. L., Bend, J. R. and Fouts, J. R. Xenobiotic metabolism in clara cells and alveolar type II cells isolated from lungs of rats treated with beta-naphthoflavone. J. Pharmacol. Exp. Ther. 1983; 225: 316-319

Jones, J. S., Miles, P. R., Lantz, R. C., Hinton, D. E. and Castranova, V. Ionic content and regulation of cellular volume in rat alveolar type II cells. J. Appl. Physiol. :

Respirat. Environ. Exercise Physiol. 1982; 53(1): 258-266

Jorens, P. G., Vermeine, P. A. and Herman, A. G. L-arginine-dependent nitric oxide synthase: a new metabolic pathway in the lung and airways. Eur. Respir. J. 1993; 6: 258-266

Kaku, M., Yagawa, K. and Tanaka, A. Enhanced superoxide anion release from phagocytes by muramyl dipeptide or lipopolysaccharide. Infection \& Immunity. 1983; 39 (2):559-64 
Kalina, M., Blau, H., Riklis, S., and Kravtsov, V. Interaction of surfactant protein A with bacterial lipopolysaccharide may affect some biological functions. Am. J. Physiol.

1995; 268(1 Pt 1): L144-51

Kang, J. L., Go, Y. H., Hur, K. C. and Castranova, V. Silica-induced nuclear factor-кB activation: involvement of reactive oxygen species and protein tyrosine kinase activation. J. Tox. Env. Health, Part A. 2000; 60: 27-46

Kawanami, O., Jiang, H. X., Mochimaru, H., Yoneyama, H., Kudoh, S., Ohkuni, H., Ooami, H. and Ferrans, V. J. Alveolar fibrosis and capillary alteration in experimental pulmonary silicosis in rats. Am. J. Respir. Crit. Care Med. 1995; 151: 1946-55

Kelley, J. Cytokines of the lung. Am. Rev. Respir. Dis. 1990; 141: 765-788

Kobzik, L. Lung macrophage uptake of unopsonized environmental particulates. Role of scavenger-type receptors. J. Immunol. 1995; 155(1): 367-76

Koyama, S., Sato, E., Nomura, H., Kubo, K., Miura, M., Yamashita, T., Nagai, S., and Izumi, T. Monocyte chemotactic factors released from type II pneumocyte-like cells in response to TNF-alpha and IL-1alpha. Eur. Resp. J. 1999; 13(4):820-8

Kuan, S. F., Rust, K., Crouch, E. Interactions of surfactant protein D with bacterial lipopolysaccharides. Surfactant protein D is an Escherichia coli-binding protein in bronchoalveolar lavage. J. Clin. Inves. 1992; 90(1):97-106

Leslie, C. C., McCormick-Shannon, K., Cook, J. L. and Mason, R. Macrophages stimulate DNA synthesis in rat alveolar type II cells. Am. J. Respir. Dis. 1985; 132: $1246-1252$

Li, Yunbo, Zhu, H. and Trush, M. A. Detection of mitochondria-derived reactive oxygen species production by the chemilumigenic probes lucigenin and luminol. Biochimica Biophysica Acta. 1999; 1428:1-12

Lohmann-Matthes, M-L., Steinmuller, C. and Franke-Ullmann, G. Pulmonary macrophages. Eur. Respir. J. 1994; 7: 1678-1689

Martin, T. R. Lung cytokines and ARDS. Chest. 1999; 116: 2S-8S

Mason, R. J. and Williams, M. C., Identification of type II alveolar cells with phosphine 3R. Am. Rev. Respir. Dis. 1976; 113(4) (suppl. ):47

Mason, R. J and Dobbs, L. G. Synthesis of phosphatidylcholine and phosphatidylglycerol by alveolar type II cells in primary culture. J. Biol. Chem. 1980; 255(1): 5101-5107 
Mason, R. J., Williams, M. C., Widdicombe, J. H., Sanders, M. J., Misfeldt, D. S. and Berry, L. C. Jr. Transepithelial transport by pulmonary alveolar type II cells in primary culture. Proc. Nat. Acad. Sci. U. S. A. 1982; 79(19): 6033-7

McRitchie, D. I., Isowa, N., Edelson, J. D., Xavier, A. M., Cai, L., Man, Heng-Ye, Wang, Y. T., Keshavjee, S. H., Slutsky, A. S. and Liu, M. Production of tumor necrosis factor $\alpha$ by primary cultured rat alveolar epithelial cells. Cytokine. 2000; 12(6):644-654

Miles, P. R., Castranova, V., and Lee, P. Reactive forms of oxygen and chemiluminescence in phagocytizing rabbit alveolar macrophages. Am. J. Physiol. 1978; 235: C103-C108

Miles, P. R., Ma, J. Y. C. and Bowman, L. Degradation of pulmonary surfactant disaturated phosphatidylcholines by alveolar macrophages. J. Appl. Physiol. 1988; 64 (6): $2474-2481$

Miles, P. R., Bowman, L., Rao, K. M. K., Baatz, J. E. and Huffman, L. Pulmonary surfactant inhibits LPS-induced nitric oxide production by alveolar macrophages. Am. J. Physiol. 1999; 276: L186-L196

Nielson, G. D., Alarie, Y., Poulson, O. M. and Nexo, B. A. Possible mechanisms for the respiratory tract effects of noncarcinogenic indoor-climate pollutants and bases for their risk assessment. Scand. . J. Work Environ. Health. 1995; 21: 165-78

O’Neil, S., Lesperance, E. and Klass, D. Rat lung lavage surfactant enhances bacterial phagocytosis and intracellular killing by alveolar macrophages. Am. Rev. Respir. Dis. 1984; 130: 225-230

Panos, R. J., Suwabe, A., Leslie, C. C. and Mason, R. J. Hypertrophic alveolar type II cells from silica-treated rats are committed to DNA synthesis in vitro. Am. J. Respir. Cell Mol. Biol. 1990; 3(1): 51-9

Peden, D., Van Dyke, K., Edinboro, L., Wierda, D. and Castranova, V. The measurement of chemiluminescence, aggregation, and 5-hydroxy-6,8,11,14eicosatetraenoic acid production of n-formyl-methioninyl-leucyl-phenylalaninestimulated human polymorphonuclear leukocytes. Microchemical J. 1985; 31:22-28

Peters, J. M. Silicosis. In: Occupational respiratory diseases. J. A. Merchant (ed). Publication No. DHHS (NIOSH) 86-102, 1987. 219-235

Piguet, P. F., Collart, M. A., Grau, G. E., Sappino, A. P. and Vassalli, P. Requirement of tumor necrosis factor for development of silica-induced pulmonary fibrosis. Nature. 1990; 344: 245-247

Porter, D. W., Ramsey, D., Hubbs, A. F., Battelli, L., Ma, J., Barger, M., Landsittel, D., Robinson, V., McLaurin, J., Khan, A., Jones, W., Teass, A., and Castranova, V. Time 
course of pulmonary response of rats to inhalation of crystalline silica: histological results and biochemical indices of damage, lipidosis, and fibrosis. J. of Env. Path., Tox. And Onc. 2001; 20 (suppl. 1): 1-14

Porter, D. W., Barger, M., Robinson, V. A., Leonard, S. L., Landsittel, D., and Castranova, V. Comparison of low doses of aged and freshly fractured silica on pulmonary inflammation and damage in the rat. Toxicology. 2002 a; 175: 63-71

Porter, D. W., Millecchia, L., Robinson, V., Hubbs, A. F., Willard, P., Pack, D., Ramsey, D., McLaurin, J., Khan, A., Landsittel, D., Teass, A., and Castranova, V. Enhanced nitric oxide and reactive oxygen species production and damage after inhalation of silica. Am.

J. Physiol. Lung Cell. Mol. Physiol. 2002 b; 283: L485-L493

Punjabi, C. J., Laskin, J. D., Pendino, K. J., Goller, N. L., Durham, S. K. and Laskin, D. L. Production of nitric oxide by rat type II pneumocytes: increased expression of inducible nitric oxide synthase following inhalation of a pulmonary irritant. J. Respir. Cell Mol. Biol. 1994; 11:165-172

Rao, K. M. K., Bowman, L. and Meighan, T. Survanta does not inhibit nitric oxide (NO) production induced by lipopolysaccharide (LPS) and interferon- $\gamma$ in two macrophage cell lines. FASEB J. 1999; 13: A1150

Rao, K. M. K., Meighan, T. and Bowman, L. Lung surfactant decreases IL-1 $\beta$ and TNF$\alpha$ production at the post transcriptional level in LPS-stimulated alveolar macrophages.

FASEB J. 2000. Abstract 447. 6

Rao, K. M. K., Meighan, T. and Bowman, L. Role of mitogen-activated protein kinase activation in the production of inflammatory mediators: differences between primary rat alveolar macrophages and macrophage cell lines. J. Toxicol. Environ. Health, Part A. 2002; 65: 757-768

Sacks, M., Gordon, J., Bylander, J., Porter, D., Shi, X. L., Castranova, V., Kaczmarczyk, W., Van Dyke, K., and Reasor, M. J. Silica-induced pulmonary inflammation in rats: activation of NF- $\mathrm{BB}$ and its suppression by dexamethasone. Biochem. Biophys. Res. Commun. 1998; 253: 181-184

Saffiotti, U., Daniel, L. N., Mao, Y., Shi, X., Williams, A. O. and Kaighn, M. E. Mechanisms of carcinogenesis by crystalline silica in relation to oxygen radicals. Environ. Health Persp. 1994; 10: 159-63

Sanders, R. L. and Longmore, W. J. Phosphatidylglycerol in rat lung. Comparison of occurrence, composition, and metabolism in surfactant and residual lung fractions.

Biochemistry. 1975; 14(4):835-840 
Schagat, T. L., Wofford, J. A., Greene, K. E., and Wright, J. R. Surfactant protein A differentially regulates peripheral and inflammatory neutrophil chemotaxis. Am. J. Physiol. Lung Cell Mol. Physiol. 2003; 284:L140-L147

Seeger, W., Stohr, G., Wolf, H. R. and Neuhof, H. Alteration of surfactant function due to protein leakage: special interaction with fibrin monomer. J. Appl. Physiol. 1985; 58(2): $326-38$

Seeger, W., Grube, C., Gunther, A. and Schmidt, R. Surfactant inhibition by plasma proteins: differential sensitivity of various surfactant preparations. Eur. Respir. J. 1993; 6: 971-977

Shi, M. M., Chong, I., Godleski, J. J. and Paulauskis, J. D. Regulation of macrophage inflammatory protein- 2 gene expression by oxidative stress in rat alveolar macrophages. Immunology. 1999; 97(2):309-15

Standiford, T. J., Kunkel, S. L., Basha, M. A., Chensue, S. W., Lynch, J. P. $3^{\text {rd }}$, Toews, G. B., Westwick, J. and Strieter, R. M. Interleukin-8 gene expression by a pulmonary epithelial cell line. A model for cytokine networks in the lung. J. Clin. Invest. 1990; 86(6):1945-53

Standiford, T. J., Kunkel, S. L., Greenberger, M. J., Laichalk, L. L. and Strieter, R. M. Expression and regulation of chemokines in bacterial pneumonia. J. Leukocyte Biol. 1996; 59: 24-28

Stober, W. and McClellan, R. O. Pulmonary retention and clearance of inhaled biopersistent aerosol particles: data-reducing interpolation models and models of physiologically based systems. Crit. Rev. Toxicol. 1997; 27(6): 539-598

Stringer, B. and Kobzik, L. Environmental particulate-mediated cytokine production in lung epithelial cells (A549): role of preexisting inflammation and oxidant stress. J. Tox. Env. Health, Part A, 1998; 55: 31-44

Sugahara, K., Iyama, K., Sano, K., Kuroki, Y., Akino, T., and Matsumoto, M. Overexpression of surfactant protein SP-A, SP-B, and SP-C mRNA in rat lungs with lipopolysaccharide-induced injury. Lab. Invest. 1996; 74(1):209-220

Tao, F. and Kobsik, L. Lung macrophage-epithelial cell interactions amplify particlemediated cytokine release. Am. J. Physiol. Lung Cell. Mol. Physiol . 2003; 284(1):L90-99

Tamatania, T., Hattori, K., Iyer, A., Tamatania, K. and Oyasu, R. Hepatocyte growth factor is an invasion /migration factor of rat urothelial carcinoma cells in vitro. Carcinogenesis. 1999; 20 (6): 957-962 
Toga, H., Tobe, T., Ueda, Y., Yang, G. H., Osanai, K., Ishigaki, H., Katsuda, S., Takahashi, K., Ohya, N. Inducible nitric oxide synthase expression and nuclear factorkappaB activation in alveolar type II cells in lung injury. Experimental Lung Research. 2001; 27(6):485-504

Tsuji, C., Minhaz, M. U., Shioya, S., Tanigaki, T. and Nakazawa, H. The importance of polymorphonuclear leukocytes in lipopolysaccharide-induced superoxide anion production and lung injury: ex vivo observation in rat lungs. Lung. 1998; 176(1):1-13

Vallyathan, V., Shi, X. L. Dalal, N. S., Irr, W. and Castranova, V. Generation of free radicals from freshly fractured silica dust. Potential role in acute silica-induced lung injury. Am. Rev. Respir. Dis. 1988; 138(5):1213-9

Vallyathan, V. Generation of oxygen radicals by minerals and its correlation to cytotoxicity. Env. Health Persp. 1994; 102(suppl. 10):111-5

Vallyathan, V. and Shi, X. L. The role of free radicals in occupational and environmental lung diseases. Environ. Health Perspect. 1997; 105 (Suppl. 1): 165-177

Vernooy, J. H., Dentener, M. A., Van Suylen, R. J., Buurman, W. A. and Wouters, E. F. Long-term intratracheal lipopolysaccharide exposure in mice results in chronic lung inflammation and persistent pathology. Am. J. Respir. Cell Mol. Biol. 2002; 26(1): $152-159$

Wallace, W. E. Jr., Vallyathan, V., Keane, M. J. and Robinson, V. In vitro biologic toxicity of native and surface-modified silica and kaolin. J. Tox. Env. Health. 1985; 16(3-4):415-24

Wright, J. R. Clearance and recycling of pulmonary surfactant. Am. J. Physiol. 1990; 259: L1-L12

Yang, G. H., Osanai, K., and Takahashi, K. Effects of interleukin-1 beta on DNA synthesis in rat alveolar type II cells in primary culture. Respirology. 1999; 4(2):139-45

Zeidler, P. C., Roberts, J. R., Castranova, V., Chen, F., Butterworth, L., Andrew, M. E., Robinson, V. A., and Porter, D. W. Response of alveolar macrophages from inducible nitric oxide synthase knockout or wild-type mice to in vitro lipopolysaccharide or silica exposure. J. Toxicol. Environ. Health. A. 2003; 66(11):995-1013

Zhang, Z., Shen, H. M., Zhang, Q. F. and Ong, C. N. Involvement of oxidative stress in crystalline silica-induced cytotoxicity and genotoxicity in rat alveolar macrophages. Env. Res. 2000; 82(3): 245-252

Zhu, S., Manuel, M., Tanaka, S., Choe, N., Kagan, E. and Matalon, S. Contribution of reactive oxygen and nitrogen species to particulate-induced lung injury. Environ. Health Perspect. 1998; 106 (Suppl. 5): 1157-1163 